\author{
Universidade de São Paulo \\ Museu de Arqueologia e Etnologia \\ Programa de Pós-Graduação em Arqueologia
}

\title{
GESTÃO EM PROJETOS DE ARQUEOLOGIA
}

Everson Paulo Fogolari

São Paulo

2007 


\title{
EVERSON PAULO FOGOLARI
}

\section{GESTÃO EM PROJETOS DE ARQUEOLOGIA}

Tese apresentada ao Programa de PósGraduação em Arqueologia, do Museu de Arqueologia e Etnologia da Universidade de São Paulo - USP, como requisito para obtenção do título de Doutor em Arqueologia.

Orientador: Prof. Dr. José Luiz de Morais

\author{
Museu de Arqueologia e Etnografia \\ Universidade de São Paulo \\ São Paulo \\ 2007
}


Para Cleonice, Felipe e Alexandre, amores incansáveis e eternos, que compreenderam, toleraram e amaram os momentos mais difíceis deste trabalho. 


\section{AGRADECIMENTOS}

Escrever uma tese é um desafio que nos propomos com entusiasmo, mas, quando nos deparamos com o limite de tempo e com o desafio da escrita, o medo aparece, e com muita intensidade. Assim, a ação, que antes se expressava pela individualidade, torna-se, no transcorrer dela, uma tarefa coletiva que é registrada pela individualidade de quem a escreve. Por isso, dedico este trabalho a todos aqueles que, de forma direta ou indiretamente, auxiliaram para a sua conclusão.

Ao José Luiz de Morais, que com extrema competência e dedicação me orientou. Sua persistência, capacidade, sensibilidade e respeito para com minhas idéias ajudaram-me a crescer como profissional e como ser humano. Muito obrigado!

A Diretoria da Sociedade de Arqueologia Brasileira - SAB, gestão 2001/2003, José Luiz de Morais, Margarida Davina Andreatta, Marisa Coutinho Afonso, Dilamar Cândida Martins, por entregarem em minhas mãos a coordenação do XII Congresso de Arqueologia da SAB. Muito obrigado !

Aos colegas de Diretoria da Sociedade de Arqueologia Brasileira SAB, gestão 2003/2005, Gilson Rodolfo Martins, André Prous e Paulo Zanettini. Valeu a luta.

Ao Rossano Lopes Bastos pela credibilidade, apoio aos meus posicionamentos e confiança em deixar-me a Coordenação Executiva do XIV Congresso da SAB - Florianópolis SC. Grande Abraço! 
À Deisy de Morais e ao Filipe de Morais, amigos e acolhedores. Muito obrigado!

Aos professores Margarida Andreatta, Pedro Paulo Funari, Saul Milder, e Marisa Coutinho Afonso. Muito obrigado pela paciência e colaboração.

Aos funcionários do MAE Vanusa, Regina e Fabio, pela calma e tolerância. Muito obrigado!

A todos os colegas da turma 2003 e, especialmente, aos amigos André Wagner Oleani, Henrique, Sílvio, Manoel, João Carlos (Piraju), Carlinhos (Piraju) Sandra Medina, Sílvia Piedade, Dária, Paulinho, Viviane, Anecleide e Marise, que a arqueologia uniu e possibilitou o crescimento em grupo. Um grande abraço.

A meus pais, Paulo (in memória) e Olga, minha irmã Valdirene e meus sobrinhos Luan e Bianca, que, mesmo distantes, sempre me apoiaram, orando e compartilhando os problemas e vitórias. Abraços e beijos.

A toda família Dariva - familiares de minha esposa -, que acolheram Cleonice no período da gravidez e no nascimento de nosso segundo pupilo, Alexandre. Serei eternamente grato. Abraços e beijos.

À Universidade Regional Integrada do Alto Uruguai e das Missões - URI - Campus de Erechim, a que, representada pelo seu corpo diretivo, ficam meus agradecimentos, porque com seu apoio este sonho que conquistei poderá ser compartilhado com todos os acadêmicos desta Universidade, que cada dia se torna maior e a expressão de uma região próspera. Muitíssimo obrigado! 


\title{
RESUMO
}

A arqueologia assumiu uma posição de extrema relevância na atualidade e, especialmente, a arqueologia de projetos vinculados aos empreendimentos impactantes ao meio ambiente em razão das exigências da legislação brasileira. Esse crescimento tem favorecido o surgimento de novos projetos e diferentes olhares sobre a ciência arqueológica e o patrimônio cultural brasileiro. Contudo, muitos projetos não conseguem expressar sua eficiência e eficácia não pela falta de vontade dos envolvidos, mas pela dificuldade do processo que os envolvem, quando não pela incapacidade gerencial de tais projetos. Diante disso, o objetivo é demonstrar que a gestão em projetos de arqueologia é o meio que possibilitará um melhor resultado e o sucesso dos projetos arqueológicos. Esta gestão se sustenta nos fundamentos da arqueologia preventiva, com a utilização da técnica de gestão PDCA - P (Plan = Planejar), D $($ Do $=$ Executar $), C$ (Check $=$ Verificar $), A($ Action $=$ Agir $)$ aplicada aos projetos de arqueologia, o que permitirá um envolvimento com a inter e a transdisciplinaridade, proporcionando uma abertura e uma transparência dos projetos de arqueologia. O agir arqueológico tem a função de criar elementos interlocutores ativos, abrindo janelas através dos sentidos, criadores de percepções e conexões com o mundo. E, entender, incluir, organizar, formar, computar significa aprender a fazer redes complexas, dinâmicas e sistêmicas. A gestão nos projetos de arqueologia, quando integradora de múltiplas dimensões do ser humano, é resultante de uma arqueologia reflexiva, que busca uma abordagem mais complexa da ciência arqueológica e amplia as possibilidades de repercussão, compreendida numa perspectiva local e global.

\author{
Palavras-chave: Arqueologia - Gestão - Patrimônio Cultural - Meio Ambiente - \\ Legislação
}




\begin{abstract}
The Archaeology adopted a position of extreme importance nowadays and, especially, the archaeology of projects linked to the impacted enterprises for the environment by reason of exigencies of Brazilian Legislation. That growth has favored the appearance of new projects and different views about the archaeological science and the Brazilian cultural patrimony. However, many projects don't get to express their efficiency and efficacy not for lack of will of the involveds, but by difficulty of the process that envelop them, when not for the management incapacity of such projects. Before this, the objective is to show that the management in archaeology projects is the way that will possibility a better result and the success of archaeological projects. This management is based in the foundation of the preventive archaeology, with the use of the management technique PDCA - ( Plan ), D ( Do ), C ( Check ), A ( Action ) applied to the archaeology projects, what will permit a envelopment with an inter and a transdisciplinariety proportioning an opening and a transparency of the archaeology projects. The Archaeology action has the function of create active interlocutor elements, opening windows through the senses, creators of perceptions and connections with the world. Understand, include, organize, form, compute means to learn how to do complex nets, dynamic and systemic. The management in the archaeology projects when integrant of multiple dimensions of human being, is result of a reflexive archaeology, that look for an approach more complex of the archaeological science and amplify the possibilities of repercussion, understood in a local and global perspective.
\end{abstract}

Keywords: Archaeology, management, cultural patrimony, environment, legislation 


\section{SUMÁRIO}

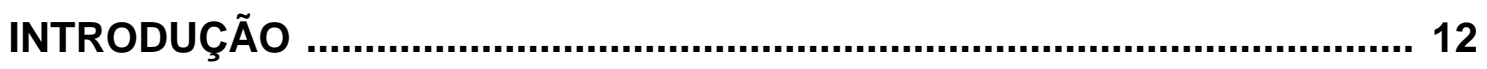

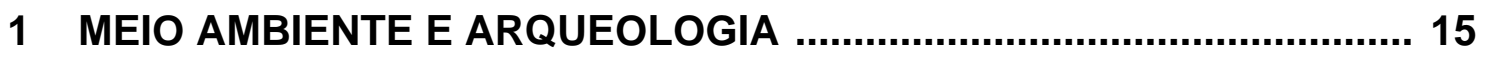

1.10 MEIO AMBIENTE .............................................................. 16

1.2 O MEIO AMBIENTE: UMA VISÃO BRASILEIRA ............................ 20

1.3 O PATRIMÔNIO CULTURAL ...................................................... 34

1.4 RESPONSABILIDADE SOCIAL EM PROL DA ARQUEOLOGIA E DO MEIO AMBIENTE ............................................................. 44

2 LEGISLAÇÃO SOBRE O MEIO AMBIENTE E PATRIMÔNIO

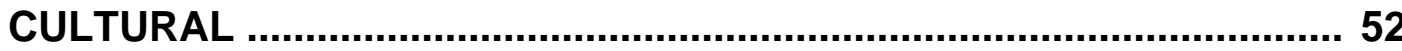

2.1 A PROTEÇÃO DO MEIO AMBIENTE E DO PATRIMÔNIO

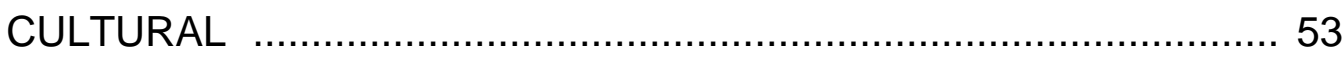

2.2 IMPACTO AMBIENTAL - RESOLUÇÃO CONAMA No. 001 DE 23

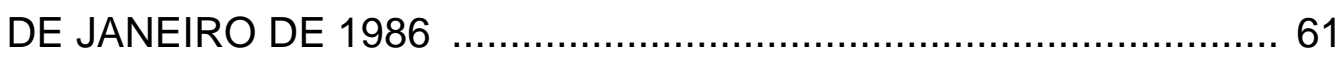

2.3 DIRETRIZES DE CONSERVAÇÃO - PORTARIA SPHAN N No07

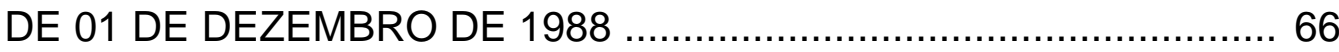

2.4 PROCEDIMENTOS ESSENCIAIS PARA A OBTENÇÃO DE LICENÇA ARQUEOLÓGICA - PORTARIA IPHAN Nº. 230 DE 17 DE

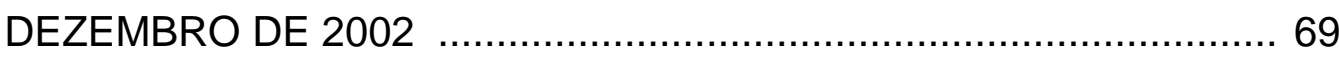

3 ARQUEOLOGIA : DIFERENTES OLHARES …................................... 73

3.1 ARQUEOLOGIA SOB A ÓTICA ACADÊMICA .............................. 74

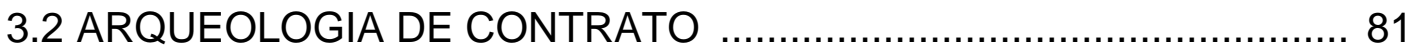

4 GESTÃO: NOÇÕES CONCEITUAIS .................................................... 91

4.1 O QUE É ADMINISTRAÇÃO / GESTÃO …………........................ 92

4.20 PDCA - $P($ PLAN = PLANEJAR $), D(D O=$ EXECUTAR $), \quad C$ $($ CHECK $=$ VERIFICAR $), A(A C T I O N=A G I R) \quad \ldots \ldots \ldots \ldots \ldots \ldots \ldots \ldots \ldots \ldots . . . . . . . . . . . . . . .99$ 
5 ARQUEOLOGIA PREVENTIVA: EXEMPLO DE GESTÃO ….................110

6 A GESTÃO EM ARQUEOLOGIA DE PROJETOS …...........................144

6.10 PDCA - P (PLAN = PLANEJAR $), D(D O=$ EXECUTAR $), \quad C$ $($ CHECK $=$ VERIFICAR $), A(A C T I O N=$ AGIR $)$, APLICADO NA

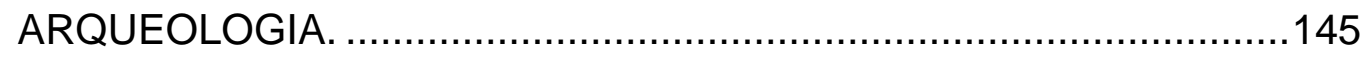

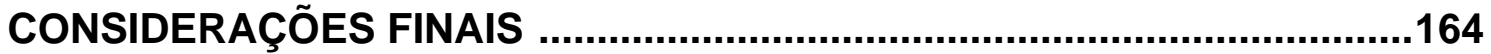

REFERÊNCIAS 


\section{LISTA DE FIGURAS}

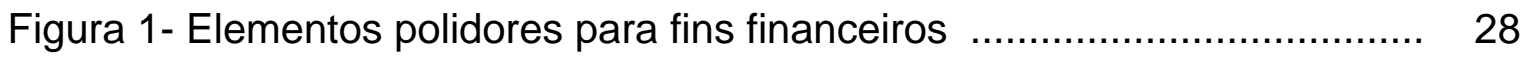

Figura 2 - Desequilíbrio ambiental .................................................. 29

Figura 3 - Depósito de lixo em céu aberto em pequenas comunidades ......... 31

Figura 4 - Energia alternativa (eólica) .......................................... 33

Figura 5 - Projétil encontrado em atividades de campo ........................... 35

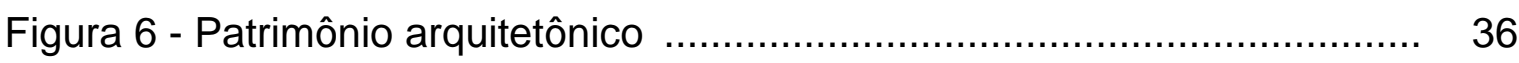

Figura 7 - Elementos de representação da responsabilidade social .............. 47

Figura 8 - O meio ambiente ecologicamente equilibrado ........................... 54

Figura 9 - 14 princípios norteadores da qualidade .................................... 100

Figura 10 - Estrutura do PDCA .................................................... 101

Figura 11- O ciclo do gerenciamento PDCA .......................................... 105

Figura 12 - O esquema da liderança no PDCA ........................................ 106

Figura 13 - Áreas de influência na arqueologia preventiva ......................... 114

Figura 14 - Mapa com áreas de influência .......................................... 115

Figura 15 - Fundamentação conceitual para arqueologia preventiva .............. 119

Figura 16 - Conceitos e definições da arqueologia preventiva (Planejar) ....... 127

Figura 17 - Módulo arqueológico ..................................................... 128

Figura 18 - Conceitos e definições da arqueologia preventiva (Executar) ..... 132

Figura 19 - Núcleos de solo antropogênico ............................................ 133

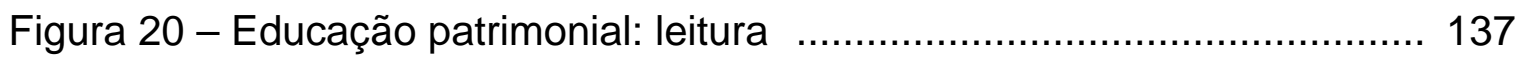

Figura 21 - Educação patrimonial: análise ........................................ 137

Figura 22 - Educação patrimonial: escrita ................................................. 138

Figura 23 - Educação patrimonial: aprender a fazer ................................. 138

Figura 24 - Educação patrimonial: execução .......................................... 139

Figura 25 - Educação patrimonial: resultado da prática ............................. 139

Figura 26 - Educação patrimonial: exposição ....................................... 140

Figura 27 - Fase de obtenção da licença prévia ................................... 147

Figura 28 - Fase de obtenção de licença instalação .................................. 148

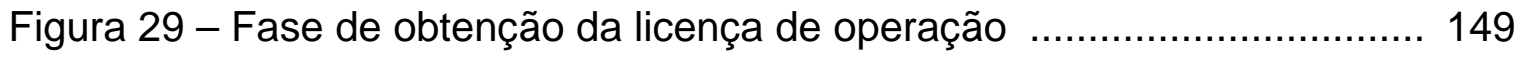


Figura 30 - Diretrizes legais para o licenciamento arqueológico de contrato .. 150

Figura 31 - PDCA aplicável aos projetos de arqueologia - planejar ............... 154

Figura 32 - PDCA aplicável aos projetos de arqueologia - verificar .............. 155

Figura 33 - PDCA aplicável aos projetos de arqueologia - executar ............. 156

Figura 34 - PDCA aplicável aos projetos de arqueologia - agir .................... 157

Figura 35 - A liderança nos projetos de arqueologia .................................. 158

Figura 36 - 14 princípios norteadores da qualidade nos projetos arqueologia. 160 


\section{INTRODUÇÃO}

As mudanças em processos sociais básicos de produção material e nas formas de organização têm sido constantes no mundo contemporâneo. A velocidade dessas mudanças tende a ser confundida com a própria definição da etapa histórica em que se vive. Assim, existir é estar em mudança permanente.

Não se trata mais, em nossos dias, de avaliar as conseqüências determinadas pela criação da máquina a vapor, nem do avião a jato. Agora, mais do que nunca, as mudanças produtivas e as formas de organização social dependem da agregação de conhecimentos, informações e da gestão de processos.

As edificações, a técnica, a ciência e os conhecimentos dos homens tornam-se precários e obsoletos rapidamente se não forem necessários, sérios, consistentes, coerentes, significativos e conscientes, visto que a complexidade do mundo contemporâneo tem atingido várias organizações, em especial as de iniciativa privada, que nos últimos vinte anos têm presenciado uma evolução significativa das técnicas e dos produtos que compõem as ações capitalistas. Essas complexidades têm sido transferidas, também, às instituições que lidam com o conhecimento abstrato e prático.

A busca desse conhecimento, mais do que nunca, está gerando uma aproximação muito maior da iniciativa privada com as universidades, com as ONGs e com o poder público. Indiscutivelmente, as relações dessas instituições têm sido a tônica do momento. Essa relação se pauta pela capacidade de gerenciamento ${ }^{1}$ e gestão, além dos elementos técnico-científicos de cada

\footnotetext{
${ }^{1}$ A forma de gerenciar é variada e assume posicionamentos muito variados em razão das particularidades de cada organização.
} 
instituição. Todavia, em que consistem esses conceitos e quais as aproximações existentes com a ciência arqueológica?

A preservação, a valorização e os investimentos no patrimônio cultural têm sido objeto de vários debates entre os cientistas das ciências sociais e de outras áreas preocupadas com a cultura e com o meio ambiente. Falar sobre gestão em arqueologia de projetos não é tarefa fácil, pois é necessário entender o seu percurso histórico e as vicissitudes que a envolvem. Nesse percurso aparecem diferentes concepções de Gestão em Arqueologia de Projetos e há uma variabilidade de conceitos, não só em razão do seu próprio desenvolvimento, mas também por determinações do tempo e do espaço.

Nesse sentido, reconhecer a importância da gestão em arqueologia de projetos é dimensionar o saber, humanizando as relações entre homens e patrimônio cultural. Dessa forma, retiram-se o ser humano e as organizações do senso comum, oportunizando o homem entender o mundo que o cerca e dele extrair experiências e conhecimentos. Baseado nessa visão, buscou-se estruturar esta tese em seis capítulos, nos quais serão abordados os temas voltados à gestão de projetos de arqueologia e seus respectivos suportes para que ela seja um elemento efetivo e consistente em sua proposição.

"Meio Ambiente e Arqueologia", é o capítulo 1, que busca conceituar o meio ambiente, a arqueologia, o patrimônio cultural e a responsabilidade social, proporcionando uma visão geral dos aspectos legais que envolvem estes temas. É direito da geração presente e das futuras de ter um meio ambiente e um patrimônio protegido e resguardado das agressões do homem inconseqüente.

No capítulo 2, "Legislação sobre o meio ambiente e o patrimônio cultural", apresentam-se as principais normas de proteção ao meio ambiente e ao patrimônio histórico e cultural.

"Arqueologia: Diferentes olhares", no capítulo 3, discorre as diferentes concepções entre arqueologia acadêmica e a arqueologia de contrato. 
No capítulo 4, "Gestão: noções conceituais", desenvolvem-se o conceito de Administração/Gestão, a sua origem na administração científica e a técnica do PDCA $-\mathrm{P}($ Plan = Planejar $), \mathrm{D}($ Do = Executar $), \mathrm{C}($ Check = Verificar $), \mathrm{A}($ Action = Agir) como instrumento de gestão.

O capítulo 5 contempla "Arqueologia Preventiva: um exemplo de gestão", que transita de forma interdisciplinar e transdisciplinar com vistas à preservação do patrimônio arqueológico.

"A gestão em arqueologia de projetos, capítulo 6, trabalha a proposta do Planejar, Executar, Verificar e Agir - PDCA nos projetos de arqueologia".

Posteriormente, esta tese contempla as considerações finais e as referências.

Encerrando o relatório de pesquisa,, tem-se a certeza de que o tema trabalhado, em momento algum, teve a pretensão de ser uma panacéia ou de estabelecer terminologias fechadas, privilegiando $\mathrm{o}$ conhecimento de especialistas; ao contrário, é um estudo que deve ser entendido por todos, conscientizando sobre a necessidade de se ter um meio ambiente sadio e um patrimônio cultural e arqueológico protegido. 


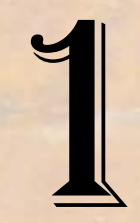

\section{MEIO AMBIENTE E ARQUEOLOGIA}

O Direito do Ambiente é um complexo de princípios e normas coercitivas reguladoras das atividades humanas que, direta ou indiretamente, passam afetar a sanidade do ambiente em sua dimensão global, visando a sua sustentabilidade para as presentes e futuras gerações.

Édis Milaré 


\section{MEIO AMBIENTE E ARQUEOLOGIA}

\subsection{O MEIO AMBIENTE}

A expressão "meio ambiente" carrega várias interpretações, de acordo com em diferentes contextos e, especificamente, com diferentes épocas. A este trabalho não interessa uma conceituação ampla e focada na gênese da expressão, e, sim, entender, ainda que de forma restrita, com que intuito o direito busca sustentação para definir a legislação ambiental.

Não cabe ao direito "a primazia do estudo do meio ambiente, não obstante ser a sua responsabilidade pela elevação do meio ambiente à categoria dos bens jurídicos tutelados pelo ordenamento" (MILARÉ,2004, p. 79). Contudo, estudá-lo de forma multidisciplinar é visto por muitos autores como relevante, por demonstrar a inserção do direito no meio social, possibilitando uma visão holística ${ }^{2}$.

Ter uma visão holística é remeter um olhar para a sociedade e seu hábitat natural e às transformações decorrentes das inserções industriais. Por isso, o conceito de meio atribuído por Milaré (2004, p. 80) "é importantíssimo, pois, além de dar contornos mais precisos à expressão - alvo de controvérsias em campo doutrinário -, também caracteriza o objeto do Direito Ambiental” .

O direito brasileiro concebeu o conceito de meio ambiente pela Lei 6.938/81, que instituiu a Política Nacional do Meio Ambiente, como sendo "o conjunto de condições, leis, influências e interações de ordem física, química e

\footnotetext{
${ }^{2}$ Teoria segundo a qual o homem é um todo indivisível e que não pode ser explicado pelos seus distintos componentes (físico, psicológico ou psíquico) considerados separadamente. (HOLANDA, 2003.)
} 
biológica, que permite, abriga e rege a vida em todas as suas formas." ${ }^{3}$ Contudo, um olhar minucioso percebe que a lei citada se despreocupa com o rigor e a essência científica do conceito de meio ambiente. Isso não é diferente na Constituição de $1988^{4}$, que também não define o conceito, embora estabeleça de forma genérica que o meio ambiente ecologicamente equilibrado é direito de todos.

Milaré (2004, p. 81) afirma que

\begin{abstract}
tanto a Lei 6.938/81 quanto a Lei Maior omitem-se sobre a consideração essencial de que o ser humano, considerado como indivíduo ou como coletividade, é parte integrante do mundo natural e, por conseguinte, do meio ambiente. Essa omissão pode levar facilmente à idéia de que o ambiente é algo extrínseco e exterior à sociedade humana, confundindo-o, então, com seus componentes físicos bióticos e abióticos, ou com recursos naturais e ecossistemas. É de observar que este equívoco passou para as Constituições Estaduais e, posteriormente, para as Leis Orgânicas de grande parte dos Municípios.
\end{abstract}

Em qualquer país a legislação não entra nos méritos específicos de cada ciência, até porque demandaria um debate interminável, não expressando uma objetividade capaz de atender aos objetivos específicos para que é feita. "A lei é instrumento para atender a uma precisão da sociedade, e neste intuito ela é pensada e redigida. (....) este é o caso do meio ambiente" (MILARÉ,2004, p. 81). Percebe-se que a objetividade e a precisão da lei não poderão deixar de contemplar as diversas concepções que permeiam a sociedade, porém, por outro lado, é necessária a adoção de um padrão mediano, que conceituará a vivência das pessoas, neste caso, o direito ambiental.

Mas então, não seria necessária somente a lei para caracterizar o meio ambiente? E por que se passa a defender a existência do direito do ambiente?

O direito, como não pode ficar alheio ao desenvolvimento da consciência política, passou a debater tais questões, não meramente pelos

\footnotetext{
${ }^{3}$ Art. $3^{\circ}$, I da CF/88

${ }^{4}$ Art. 225 , caput da CF/88.
} 
posicionamentos utópicos, mas pela sua objetividade e sabedoria. Segundo Carla Amado Gomes (2000, p.51):

\begin{abstract}
Foi o Direito Internacional (Público) que primeiro traduziu em normas as angústias nascentes ${ }^{5}$. Verdes passaram a ser também os direitos do Homem $^{6}$ : o Pacto Internacional dos Direitos Econômicos, Sociais e Culturais aprovados, em 1966, no seio da Organização das Nações Unidas, consagrou, no artigo 12/1, um dever de promoção da qualidade do meio ambiente por parte dos Estados e, em 1972, surge a Declaração de Estocolmo, fruto da primeira Conferência Mundial sobre a questão ambiental, convocada pela Assembléia Geral da Organização das Nações Unidas. Ao ambiente foi então reconhecido um valor transgeracional, que implica, para os Estados, um dever de uso racional dos recursos naturais, com vista à sua preservação para uso das gerações futuras (intergenerational equity). Num segundo momento, foi a vez do cidadão comum e do Estado se conscientizarem da necessidade de preservação dos bens ambientais, a bem de cada um e de todos, mesmo para além das impotentes fronteiras - pois este é um domínio em que a globalização não perdoa ${ }^{7}$. O Direito interno, público e privado, não podiam, naturalmente, ficar indiferente a esta cruzada.
\end{abstract}

A Declaração de Estocolmo, mencionada pela autora, enfatiza o Princípio 21, no qual orienta que os Estados tenham o direito soberano de explorar seus próprios recursos. Os Estados possuem a incumbência e a responsabilidade, de acordo com a sua política ambiental, de assegurar as atividades levadas a efeito dentro de sua jurisdição ou sob seu controle, mas também devem ter o cuidado de não prejudicar o meio ambiente de outros Estados ou de zonas situadas fora dos limites de sua jurisdição. Essa delimitação teve efeito significativo especialmente nos chamados "países desenvolvidos", porque neles grande parte dos problemas sociais, de certa forma, já havia sido resolvida. Quanto aos países subdesenvolvidos, a tarefa mais árdua era conter problemas básicos como a fome, a miséria, a carência de escolas, de moradias,

\footnotetext{
${ }^{5}$ No nível das organizações internacionais, conforme a criação, em 1948, da União Internacional para a Protecção da Natureza, que em 1954 passou a designar-se União Internacional para a Conservação da Natureza e dos Recursos Naturais, sob a égide da Unesco. Esta organização não governamental foi a responsável pela elaboração da primeira lista de espécies a proteger (Red Data Book) e da estratégia mundial da conservação - cfr. DOMINIQUE DRON, Ambiente e escolhas políticas, Lisboa, 1998, p. 25 segs.

Sobre este ponto, em nível europeu, v. também A. KISS, La protection de l'environnement en Europe. $A E, \mathrm{~V} . \mathrm{XXX}, 1982$, p. 75 segs.

${ }^{6}$ Cfr. VASCO PEREIRA DA SILVA, Verdes são também os direitos do homem..., cit..

7 Como sugestivamente escreve R. RABBI-BALDI CABANILLAS, "la defensa del ecosistema constituye un bien común internacional" Notas para una fundamentación del derecho ambiental. OD, 1996, I/II, 1996.p. 45 segs, 62.
} 
de saneamento básico, de atraso tecnológico e outros, ficando a questão ambiental em segundo plano. O Programa de Meio Ambiente das Nações Unidas, conhecido hoje é resultado da Conferência de Estocolmo. Mesmo manifestando seus princípios com clareza, a Declaração de Estocolmo não conseguiu impedir várias catástrofes na década de 1980 (Chernobyl, 1986; Bhopal, Índia, em 1984, etc.), porém a mundialização favoreceu, em muito, o surgimento de movimentos ambientalistas e dos partidos verdes.

Em 1992, no Brasil, o Rio de Janeiro foi sede da Conferência das Nações Unidas sobre o Meio Ambiente e Desenvolvimento (CNUMAD-92), cujo principal objetivo era reexaminar as estratégias de desenvolvimento. O Princípio 1 estabelece que "os seres humanos constituem o centro das preocupações relacionadas com o desenvolvimento sustentável. Têm o direito a uma vida saudável e produtiva em harmonia com o meio ambiente".

Seguindo o exposto, o princípio da participação (princípio 10), salienta a participação da mulher e de todos os cidadãos interessados na questão ambiental (princípio 20); aborda a participação dos jovens das comunidades indígenas (princípio 21), e outras comunidades locais (princípio 22).

Leila da Costa Ferreira (p.25) argumenta que os resultados da Conferência Rio-92 "ressaltaram a fragilidade de uma cidadania e de uma sociedade civil que está entendendo a duras penas as contradições existentes entre o oficial e o 'oficialesco'. Entre as cidadanias conquistadas e os direitos outorgados".

Assim, observa-se que o direito do ambiente começa a surgir não meramente como uma inovação conceitual do direito ambiental, mas, precisamente, como uma interface da cidadania e dos direitos sociais. Para Milaré (2004, p.42),

reforçaram-se os canais de diálogo ante a convicção de que os cidadãos, com amplos conhecimentos de sua realidade e com acesso à informação, têm melhores condições de atuar sobre a sociedade, de articular mais eficazmente desejos e idéias e de tomar parte ativa nas decisões que lhe interessam diretamente. 
A Constituição Federal de 1988 representa uma abertura de canais para a participação efetiva na vida social tanto do cidadão como da coletividade. Referentemente à questão ambiental, a carta política proporcionou a participação e a atuação da população na preservação e na defesa ambiental, atribuindo à coletividade o dever de defender o meio ambiente (ARTIGO 225, "caput", cf/88) e estabeleceu como direito fundamental a todos os cidadãos brasileiros a proteção ambiental, determinada no artigo $5^{\circ}$, inciso LXXIII, CF/88 (ação popular).

Maria Alice Antonello Londero (1999) afirma que, na CF/ 88, o meio ambiente é um bem de uso comum do povo, assegurando a todos o direito ao meio ambiente equilibrado e impondo ao poder público e à coletividade o dever de defendê-lo e preservá-lo à geração presente e às futuras, e ampliaram as ações judiciais na tutela ambiental. Dessa forma, surgiram novos paradigmas e/ou uma nova visão de proteção ao meio ambiente e ao patrimônio cultural.

\subsection{O MEIO AMBIENTE: UMA VISÃO BRASILEIRA}

Os fatos históricos mostram que a busca desenfreada pelas "necessidades ilimitadas" acentuou-se com o início da ditadura militar, especialmente porque a idéia defendida era crescer e se desenvolver a qualquer custo. Inegavelmente, essa busca incessante pelo desenvolvimento proporcionou ao Brasil avanços em diversas áreas, contudo também aumentou os problemas sociais existentes, talvez até em maior proporção, principalmente, a partir da década de 1950, quando os governos da época procuraram traçar o famoso Plano de Metas, que visava à industrialização rápida e financiada pelo Estado e pelo capital internacional.

Várias empresas, conhecidas na atualidade, surgiram naquele momento e ingressaram na vida econômico-empresarial do Estado, como o Banco Nacional de Desenvolvimento Econômico, (BNDE, hoje BNDES, referindose o "S" a "e Social"), Petrobras, Petróleo Brasileiro S.A. (monopólio estatal), 
Centrais Elétricas de Furnas, usinas siderúrgicas de Minas Gerais (Usiminas), Companhia Siderúrgica Paulista (Coses), Centrais Elétricas S. A. (Eletrobrás), Companhia Brasileira de Alimentos (Cobal), Companhia Brasileira de Armazéns, (Cibrazem), entre muitas outras.

No relato Maria Cristina V. B.Tarrega (2002, p.4):

Entre 1961 e 1967, o país atravessa período recessivo. Após o Governo de Goulart, seguido do golpe militar, enfatiza-se na política econômica a iniciativa privada com atração do investimento estrangeiro. A presença marcante do Estado na iniciativa privada continua com a criação de muitas empresas estatais para atuarem na produção de bens e serviços. Pode-se lembrar o surgimento do BNH, Banco Nacional de Habitação, da Embratel, Empresa Brasileira de Telecomunicações SA, entre outras. A Reforma administrativa governamental, realizada em 1967, estabeleceu procedimentos diferenciados para a administração direta e indireta e criou normas para o funcionamento das autarquias, empresas públicas e de economia mista. As empresas passam a ter por fim o lucro e aumento de participação na economia. Segue-se a esse período o chamado "milagre brasileiro" que perdura até meados da década de setenta e que tem origem acima de tudo, na anterior ampliação de investimentos do Estado. Continua a ampliar-se à intervenção econômica do Estado pela criação de empresas estatais. Há uma expansão significativa no número de empresas federais, estaduais e de subsidiárias dessas.

Percebe-se, portanto, claramente, que o Estado brasileiro concentrou várias empresas em suas mãos, assumindo uma característica econômica bem definida e focada no interesse dos militares em parceria com o capital internacional. Marca forte nesse período é o destaque da Petrobras, porque as energias estavam então fortemente concentradas no petróleo. Objetivamente, o desenvolvimento apregoado pelos interesses privados e econômicos passou a deixar marcas profundas no meio ambiente, do que é exemplo a fama que adquiriu Cubatão como a cidade mais poluída do país. O chamado "milagre brasileiro" da década de 1970 estava preocupado tão somente em atender os anseios do desenvolvimento econômico a qualquer custo.

Nessa década, mesmo com os métodos repressivos em voga, surgiram entidades preocupadas com a preservação do meio ambiente e as consciências 
ecológicas manifestaram-se por intermédio dos movimentos ecologistas internacionais, com um discurso revolucionário e radical ${ }^{8}$, na seqüência de grandes desastres ecológicos. Esses movimentos difundiram uma "nova utopia", como solução de todos os problemas da sociedade, levando ao debate extremo uma questão que, até então, nem entrava no domínio da política, mas começava a ser debatida pelos juristas do país.

Uma revisão histórica revela que o direito do ambiente há muito tempo vem sendo estudado, especialmente pelo interesse de frear a exagerada interferência dos seres humanos e das suas instituições na natureza e no meio ambiente. Todavia, um conceito de direito do ambiente construído levando em consideração a realidade brasileira foi trabalhado por Édis Milaré (2004): “O Direito do Ambiente é um complexo de princípios e normas coercitivas reguladoras das atividades humanas que, direta ou indiretamente, passam afetar a sanidade do ambiente em sua dimensão global, visando a sua sustentabilidade para a presente e futuras gerações" (p.134).

O conceito proposto pelo autor não é unânime, visto que varia de país para país e, mesmo, de autor para autor, o que pode ser considerado normal num ramo de direito jovem e em formação. No conceito de Milaré observa-se um enfoque interdisciplinar e multidisciplinar, podendo ser definido como o conjunto de princípios e regras que disciplinam todas as atividades direta ou indiretamente relacionadas ao uso racional dos recursos naturais, bem como a promoção e proteção dos bens culturais, tendo por objetivo a defesa e a preservação do patrimônio ambiental e cultural e, por finalidade, ligado à vida em geral, tanto a presente como a futura.

O direito do ambiente é, por sua vez, distinto do direito ecológico, pois compreende a proteção do patrimônio natural ou ambiental e cultural, ao passo que este último visa apenas à proteção dos recursos naturais.

8 Revolucionário, especialmente, porque os regimes militares consideravam tais atitudes decorrentes das ondas comunistas. 
Com o seu conceito, Milaré (2004, p.47) rompeu com o pragmatismo da lei pela lei e buscou nos conceitos básicos da ciência e na visão crítica dos fatos a sua sustentação, como se pode verificar quando afirma:

O desequilíbrio ecológico acentua-se a cada dia que passa......Todo o saber científico, contido na Geociência, nas Biociências e nas Ciências Humanas, fala da fragilidade do mundo natural e da agressividade dominante. $O$ Direito também conhece essa responsabilidade e essa complexa realidade, em que se joga com o porvir incerto da oikos e de todos os seus moradores, ou seja, da Terra e de tudo quanto nela se encontra.

Édis Milaré trata faz uma abordagem baseada em sustentações epistemológicas $^{9}$ e na filosofia das ciências, tanto do ponto de vista legal quanto científico. Assim, pode-se dizer que não é aleatório e prófugo. O autor ${ }^{10}$ (2004, p.47) ressalta que a degradação do meio natural em virtude da ação humana, potenciada pelo crescimento industrial verificado no último século, é por demais conhecida, revelando em seus escritos a perplexidade em relação à situação que se vive.

\begin{abstract}
Este é o palco em que se desenrola o drama da vida sobre o Planeta. A Questão Ambiental está desenhada nos cenários da humanidade e manifesta-se através das ações visíveis, que podem ser facilmente constatadas; porém, não é possível ignorar o que se passa nos bastidores, nas ações ocultas e no jogo de interesses que não vêm à cena. A vigilância ambiental, inclusive a consciência jurídico-ecológica, deve estar atenta ao que é patente e ao que esta latente.
\end{abstract}

Confirmam-se tais fatos diariamente na imprensa do país, em reportagens sobre agressões ao meio ambiente, que vão da simples poluição caseira à exploração econômica da madeira para fins e interesses meramente econômicos. Nesse sentido, a vigilância ambiental proposta por Milaré para tais

\footnotetext{
${ }^{9}$ Conjunto de conhecimentos que têm por objeto o conhecimento científico, visando a explicar os seus condicionamentos (sejam técnicos, históricos, ou sociais, sejam lógicos, matemáticos, ou lingüísticos), sistematizar as suas relações, esclarecer os seus vínculos e avaliar os seus resultados e aplicações. (Holanda , 2003).

${ }^{10}$ Milaré utiliza a afirmação de H. G. Wells de que "a história humana é cada vez mais uma corrida entre a educação e o desastre" ( p. 46)
} 
acontecimentos provocará conflitos e disputas sociais e, precisamente, de cunho jurídico.

Tudo decorre de um fenômeno comum, segundo o qual os homens, para a satisfação de suas novas e múltiplas necessidades, que são ilimitadas, disputam os bens da natureza, por definição limitada. É esse fenômeno, tão simples quanto importante, que está na raiz de grande parte dos conflitos que se estabelecem no seio da comunidade (p.47).

O direito do ambiente, segundo Milaré, sustenta-se em princípios explicados pelo autor:

O primeiro ${ }^{11}$ é o princípio do ambiente ecologicamente equilibrado como direito fundamental da pessoa humana. Vincular o ambiente à condição básica da vida é o argumento forte do autor nesta circunstância, neste caso não meramente pelo fato da existência, mas, sim, vinculado a um ambiente sadio. "É, sem dúvida, o princípio transcendental de todo o ordenamento jurídico ambiental, ostentando o status de verdadeira cláusula pétrea" (p.138).

O segundo princípio é o da natureza pública da proteção ambiental. A natureza pública deve assegurar o desenvolvimento coletivo; portanto, assegurar o direito ao meio ambiente sadio é de responsabilidade do Estado. Para Cristiane Derani (apud MILARÉ, 2004, p.138), "seguindo a lógica desta constatação, a proteção ao meio ambiente não pode mais ser considerada um luxo ou utopia, pois o reconhecimento desse interesse geral permitirá um novo controle de legalidade e estabelecerá instrumentos aptos a fazer respeitar o novo objetivo do Estado".

Em Milaré e Deran (2004, p. 139) constata-se claramente a ênfase de que o poder público deve a assegurar não só a proteção do meio ambiente, mas garanti-lo como um patrimônio público.

\footnotetext{
11 Milaré não faz a distinção entre primeiro, segundo, terceiro, etc., mas julga-se conveniente utilizar esta modalidade para seguir uma lógica de entendimento ao leitor leigo neste assunto.
} 
O princípio ora em exame estreita vinculação com o princípio geral de Direito Público da primazia do interesse público e também com o princípio do Direito Administrativo da indisponibilidade do interesse público. É que o interesse na proteção do ambiente, por ser de natureza publica, deve prevalecer sobre os direitos individuais privados, de sorte que, sempre que houver dúvida sobre a norma a ser aplicada a um caso concreto, deve prevalecer aquela que privilegie os interesses da sociedade - a dizer, in dúbio, pro ambiente. De igual sentir, a natureza publica que qualifica o interesse na tutela do ambiente, bem de uso comum do povo, torna - o também indisponível.

O autor confirma o estabelecido na Lei 6.938/81, em seu artigo 225, caput de que o meio ambiente como patrimônio público é "bem de uso comum do povo e essencial à sadia qualidade de vida". Logo, o interesse privado ou os movimentos públicos não devem transgredir em matéria ambiental.

Como terceiro princípio sustentador do direito do ambiente tem-se o controle do poluidor pelo poder público, que "resulta das intervenções do Poder Público, necessárias à manutenção, preservação e restauração dos recursos ambientais com vistas à sua utilização nacional e disponibilidade permanente" (MILARÉ, 2004, p. 139). Para o autor este princípio se materializa pela capacidade do exercício da ação e do poder de polícia administrativa que o Estado detém. Cabe à administração pública conter, em momento algum de forma autoritária, os direitos individuais, com o objetivo de garantir o bem-estar do coletivo. Contudo, o poder de polícia, aqui entendido pelo autor, e corrobora-se esta visão, deve assumir um caráter pedagógico, não meramente repreensivo. $O$ poder público deve, primeiramente, assegurar o espaço para composição "com os agentes poluidores, de molde a estabelecer ajustamentos de conduta que levam à cessação das atividades nocivas" (p.139).

O quarto princípio é o da consideração da variável ambiental no processo decisório de políticas de desenvolvimentos. "Esse princípio diz da elementar obrigação de se levar em conta a variável ambiental em qualquer ação ou decisão - pública ou privada - que possa causar algum impacto negativo sobre o meio" (MILARÉ, 2004, p.140). Na década de 1960, este tema já era objeto de reflexão nos Estados Unidos e, objetivamente, fez surgir o Estudo de Impacto ambiental (EIA) que visa abrandar atos lesivos ao meio ambiente e 
prevenir agressões ao meio, o que significa antecipadamente reduzir a agressividade do homem. $\mathrm{Na}$ realidade brasileira, a matéria tem peso constitucional e, sobretudo, foi fundamentada fortemente no princípio 17 da Declaração do Rio de Janeiro. O princípio 17 afirma: "Avaliação do impacto ambiental, como instrumento nacional, deve ser empreendida para atividades planejadas que possam vir a ter impacto negativo considerável sobre o meio ambiente, e que dependam de uma decisão de autoridade nacional competente". Inicialmente, a implantação dessa avaliação, na realidade brasileira gerou reações de indignação, especialmente dos empresários mais despreocupados com o meio ambiente e interessados exclusivamente no lucro.

O quinto princípio, da participação ${ }^{12}$ comunitária, "expressa a idéia de que para a resolução dos problemas do ambiente deve ser dada especial ênfase à cooperação entre o Estado e a sociedade, através da participação dos diferentes grupos sociais na formação e na execução da política ambiental" (MILARÉ, 2004, p.140-1). Deve, pois, haver o envolvimento das comunidades, especialmente das atingidas por empreendimento de grande porte ou de ações políticas para implementação ações mais equilibradas para com o meio ambiente. $\mathrm{O}$ art. 225, caput, da Constituição Federal enfatiza que cabe ao poder público e à coletividade o dever de defender e de preservar o meio ambiente para as gerações presentes e às futuras (MILARÉ, 2004).

Milaré (2004, p.141) afirma, categoricamente, que

o direito à participação pressupõe o direito de informação e está a ele intimamente ligado. É que os cidadãos com acesso à informação têm melhores condições de atuar sobre a sociedade, de articular mais eficazmente desejos e idéias e de tomar parte ativa nas decisões que Ihes interessam diretamente.

A informação a que o autor está se referindo está condicionada não somente aos meios de comunicação, isto é, utilizar o rádio, a televisão e os

12 Segundo o dicionário Aurélio, participação é "fazer saber; informar, anunciar, comunicar". 
jornais para divulgar os elementos que compõem a questão ambiental, mas implica considerar as formas de capacidade organizativa da sociedade, a chamada "sociedade civil organizada".

Expressivamente, pode-se ressaltar que no Brasil o número dessas entidades tem aumentado significativamente nos últimos anos com a abertura política. A informação é elemento crucial para o desenvolvimento do processo de sensibilização para a preservação e,muito mais, para poder proporcionar condições aos órgãos fiscalizadores, muito incipientes e com grandes dificuldades administrativas ${ }^{13}$. A informação deve estar estreitamente vinculada a métodos claros e transparentes, para que se possa pensar sem sofrer qualquer retaliação que possa inibir a atuação social e democrática. Milaré (2004, p.141) salienta que

de fato, é fundamental o envolvimento do cidadão no equacionamento e implementação da política ambiental, dado que o sucesso desta supõem que todas as categorias da população e todas as forças sociais, conscientes de suas responsabilidades, contribuam para a proteção e a melhoria do ambiente, que afinal, é bem e direito de todos. Exemplo concreto de aplicação deste princípio é a garantia estabelecida por lei de realização de audiências públicas no curso de processos de licenciamento ambiental que demandem a realização de estudos prévios de impacto ambiental ${ }^{14}$.

Percebe-se pela afirmação do autor, que a mera participação está potencialmente descartada, porque participar por participar não é produtivo; é necessário atrelar a participação do indivíduo com as instituições significativamente com representatividade social e conscientes de suas responsabilidades para com os cidadãos e o meio ambiente.

O sexto princípio, do poluidor-pagador, "assenta-se na vocação redistributiva do Direito do Ambiente e se inspira na teoria econômica de que os custos sociais externos que acompanham o processo produtivo (v.g., o custo resultante dos danos ambientais) precisam ser internalizados, vale dizer que os

\footnotetext{
${ }^{13}$ Neste caso estamos nos referindo à grande amplitude para ser fiscalizado e aos limites físicos que o Ibama e outros órgãos encontram para realizar com eficiência e eficácia seu trabalho.

${ }^{14}$ Grifo meu
} 
agentes econômicos devem levá-los em conta ao elaborar os custos de produção e, conseqüentemente, assumi-los" (MILARÉ, 2004, p. 142)

O princípio do poluidor-pagador tem chamado muito a atenção da sociedade, e particularmente dos meios de comunicação de massa, a qual tem cumprido o papel de internalizar de forma gritante os danos ao meio ambiente, com interesses únicos e exclusivos de um proprietário, seja de uma grande, média e/ou pequena fábrica ou produtor rural. Cabe salientar que as grandes corporações, nos últimos anos, têm sido comedidas em suas ações poluidoras, especialmente porque o mercado comprador tem exigido certificações que comprovem o mínimo de dano ambiental.

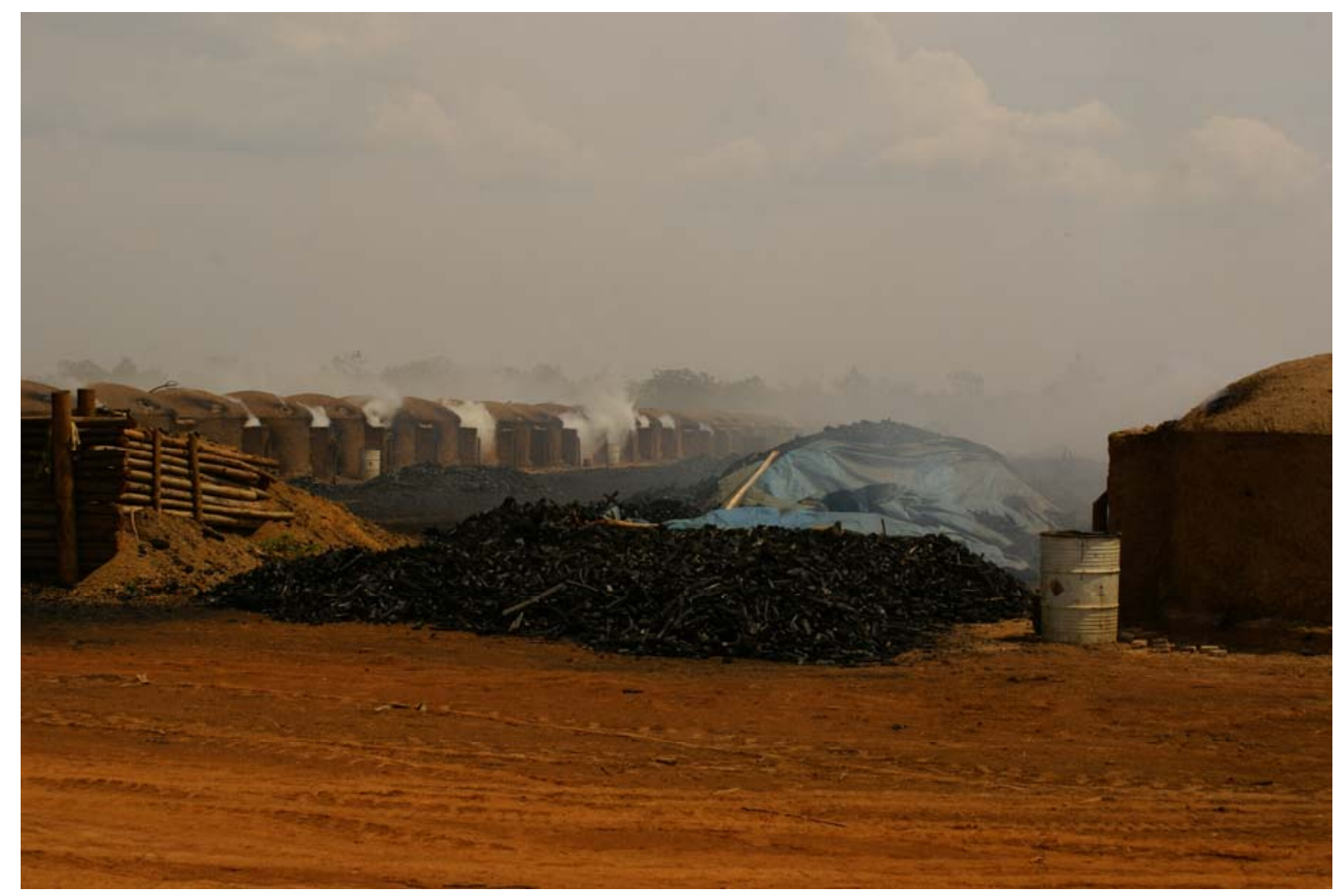

Figura 1- elementos poluidores para fins financeiros 


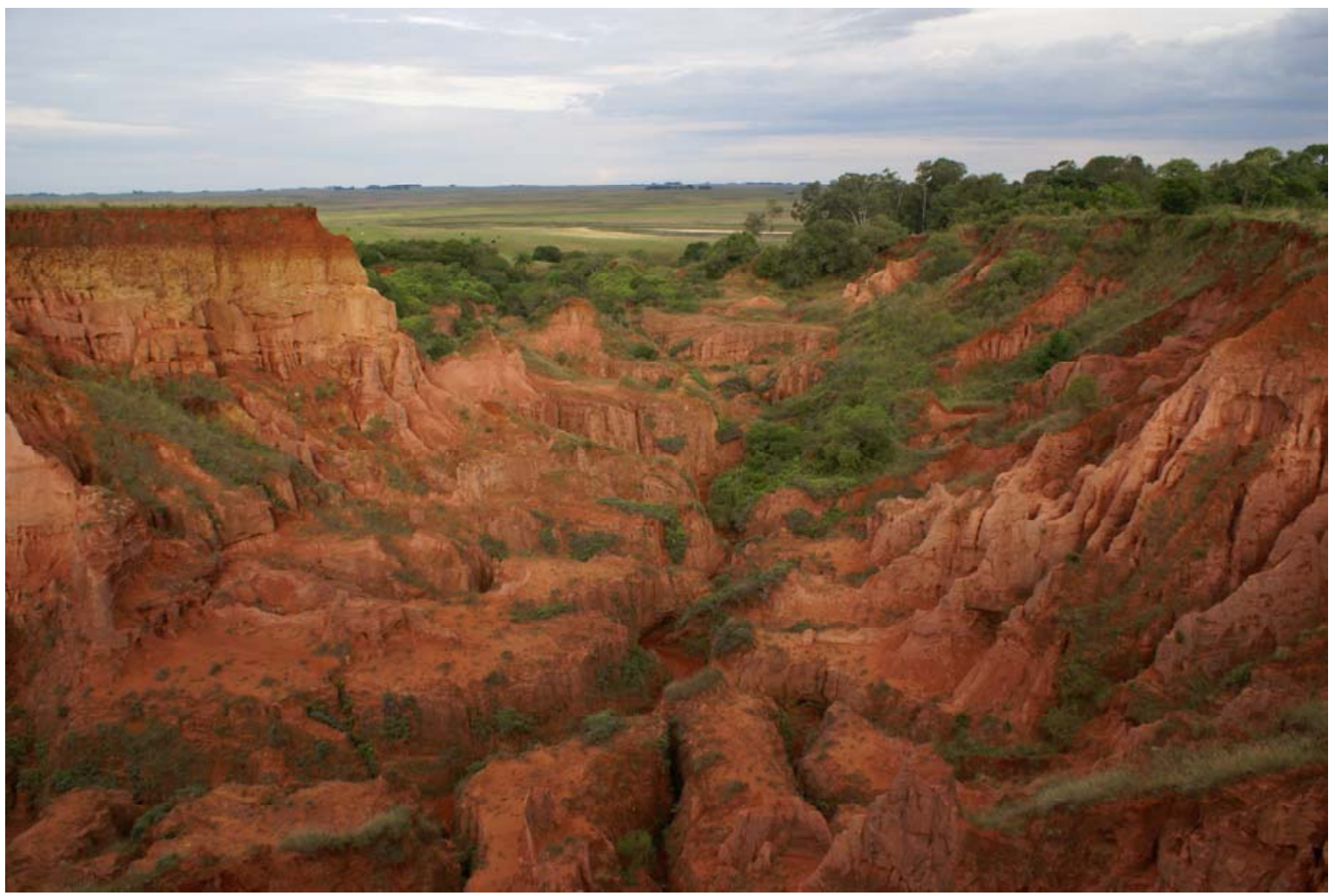

Figura 2 - desequilíbrio ambiental

Milaré ( 2004, p. 142) afirma:

Durante o processo produtivo, além do produto a ser comercializado, são produzidas, "externalidades negativas"'. São chamadas externalidades porque, embora resultantes da produção, são recebidas pela coletividade, ao contrário do lucro, que é percebido pelo produtor privado. Daí a expressão "privatização de lucros e socialização de perdas",quando identificadas as externalidades negativas. Com a aplicação do princípio do poluidor-pagador, procura-se corrigir este custo adicionado à sociedade, impondo-se sua internalização. Por isto, este princípio é também conhecido como princípio da responsabilidade.

O interessante, nesse princípio, é que enfatiza a responsabilidade social através do aspecto econômico, Isto é, se poluiu, paga. Contudo, esclarece Milaré, "o princípio não objetiva, por certo, tolerar a poluição mediante um preço, nem se limita apenas a compensar os danos causados, mas sim, precisamente, evitar o dano ao ambiente". O autor ainda salienta que o fato de pagar pelo dano causado não lhe dá o direito de poluir em outro momento, ou precisamente, pagar 
para poluir. A legislação brasileira, seja pela Lei da Política Nacional do Meio Ambiente - 1981, seja pela Constituição Federal de 1988, deixa claro que o poluidor será responsabilizado administrativamente e pelas vias penais cabíveis, isso independentemente de já ter reparado os danos causados ao meio ambiente.

O sétimo princípio, é o da prevenção, que consiste em "balizar em Direito Ambiental, concernindo à prioridade que deve ser dada às medidas, que evitem o nascimento de atentado ao ambiente, de modo a reduzir ou eliminar as causas das ações suscetíveis de alterar sua qualidade" (MILARÉ, 2004, p.144).

No princípio anterior percebe-se toda uma fundamentação para punir os infratores por meio de medidas penais e administrativas, o que é justificável em determinadas circunstâncias. Neste princípio, nota-se que a preocupação está em conduzir o processo de forma a desenvolver uma ação educativa para com o meio ambiente junto à sociedade. Quando este princípio for encarado como uma ação constante, certamente produzirá efeitos de responsabilidade social e fará com que as pessoas compreendam que a degradação não é uma regra.

O estudo de impacto ambiental, previsto no art. $225, \S 1^{\circ}$, IV, da CF, bem como a preocupação do legislador em controlar a produção, a comercialização e o emprego de técnicas, métodos e substâncias que comportem risco para a vida, a qualidade de vida e o meio ambiente, manifestado no mesmo artigo, inciso V, são exemplos típicos desse direcionamento preventivo.

Prevenir é um ato significativo de responsabilidade social e que pode conduzir a um processo de ampliação da participação comunitária, especialmente porque, quando o legislador e a lei divulgam, demonstram claramente que o meio ambiente não é privilégio de determinados setores ou classes que usufruem constantemente dos recursos disponíveis. Por isso, a precaução deve ser direcionada para as camadas mais pobres da população, mesmo que estas não se encontrem com seus direitos básicos plenamente atendidos. Um exemplo disso é orientar as crianças e os pais de uma vila carente a disporem o lixo que produzem num lugar apropriado para posteriormente ser destinado ao lugar certo. 


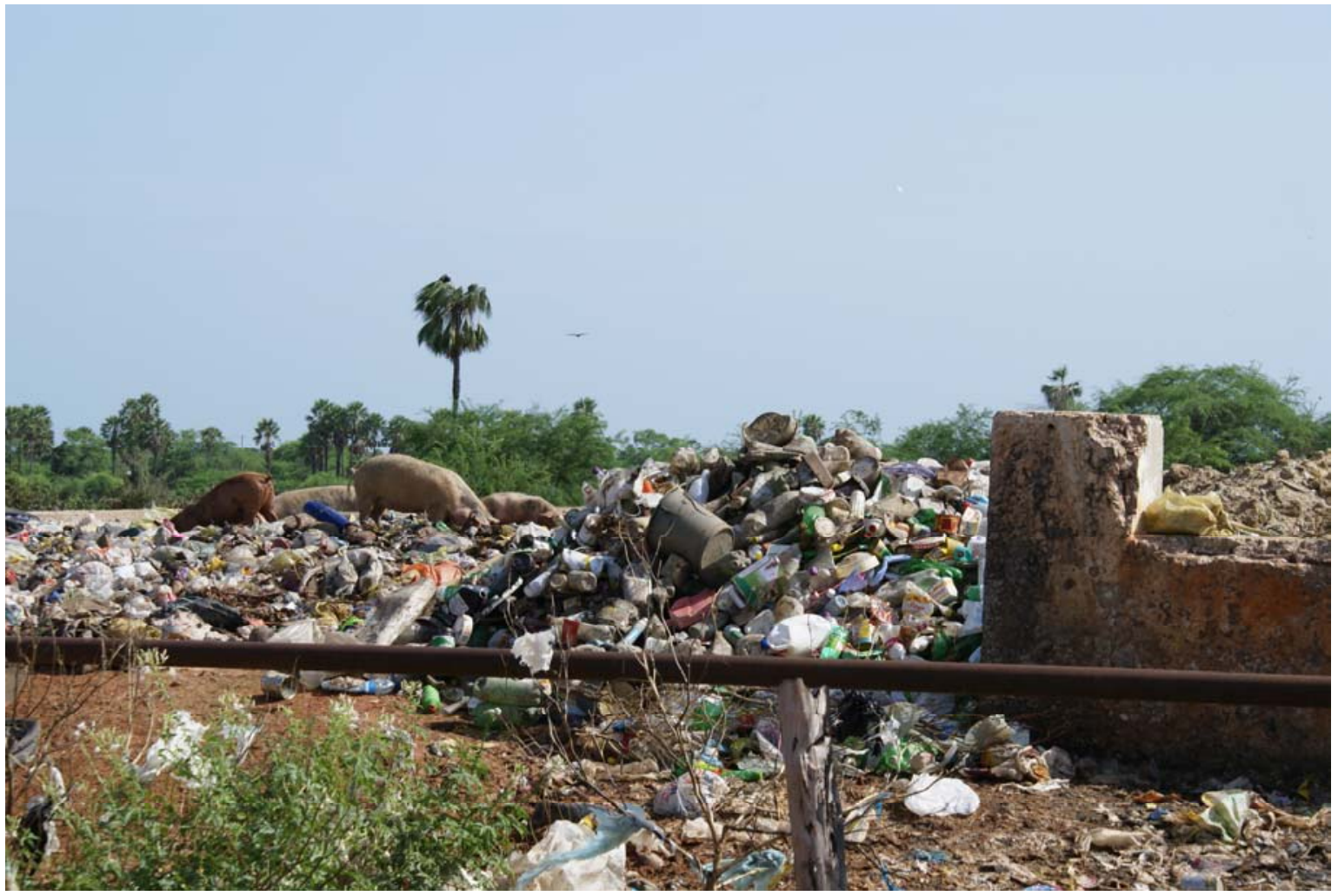

Figura 3 - depósito de lixo em céu aberto em pequenas comunidades

O oitavo princípio, da função socioambiental da propriedade, provê: "Concebida como direito fundamental, a propriedade não é, contudo, aquele direito que possa erigir-se na suprema condição de ilimitado e inatingível". Milaré utiliza uma afirmação de Kildare Gonçalves Carvalho de que "a propriedade, sem deixar de ser privada, se socializou, com isso significando que deve oferecer à coletividade uma maior utilidade, dentro da concepção de que o social orienta o individual" (1997, p.217).

Quando as ações da propriedade se destinam à coletividade, passa-se a compreender que as implicações e as responsabilidades dos indivíduos (proprietários) devem ser asseguradas. Contudo, eles jamais devem denegrir os interesses da coletividade. Nesse sentido, Milaré (2004, p.147) afirma que 
o uso da propriedade pode e deve ser judicialmente controlado, impondoIhe as restrições que forem necessárias para a salvaguarda dos bens maiores da coletividade, de modo a conjurar, por comandos prontos e eficientes do Poder Judiciário, qualquer ameaça ou lesão à qualidade de vida. é com base nesse princípio que se tem sustentado, por exemplo,a possibilidade de imposição ao proprietário rural do dever de recomposição da vegetação em áreas de preservação permanente e reserva legal, mesmo que não tenha sido ele o responsável pelo desmatamento.

A citação expressa que todas as atitudes do dono da propriedade devem ser tomadas no seu interesse, mas sem jamais ferir ou denegrir a condição da coletividade. Logo, percebe-se que a propriedade privada exerce um grande papel social, objetivamente, de responsabilidade social.

No nono princípio, do direito ao desenvolvimento sustentável, "infere-se a necessidade de um duplo ordenamento - e, por conseguinte, de um duplo direito - com profundas raízes no Direito natural e no Direito Positivo: o direito do ser humano em desenvolver-se e realizar suas potencialidades, individual ou socialmente, e o direito de assegurar aos seus posteriores as mesmas condições favoráveis" (MILARÉ, 2004, p. 148).

A Comissão Mundial sobre Meio Ambiente e Desenvolvimento define o desenvolvimento sustentável como "aquele que atende às necessidades do presente sem comprometer a possibilidade de as gerações futuras atenderem a suas próprias necessidades" (1991, p.46).

No momento em que se percebem as condições favoráveis ao desenvolvimento, seja particular, seja coletivo, deve-se entender que as atitudes do momento se realizam com fins momentâneos, mas é necessário deixar para as próximas gerações um legado sustentável e marcado pela ótica da responsabilidade. O capitalismo, com a aceleração econômica, desencadeou uma ação agressiva contra o meio ambiente, tanto que em vários momentos históricos provocou catástrofes ambientais. Estudar sobre o desenvolvimento sustentável demandaria um longo exercício, que não é o caso neste momento. Todavia, é fundamental entender que a busca pelo desenvolvimento não significa meramente acumular em detrimento de qualquer coisa; é necessário agir de forma 
sustentável, isto é, responsável. A respeito, Milaré (2004) salienta que "no princípio do desenvolvimento sustentável, direito e dever estão de tal forma imbricados entre si que, mais do que termos relativos, são termos recíprocos, mutuamente condicionantes. Daí a legitimidade, a força e a oportunidade deste princípio como referência basilar do direito do ambiente" (p.150).

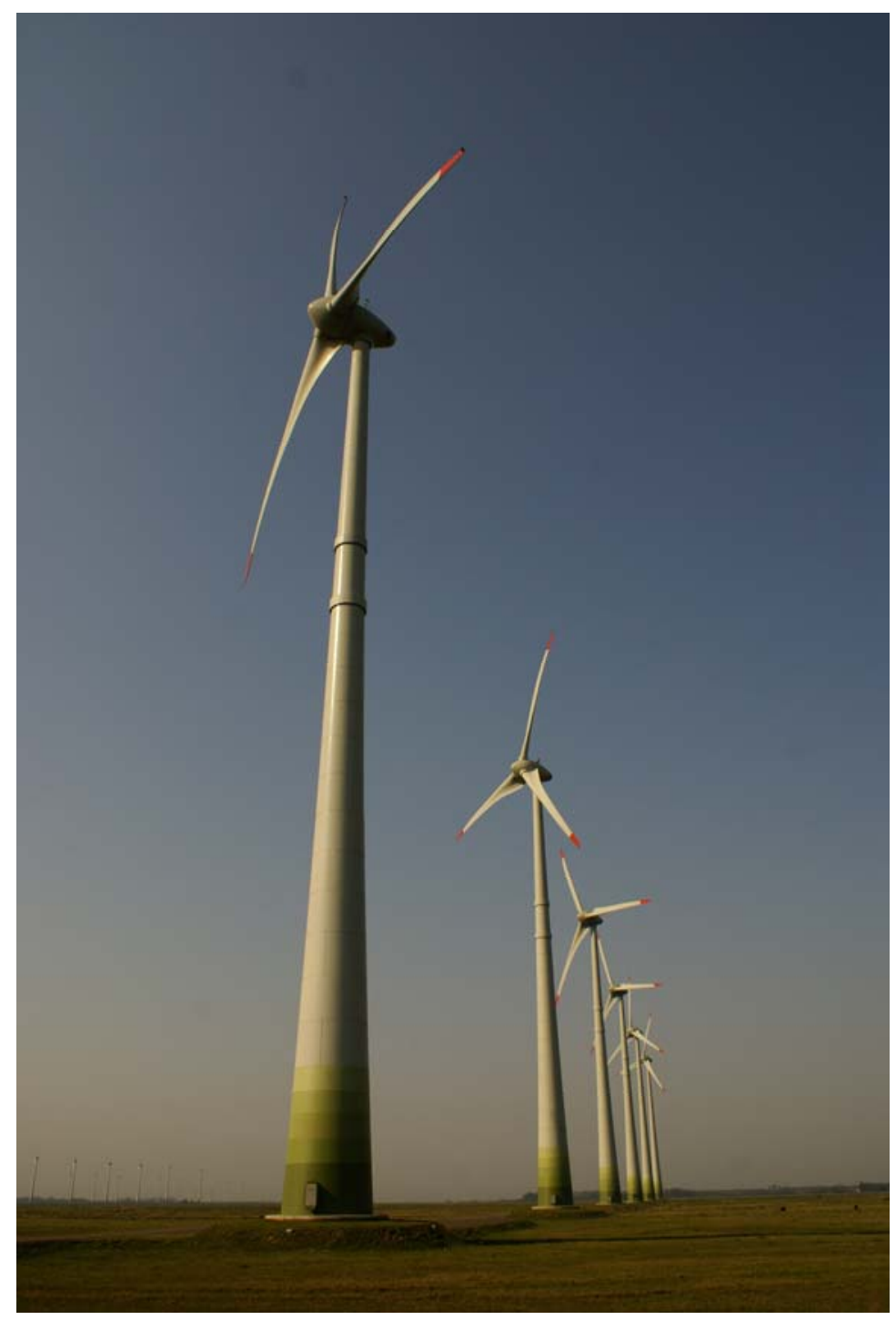

Figura 4 - energia alternativa (aeólica)

No décimo princípio, da cooperação entre os povos, cumpre-se o exposto no art. $4^{\circ}$, IX, no Estatuto Supremo, que ressalta que as relações da República Federativa do Brasil 'cooperação entre os povos para o progresso da 
humanidade. Neste princípio observa-se que a preocupação com a situação dos demais países é no sentido de garantir a segurança da própria nação. A mútua cooperação para com o meio ambiente teve crescimento significativo após a ECO 92 e com a Agenda 21, sem contar outras medidas de cunho geopolítico diferenciado. Com todos os acordos na área ambiental, Milaré (2004, p. 152) ressalta que "um país signatário de acordos bilaterais e multilaterais, por força do Direito Internacional, passa a ser sujeito de obrigações contraídas nos termos estipulados. $\mathrm{Na}$ atual conjuntura planetária, a cooperação internacional sobre ser necessária, poderá ser exigível, e isso pode criar direitos e obrigações ad intra."

Nesse sentido, "os dez princípios anteriormente expostos - decorrem dedutivamente do conhecimento do mundo natural e dos propósitos da sociedade humana" (MILARÉ, 2004, p. 152). Os princípios propostos por Milaré não correm como uma via paralela à legislação vigente no Brasil sobre as questões ambientais, mas elucidam e contribuem para o processo de reflexão sobre o tema, e mais, envolvem a cooperação de outras ciências para balizar a legislação ambiental existente.

Juntamente com o meio ambiente encontra-se a preservação do patrimônio cultural, pois ambos são elementos objeto de eterna luta de proteção e preservação.

\subsection{O PATRIMÔNIO CULTURAL}

Como a ciência, o patrimônio cultural está associado aos conceitos de globalização, não de forma pejorativa e excludente, como em vários aspectos econômicos, mas de maneira valorativa. A proximidade dos conceitos ciência e patrimônio cultural está na sua essência, isto é, de o patrimônio cultural ser dialeticamente inovador e crítico em relação aos novos paradigmas. $O$ "Patrimônio Cultural está historicamente associado à noção do sagrado, ou à noção de herança, de memória do indivíduo, de bens de família" (SANTOS, 2001, 
p. 43). Tal relação permeia a individualidade das pessoas, desde o simples cidadão ao intelectual, doutor do saber, do público ao privado.

A memória deve estar viva, presente na atualidade, no entanto o desejo para avançar deve estar alicerçado na memória. Joachim Hermann apud Funari (2001, p. 2) afirma que

uma consciência histórica é estreitamente relacionada com os monumentos arqueológicos e arquitetônicos e que tais monumentos constituem importantes marcos na transmissão do conhecimento, da compreensão e da consciência histórica. Não há identidade sem memória.

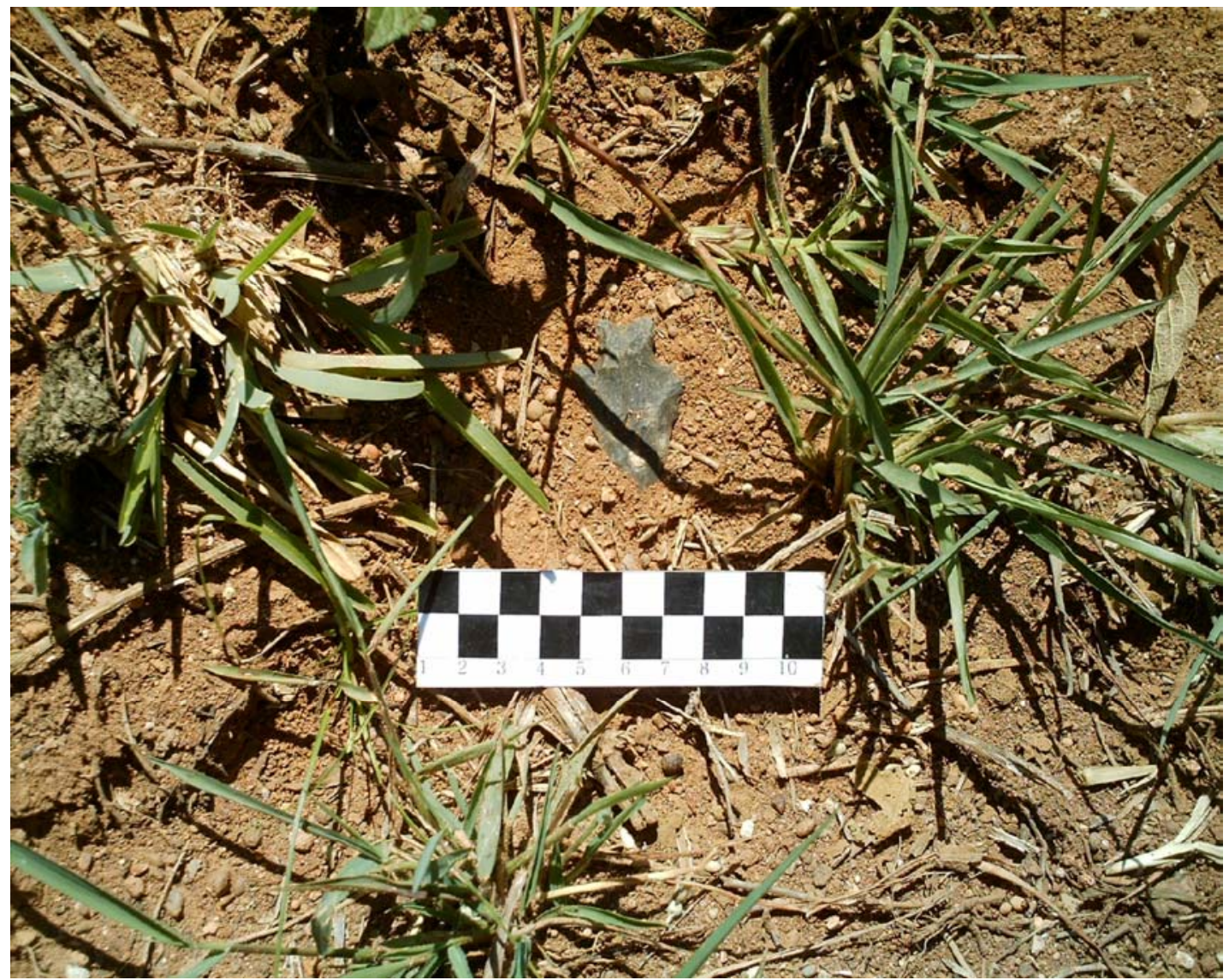

Figura 5 - projétil encontrado em atividades de campo 


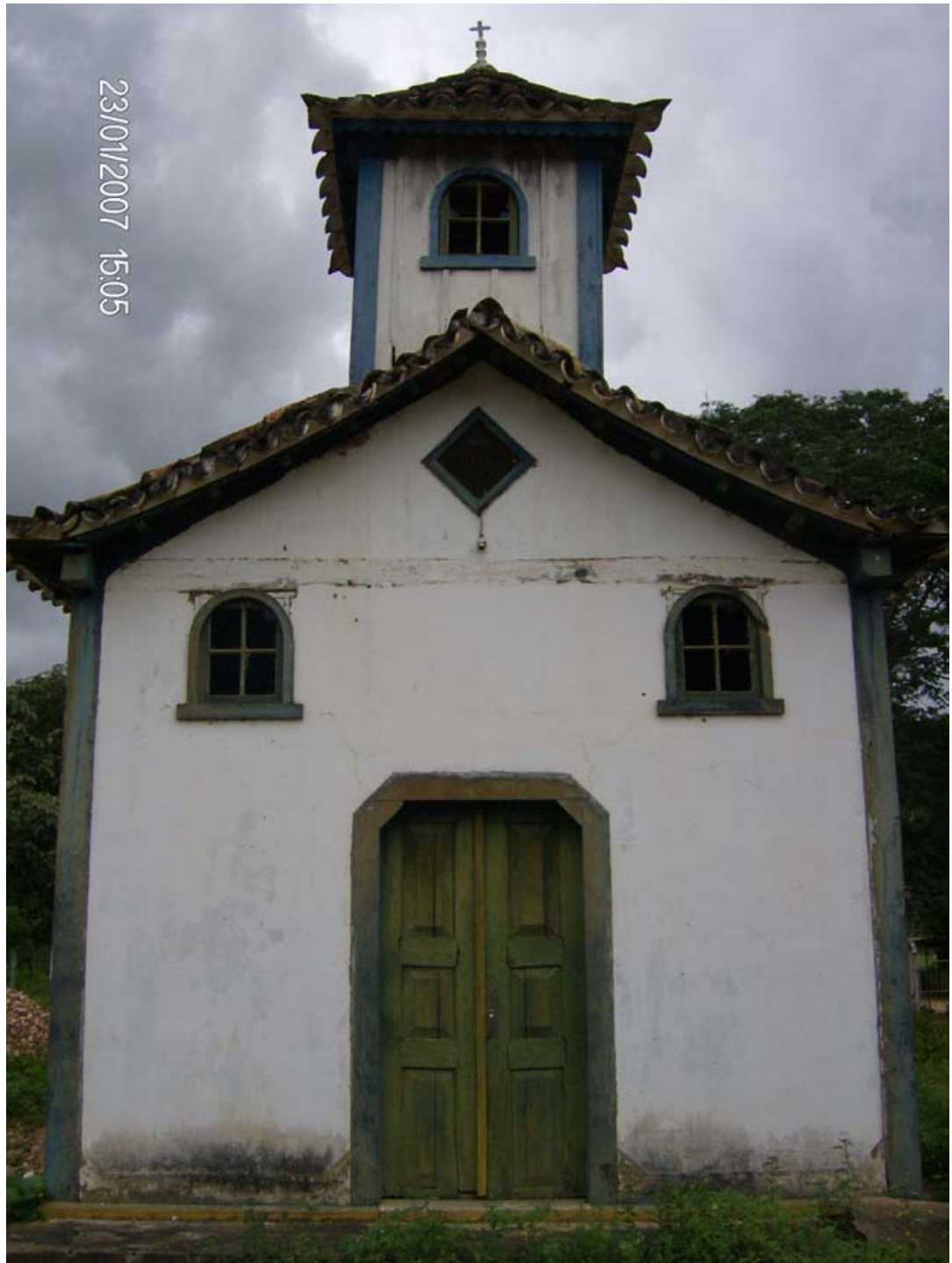

Figura 6 - patrimônio arquitetônico

Nesse sentido, buscar entender o patrimônio cultural isolado das características individuais e coletivas é um equívoco, quando não um desrespeito para com a sociedade. Tanto a ciência quanto o patrimônio cultural têm responsabilidades sociais, mas, principalmente, devem estar voltados à busca de melhorias de vida da população. Havia o tempo em que fazer ciência, para a aristocracia, era obrigação; hoje, a ciência deve se voltar a todas as camadas sociais, pois se assim não acontecer, é claro que estão equivocados os seus princípios. Ao patrimônio cabe a mesma filosofia, isto é, não existem ciência e patrimônio cultural sem legitimidade do povo e das massas. Porém, cada sociedade considera o seu patrimônio com critérios específicos da sua realidade cultural e relaciona-os com os seus testemunhos. 
Salienta Santos (2001, p.43):

Se esse patrimônio, que é de todos, deve ser preservado, é preciso estabelecer seus limites físicos e conceituais, as regras e as leis para que isto aconteça: 'foi a idéia de nação que veio garantir o estatuto ideológico (do patrimônio), e foi o Estado nacional que veio assegurar, através de práticas específicas, a sua preservação (...). A noção de patrimônio se inseriu no projeto mais amplo de construção de uma identidade nacional, e passou a servir ao processo de consolidação dos estados-nação modernos.

Como a ciência possui ética e regra, ao patrimônio cultural deve ser dado esse mesmo tratamento, concedido pelo Estado, instituição que, na sua essência, deveria atender a todos sem qualquer distinção. Nesse sentido, Carlos Alberto Dória (2001, p.85) assinala:

\begin{abstract}
A primeira intervenção do Estado na esfera cultural está centrada precisamente na definição do que a sociedade deva reconhecer como cultura. Na tradição ocidental pós-iluminista, o Estado aparece de modo crescente como um agente do processo cultural: ele produz cultura ou administra sua produção e difusão pelos agentes privados. Na verdade, ele fixa e define para a sociedade, em cada momento histórico, o que se reconhece como cultura. Isso é verdade, especialmente, a partir do romantismo do século XIX, quando as idéias de nação e povo adquirem um claro conteúdo simbólico, capaz de produzir instituições, e a elas devotadas. Paralelamente, por procedimentos de caráter educacional, o Estado propicia a via de acesso a certos domínios culturais que não são gerais. Assim é, por exemplo, com a alta cultura que, para sua fruição plena, exige o cidadão formado de modo específico (exemplos: a música clássica, os estilos pictóricos, arquitetônicos, etc.). Por fim, acaba o Estado destacando do conjunto indeterminado da cultura da sociedade um subconjunto que deve ser tomado como patrimônio de todos e o submete a políticas específicas de produção, difusão, consumo, proteção. Como tende a só reconhecer traços culturais consolidados, ele sempre está em descompasso ou defasagem com a produção cultural do momento e sua ação consiste justamente em administrar este descompasso preparando a passagem do momento inicial para o seguinte.
\end{abstract}

Se o Estado pretender ser o regulador da ciência como o é da cultura e do patrimônio cultural ter-se-á uma ciência alienada e dominadora. Por outro lado, a cultura e o patrimônio cultural necessitam do Estado como instituição mediadora e condutora de determinadas políticas, seja de acesso, seja de fomento. A condução dessas políticas deve ser enfatizada não só pelo controle de órgãos 
governamentais, mas, sobretudo, pelo incentivo da responsabilidade civil e subjetiva. Esse encargo de subjetividade se visualiza nas ações de grupos, etnias e/ou regiões que expressam suas atividades culturais voltadas a conservar e a alimentar sua consciência subjetiva.

Certamente, a presença do Estado na cultura e gestão do patrimônio cultural deve se dar da forma mais democrática possível, isto é, considerando a diversidade, porque, como afirma Zarankin (2002, p.15), "a cultura material é carente de significados por ela mesma, e só adquire uma dimensão ativa dentro de um sistema cultural determinado." Estar em situação determinada não anula a capacidade dialética que deve existir nos objetivos do patrimônio cultural.

A arqueologia é exemplo do patrimônio cultural, seja a arqueologia da pré-história, a arqueologia histórica, a arqueologia de projetos ou contrato e tantas outras específicas, enfim, todas que demonstrem significativamente a sua capacidade dialética de ser, que trabalhem com elementos materiais, imateriais e, sobretudo, mantenham um caráter inter e transdisciplinar $^{15}$ de forma extraordinária. Prova contundente dessa importância é o que Funari (2003, p.08) afirma:

\begin{abstract}
Informação, criação de consciência, ação no mundo, transformação, eis as metas da preservação. Seria, até mesmo, o caso de propor que se deva preservar para transformar a sociedade, pois o conhecimento não é o apanágio de classe ou grupo e qualquer ação preservacionista pode levar à reflexão crítica. Abrir a cabeça, talvez à meta maior da preservação. A começar por uma política que se contraponha à alienação da moda e à descontextualização derivada da mercantilização generalizada dos objetos e dos edifícios em nossa sociedade pósmoderna, que contribua para a autonomia do público. O passado, em forma de patrimônio material, serve ao presente.
\end{abstract}

No momento em que o patrimônio material, como afirma o autor citado, serve ao presente, permite-se considerar que o tempo e o espaço exercem forte influência sobre a arqueologia. Essa influência não deve ser exercida de modo abstrato, isto é, distante dos cidadãos, mas próximo, revelando mudança de valores, de modo que o patrimônio arqueológico não seja apenas a lógica do

15 O exemplo real encontra-se na arqueologia de projetos e/ou arqueologia de contrato, que, significativamente, se aproxima da legislação ambiental. 


\begin{abstract}
"monumento" em praça pública ou reservada aos "PHDeuses ${ }^{16 "}$ nos laboratórios das universidades, nos museus ou institutos governamentais responsáveis pela preservação e conservação. Para José Luiz de Morais ${ }^{17}$ (2001, p. 84),
\end{abstract}

patrimônio arqueológico é o termo genérico que engloba o conjunto de expressões materiais da cultura referente às sociedades indígenas précoloniais e aos diversos segmentos da sociedade nacional (inclusive as situações de contato interétnico), potencialmente incorporáveis à memória local, regional e nacional, compondo parte da herança cultural legada pelas gerações do passado às gerações futuras (p.84).

\title{
Em 2004, com a portaria IPHAN 230/02 em vigor, segundo o autor:
}

De fato, o patrimônio arqueológico, entendido em seu significado mais amplo, é legalmente definido como um dos bens da União competindo aos entes federativos o dever de protegê-lo. Sua investigação [e preservação] compreende um ciclo que vai desde os procedimentos preparatórios da pesquisa, até a divulgação dos seus resultados. Os bens arqueológicos são protegidos por legislação própria - Lei Federal 3.924/61 - que normatiza seu estudo por meio da autorização de pesquisa pelo órgão representante do poder concedente, no caso o IPHAN. De direito, o patrimônio arqueológico constitui legado das gerações do passado, representadas pelos vários segmentos formadores da sociedade nacional. A geração do presente não pode interromper este legado às gerações futuras (MORAIS, 2001, p.05).

Portanto, se a ciência Arqueológica representa um legado das gerações do passado e deve ser preservada para as gerações futuras, fazendo o resgate, o estudo e a conservação, deve ser objeto de gerenciamento e gestão, como toda e qualquer ciência. Contudo, a gestão do patrimônio arqueológico, por muito tempo, foi atribuída ao Estado e entendida muitas vezes pelo próprio Estado como "cacos" e "velharias" sem qualquer utilidade. Se o ente responsável, assim o

\footnotetext{
${ }^{16}$ Atribuição que damos àqueles doutores que se esqueceram de levar na sua bagagem a humildade e a simplicidade. Estes também se dizem os "donos" da verdade absoluta e em momento algum admitem ser questionados.

17 Morais coordena a ONG Projeto Paranapanema - Projpar, que "se define como instrumento de planejamento e gestão para as investigações arqueológicas correntes no trecho paulista da bacia do rio Paranapanema, desde o final dos anos 60. É um programa interdisciplinar e interinstitucional com o propósito de identificar e analisar os cenários das ocupações humanas e seu meio ambiente. Foi criado por Luciana Palestrini em 1968. A partir de 1993, com redicionamento de seu escopo, consolidaram-se os enfoques interdisciplinares referentes ao tema território, desenvolvimento e meio ambiente. Definiram-se cenários sócio-econômicos e culturais cronologicamente pontuados" (p. 85)
} 
entendia, não era de surpreender que a sociedade civil o ignorasse e, muitas vezes, o maltratasse. No entanto, nomear o patrimônio cultural única e exclusivamente segundo os olhos da lei não é suficiente. Para Santos (1996, p. 87), "o patrimônio deve não apenas ser nomeado como público, mas deve ser reconhecido como 'índice de comunalidade, isto é, testemunho que conota algo de comum, inexoravelmente público, isto é social". O autor também ratifica a idéia de que,

graças ao avanço cultural e educacional da sociedade brasileira, esta situação está sendo modificada gradativamente, quando não pelo aumento da consciência, pela "força" de lei. É o caso da portaria 230/02, que exige entre vários procedimentos de preservação, especialmente, prática da Educação Patrimonial que segundo Horta (1999): Trata-se de um processo permanente e sistemático de trabalho educacional centrado no Patrimônio Cultural como fonte primária de conhecimento e enriquecimento individual e coletivo (p.6).

O constante incentivo às práticas educacionais voltadas à preservação e à conservação do patrimônio cultural da sociedade fortalecerá a capacidade intelectual e subjetiva das novas gerações a ponto de levar a que o olhar das gerações do presente e do futuro esteja associado às estratégias educacionais, especialmente, porque: "preservar também é gravar depoimentos, sons, músicas populares e eruditas. Preservar é manter vivo, mesmo que alterados os usos e costumes populares. É fazer, também, levantamentos de qualquer natureza, de sítios variados." (LEMOS, 1985, p.29).

A arqueologia, como ciência social, é patrimônio cultural e educacional e deve estar envolvida no processo de viver. Como afirma Baron (2004, p.150),

nossa relação com a arte produzida e reproduzida da vida. Interpreta e definem nossa relação econômica, política e social com o mundo. É como nós trabalhamos, comemos, pensamos, nos vestimos, organizamos, sentimos, escolhemos nossos amores, (...). É como entendemos a nós mesmos no mundo e como vivemos esse entendimento. Estamos o tempo todo herdando, adaptando, selecionando, construindo, passando valores e interpretações (...) (p.150). 
Enfim, todos os elementos que envolvem o patrimônio cultural vislumbram os aspectos voltados ao conhecimento gerado através de bens culturais, que devem buscar o enriquecimento individual e coletivo das sociedades locais e nacionais.

Tem-se uma dificuldade significativa de entender o que é material, quando se fala em patrimônio e se depara com o Programa Nacional do Patrimônio Imaterial/PNPI, instituído pelo Decreto $\mathrm{n}^{\circ} 3.551$, de 4 de agosto de 2000, que viabiliza projetos de identificação, reconhecimento, salvaguarda e promoção da dimensão imaterial do patrimônio cultural (IPHAN,2005).

Segundo o dicionário de língua portuguesa (HOLANDA, 2003), o imaterial é o "que não tem a natureza da matéria; não material; impalpável". A Unesco, na Convenção para a Salvaguarda do Patrimônio Cultural Imaterial, aprovada em 17 de outubro de 2003, entende por

"patrimônio cultural imaterial" as práticas, representações, expressões, conhecimentos e técnicas - junto com os instrumentos, objetos, artefatos e lugares que thes são associados - que as comunidades, os grupos e, em alguns casos, os indivíduos reconhecem como parte integrante de seu patrimônio cultural. Este patrimônio cultural imaterial, que se transmite de geração em geração, é constantemente recriado pelas comunidades e grupos em função de seu ambiente, de sua interação com a natureza e de sua história, gerando um sentimento de identidade e continuidade, contribuindo assim para promover o respeito à diversidade cultural e à criatividade humana (IPHAN, 2005).

Fundamentado nesse conceito, o Programa Nacional do Patrimônio Imaterial/PNP tem como objetivos:

- implementar política de inventário, registro e salvaguarda de bens culturais de natureza imaterial.

- Contribuir para a preservação da diversidade étnica e cultural do país e para a disseminação de informações sobre o patrimônio cultural brasileiro a todos os segmentos da sociedade.

- Captar recursos e promover a constituição de uma rede de parceiros com vistas à preservação, valorização e ampliação dos bens que compõem o patrimônio cultural brasileiro.

- Incentivar e apoiar iniciativas e práticas de preservação desenvolvidas pela sociedade ( IPHAN, 2005). 
A concretização desses objetivos depende, a exemplo do conhecimento, de programas fomentadores e estabelecedores de parcerias com instituições governamentais nos âmbitos federal, estadual e municipal; universidades, organizações não governamentais; agências de desenvolvimento e organizações privadas ligadas à cultura, à pesquisa e ao financiamento.

Entretanto, a parte prática na busca da preservação e no desenvolvimento do patrimônio imaterial encontra-se nas diretrizes, especialmente porque a exemplo da ciência comprometida com a transformação, o patrimônio imaterial, propõe-se promover a inclusão social e a melhoria das condições de vida de quem está comprometido com o patrimônio cultural imaterial. O grande avanço nessa diretriz é que se começa a romper com o que dizia Eunice Durham (1984, p.33), de que o patrimônio considerado pelas instituições oficiais é o que representa a "história das classes dominantes, os monumentos preservados são aqueles associados aos feitos e à produção cultural dessas classes dominantes. A história dos dominados é raramente preservada". Evidentemente, ainda se presencia essa realidade, porém se está, com base nesse programa, dando um grande salto e permitindo que a ciência do patrimônio cultural seja produzida pela via da inclusão social. Contudo, para que haja a inclusão social, é necessário, como contemplam as diretrizes da lei mencionada.

- ampliar a participação dos grupos que produzem, transmitem e atualizam manifestações culturais de natureza imaterial nos projetos de preservação e valorização desse patrimônio.

- Promover a salvaguarda de bens culturais imateriais por meio do apoio às condições materiais que propiciam sua existência, bem como pela ampliação do acesso aos benefícios gerados por essa preservação.

- Implementar mecanismos para a efetiva proteção de bens culturais imateriais em situação de risco.

- Respeitar e proteger direitos difusos ou coletivos relativos à preservação e ao uso do patrimônio cultural imaterial (IPHAN, 2005).

Ampliar a participação possibilita o estímulo para criar projetos, pesquisar, socializar e fazer ciência com o patrimônio cultural das camadas excluídas. Nesse sentido, Funari (2003) afirma: 


\begin{abstract}
A luta por direitos sociais, consiste em batalhar por um preservacionismo que dê conta das contradições, dos conflitos, da heterogeneidade. Tal luta não se pode restringir à esfera dos órgãos de patrimônio, pois são as forças sociais a permitir, em última instância, a contestação das exclusões já consolidadas. A ação conjunta com os agentes constitui, pois, o meio privilegiado de ação por uma preservação libertadora (p.08).
\end{abstract}

A imaterialidade carrega em sua essência a simplicidade e a espontaneidade e, por ser a manifestação das ações populares, a imaterialidade mostra-se viva, pois é patrimônio de todos e aparece significativamente nos processos de inclusão social. O Programa Nacional do Patrimônio Imaterial/PNPI não é solução, mas, como afirmou Funari, deve se constituir numa ação conjunta para poder ganhar força na preservação e libertação.

Como está expresso no Decreto $n^{\circ} 3.551$, de 4 de agosto de 2000, o registro $^{18}$ é o instrumento legal para reconhecimento e valorização ${ }^{19}$ do patrimônio cultural imaterial brasileiro (IPHAN, 2005). As formas (instrumentos) utilizadas de reconhecimento desse patrimônio permitem muitas vezes expressar a existência ou não e o grau de legitimidade do mesmo. O decreto está possibilitando dar um passo significativo em favor do patrimônio das camadas populares. Os conceitos presentes no decreto chamam atenção para:

- os saberes ou modos de fazer são atividades desenvolvidas por atores sociais conhecedores de técnicas e de matérias-primas que identificam um grupo social ou uma localidade.

- As celebrações são ritos e festividades associados à religiosidade, à civilidade e aos ciclos do calendário, que participam fortemente da produção de sentidos específicos de lugar e de território.

- As formas de expressão são formas não-lingüísticas de comunicação associadas a determinado grupo social ou região, traduzida em manifestações musicais, cênicas, plásticas, lúdicas ou literárias.

- Lugares são espaços onde ocorrem práticas e atividades de naturezas variadas, tanto cotidianas quanto excepcionais, que constituem referência para a população.

Consolidar esses conceitos é o grande desafio dos defensores do

${ }^{18}$ Os bens registrados são inscritos nos Livros de Registro dos Saberes, das Celebrações, das Formas de Expressão e dos Lugares (IPHAN, 2005).

${ }^{19}$ Grifo meu. 
patrimônio cultural do Brasil, valorizando todos os saberes, mas preservando a qualidade e a responsabilidade para com a inclusão social. Assim, conseguir-se-á combater o patrimônio cultural entendido como instrumento de alienação. Nesse contexto, a arqueologia e o meio ambiente devem ser olhados com comprometimento e responsabilidade social pelos governantes e pela população.

\subsection{RESPONSABILIDADE SOCIAL EM PROL DA ARQUEOLOGIA E DO MEIO AMBIENTE}

O direito do ambiente está intimamente ligado aos parâmetros de envolvimento da sociedade, especificamente com os fatores relacionados às ações comunitárias. O seu envolvimento diretamente com o entendimento da responsabilidade social parece óbvio, contudo, na atualidade, o conceito de responsabilidade tem assumido uma dimensão de maior interesse, seja como marketing social, seja pelo envolvimento de organizações preocupadas com a solução de vários problemas de ordem social. De uma forma ou outra, o conceito está presente e, efetivamente, tem atraído os empresários e as grandes corporações.

Pode-se dizer que a responsabilidade social deveria ser inerente à vida social das pessoas e, precisamente, às normas jurídicas. No entanto, sabe-se que todo processo de comprometimento deve estar vinculado aos compromissos e aos entendimentos da vida em sociedade. Como não se tem essa situação como conduta diária, necessita-se proclamar essa responsabilidade diariamente para efetivar o processo de conscientização e sensibilização.

A conscientização e a sensibilização dar-se-ão em nossa sociedade pela educação e pelas imposições de natureza jurídica. Nesse sentido, Luiz Solano Fleta (1995, p.20) entende a responsabilidade social como 
o conjunto de obrigações inerentes à evolução de um estado ou condição com força ainda não reconhecida pelo ordenamento jurídico positivo ou desconhecidas parcialmente, mas cuja força que se vincula e sua prévia tipificação procede da íntima convicção social de que não segui-la constitui uma transgressão da norma da cultura.

Percebe-se que o autor elucida os elementos que conduzem à responsabilidade social e provoca uma reflexão sobre os deveres e as obrigações legais, significativamente ligados aos campos da moral e da ética. Para A real concretização da moral e da ética, deve-se presenciar o exercício constante dos costumes e hábitos diários de cada coletividade. Para Solano Fleta, os costumes estão intimamente ligados à criação normativa de um grupo com competência jurídica e que, com sua uniformidade de conduta, possibilita dar origem a novas regras. Porém, o uso dos costumes e condutas deve ser atribuído a grupos carentes de ações normativas. Para que esse "uso tenha significado jurídico precisa ser recebido de fora, do Estado ou de um grupo capacitado pelo Direito" (FLETA, 1995, p24).

Ângela Fernandes (2000, p.02) registra

Basicamente, podemos definir dois tipos de uso: aquele que, com o passar do tempo, se transforma em costumes jurídicos (regulamentados), pois cumprem todas as condições materiais e formais destes. $\mathrm{E}$ o uso que, por não satisfazer determinados requisitos, não se caracteriza como costume de Direito, isto é, norma exigida, ampliada pelos mecanismos sancionadores correspondentes.

$\mathrm{Na}$ linha do raciocínio da autora, percebe-se que os costumes e, propriamente, a responsabilidade social tem uma íntima ligação com as normas e com várias obrigações de ordem prática, muitas vezes desconhecidas pelo ordenamento jurídico positivo, mas intimamente ligadas às questões da ética, a valores morais e aos princípios da conduta humana. Por isso, "a responsabilidade social é processo resultante do desenvolvimento de posturas éticas inerentes aos 
estágios de evolução de determinados grupos ou organismos sociais" (FERNANDES, 2000, p.3).

Os estágios de evolução mencionados por Fernandes refletem claramente que a preocupação social não remete apenas a momentos de indignação, com os problemas, mas a soluções que conduzem à responsabilidade das lideranças e ao compartilhamento junto aos seus membros diretivos, funcionários e colaboradores das organizações.

Para Maria Cristina Mattioli ${ }^{21}$ ( 2003),

todavia, novos temas relacionados à responsabilidade social têm surgido. As empresas não são consideradas responsáveis, atualmente, unicamente pelas ações praticadas por seus sócios, muito embora este conceito ainda seja o foco central de várias legislações. Por exemplo, a responsabilidade dos empregados e também de outros participantes na empresa é um conceito que, gradualmente, tem ganhado espaço nas legislações nacionais. Além disto, temas mais amplos, como a necessidade das empresas em tomar ativas e responsáveis medidas para minimizar a poluição, a proteção dos direitos do consumidor, frear práticas ilícitas ou observar regras éticas fundamentais e direitos humanos, também tem inspirado novas iniciativas regulatórias $(p, 2)$.

Não basta sustentar que a responsabilidade social é tarefa única e exclusiva de uma pessoa, pois está intimamente relacionada com o corpo de relações que a organização oferece ou de que participa. Nesse sentido, responsabilizar-se pelo meio ambiente não é apenas tarefa do proprietário de uma organização, mas de todos os seus colaboradores. Neste caso, os atos educativos que devem ser desenvolvidos pelas organizações, além de esclarecedores sobre a preservação ou precaução para com o meio ambiente, devem constituir uma prática constante, isto é, diariamente o cuidado para com o meio ambiente deve fazer parte da política administrativa da organização.

\footnotetext{
${ }^{20}$ Grifo meu.

${ }^{21}$ Juíza titular da $4^{a}$ vara do Trabalho de Bauru; Professora-pesquisadora do Centro de PósGraduação e Pesquisa da Universidade do Sagrado Coração; Mestre em Direito pela Universidade de Harvard; Doutora em Direito pela PUC/SP; Pós-Doutoranda em Direito pela Universidade de Harvard e no Centro de Estudos Internacionais da London School of Economics and Political Sciences
} 
Ângela Fernandes salienta que, para que 0 conceito de responsabilidade social tenha uma representação significativa na sociedade é necessário levar em consideração os itens expostos na figura abaixo:

- Trata-se de um processo relacionado a questões específicas de tempo e espaço, de evolução de pensamento e de práticas relacionadas a situações circunscritas a determinados organismos - sistemas econômicos e políticos vigentes em determinados países e suas organizações.

- Trata-se de um processo dinâmico, posto que reflita o próprio meio social, no qual se entrecruzam diversos fatores de ordem econômica, política e cultural.

- Trata-se de um processo que envolve os diversos segmentos da sociedade cidadãos, consumidores, organizações públicas ou privadas, comunidades, etc.

Fonte: adaptada do texto "A responsabilidade social e a contribuição das relações públicas" de FERNANDES, Ângela 2000, p.5.

Figura 7: Elementos de representação da responsabilidade social

O primeiro item exposto na figura demonstra claramente que a responsabilidade social não é uma prática que assume caráter de imposição, isto é, está intimamente condicionada à dinâmica do tempo e do espaço. No segundo observa-se que a autora remete a idéia de responsabilidade social intimamente aos fatores da via diária, como a economia, a política e a cultura vivenciada em cada meio social. Obviamente, no terceiro item demonstra que não há responsabilidade se não ocorrer envolvimento da sociedade civil constituída. 
Denise Frossard $(2005)^{22}$ afirma:

\begin{abstract}
Os tempos novos de propalado socialismo-democrático, ou de capitalismo responsável, emprestaram ao termo "responsabilidade social", o significado de empenho das empresas em auxiliar a sociedade na redução de suas diferenças sociais e de conservação do meio-ambiente. $\mathrm{E}$, este sentimento empresarial não veio somente por compaixão ou espírito de solidariedade. É verdade que a compaixão e o espírito de solidariedade ajudam no exercício da "responsabilidade social", mas, com certeza, as empresas, compreenderam que o crescimento dos seus resultados financeiros depende, fundamentalmente, de operarem em uma sociedade sadia. Compreenderam que a degradação social e do meio-ambiente ${ }^{23}$, com as conseqüências daí advindas, principalmente, no campo da violência e da criminalidade, termina por impor aos negócios um nível de risco elevado e os arremessa em direção ao imponderável.
\end{abstract}

A juíza esclarece que a participação das organizações é importante na melhoria das condições de vida dos membros de uma determinada sociedade. No entanto, a responsabilidade apregoada pelas organizações não se dá puramente por compaixão ou pelo espírito de solidariedade. Isso quer dizer que, quando os cidadãos estão conscientes de suas condições, passam a exigir uma maior responsabilidade das organizações da sociedade. "Onde houve ou há resistência, os consumidores vestem a camisa da cidadania e impõem a sua vontade" (FROSSARD, 2005, site). Tal vontade tem sido demonstrada com vários exemplos, de boicotes e restrições "a empresas que desrespeitam o meioambiente $^{24}$; praticam trabalho escravo; sonegam impostos ou adotam outros comportamentos reprováveis aos olhos da cidadania".

Contra essas posturas, visualizam-se movimentos gerados por organizações e empresas que possuem em sua filosofia a valorização ${ }^{25}$ do meio

\footnotetext{
${ }^{22}$ Disponível em: www.denisefrossard.com.br/ palestras/responsabilidade

${ }^{23}$ Grifo meu.

${ }^{24}$ Grifo meu.

${ }^{25}$ Hoje, de dez publicações feitas no campo da economia dos negócios, principalmente na internet, sete ou oito trazem títulos, citações ou lembranças sobre o exercício da "responsabilidade social", numa atitude que a revista Conjuntura Econômica, de junho de 2003, em matéria de capa, chamou de compra de "títulos da pobreza", para afirmar que as empresas que investem no meio ambiente e mantêm programas sociais são as que melhor conseguem colocar seus produtos no mercado. Fonte: www.denisefrossard.com.br/ palestras/Responsabilidade.
} 
ambiente; que pagam seus impostos corretamente e não admitem o trabalho escravo, nem, muito menos, o de crianças.

Portanto, a responsabilidade social não pode ser meramente confundida com palavras ou intenções que façam parte dos programas ou filosofias de organizações ou da própria lei. O vínculo desse conceito implica em procedimentos práticos que proporcionem as ações efetivas e educativas. Essas ações não surgem do nada; em especial, o Estado deve proporcionar condições para que a população exerça a cidadania. Maria Alice Antonello Londero (1999, p.05) esclarece

É direito de a comunidade participar na formulação e execução das políticas ambientais, que deve ser discutida com as populações atingidas; também, a atuação nos processos de criação do Direito Ambiental; e, ainda, a participação popular na proteção do meio ambiente por intermédio do Poder Judiciário. Necessário se faz destacar os principais instrumentos constitucionais, que estão à disposição do cidadão e da coletividade brasileira na tutela do meio ambiente:

1. Ação direta de inconstitucionalidade de lei ou ato normativo: $C F / 88$, artigos 102, inciso I, alínea a; 103; 125 , § $2^{\circ}$;

2. Mandado Segurança Coletivo: $\mathrm{CF} / 88$, artigo $5^{\circ}$, LXX;

3. Mandado de Injunção: segundo o disposto no artigo $5^{\circ}$, LXXI da CF/88 conceder-se-à mandado de injunção sempre que a falta de norma regulamentadora torne inviável o exercício dos direitos e liberdades constitucionais e das prerrogativas inerentes à nacionalidade, à soberania e à cidadania".

4. Ação Civil Pública: "é o instrumento processual adequado para reprimir ou impedir danos ao meio ambiente, ao consumidor, a bens e direitos de valor artístico, estético, histórico, turístico e paisagístico e por infrações da ordem econômica (art. $1^{\circ}$ ), protegendo, assim, os interesses difusos da sociedade".

5. Ação Popular: a Constituição Federal de 05 de outubro de 1988 assegura ao cidadão brasileiro a possibilidade de "anular ato lesivo ao patrimônio público ou de entidade de que o Estado participe (ofendendo) a moralidade administrativa, ao meio ambiente e ao patrimônio histórico e cultural (...)" (artigo $5^{\circ}$, inciso LXXIII).

Em sede infraconstitucional salienta-se a participação da população interessada na Audiência Pública do Estudo Prévio de Impacto Ambiental, conforme estabelece o artigo 225, inciso IV, da CF/88 e a Resolução CONAMA $n^{\circ}$. 9, de 3 de dezembro de 1987, bem como, a atuação de membros da comunidade em Conselhos ou Órgãos de defesa do meio ambiente. 
Abrir caminhos que objetivem a responsabilidade social para com 0 patrimônio cultural e o meio ambiente é de fundamental importância. Na exposição da autora, a lei deve cumprir um papel relevante nesse processo, até porque não é possível criar a consciência e a responsabilidade social para com o meio ambiente se os devidos instrumentos legais não estiverem à disposição dos cidadãos.

Se a lei nos remete para ações de responsabilidade social para com o patrimônio cultural e o meio ambiente, deve-se ter clareza de que as práticas diárias devem voltar-se à sociedade como um todo. "A 'responsabilidade social' nunca deveria ser uma atividade complementar ou substitutiva das atribuições do Estado, principalmente, num País onde o Estado toma pra si, exatamente para cumprir as atribuições que, por definição são exclusivamente suas" (FROSSARD, 2005). A autora continua

Compreendo a "responsabilidade social" como atividade que deve corresponder a investimentos das empresas privadas em atividades circunvizinhas, com o objetivo de melhorar o padrão profissional dos seus funcionários; de melhorar e conservar o meio-ambiente onde atuam e de fazer diferença na vida de seus consumidores, olhados também com os olhos da cidadania, acima dos interesses meramente comerciais (2005, p.5).

A juíza salienta que, apesar desse esforço da comunidade, percebe-se que o Estado age, geralmente, com ineficiência e com irresponsabilidade, não pela falta de leis, mas pela pouca compreensão e compromisso e responsabilidade política, agindo, muitas vezes, com interesses corporativos em prol dos seus dirigentes.

Assim, a arqueologia, o meio Ambiente e a responsabilidade social estão intimamente ligados no que tange à busca e à proteção dos elementos que conduzirão a sociedade para um desenvolvimento que consiga proporcionar a toda a população condições de vida e bem-estar sem, necessariamente, comprometer as gerações futuras. Por isso, cabe rever e analisar as exigências 
legais que atuam para a proteção do meio ambiente e, especialmente, neste momento, o patrimônio arqueológico. 


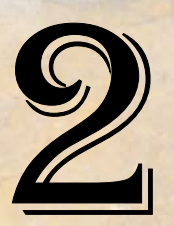

LEGISLAÇÃO SOBRE O MEIO AMBIENTE E PATRIMONNIO CULTURAL

Não se pode esquecer jamais que a lei é farol que ilumina e aponta os horizontes, não é barreira para simplesmente impedir a caminhada.

Édis Milaré 


\section{LEGISLAÇÃO SOBRE O MEIO AMBIENTE E PATRIMÔNIO CULTURAL}

\subsection{A PROTEÇÃO DO MEIO AMBIENTE E DO PATRIMÔNIO CULTURAL}

As regras sociais são mecanismos de ação do Estado, definindo um relacionamento mais equilibrado entre os interesses individuais e os coletivos na sociedade. Segundo Miguel Reale (2003 p. 59): "Todas as regras sociais ordenam a conduta, tanto as morais como as jurídicas e as convencionais ou de trato social".

Nesse sentido, a proteção do patrimônio cultural possui normas jurídicas específicas, contidas na Constituição Federal, nas leis ordinárias e também nos códigos Civil e Penal. Apresenta-se como um instrumento de proteção legal, contendo os procedimentos administrativos e técnicos de regulamentação.

A Constituição Federal de 88 estabelece no caput do artigo 2250:

Todos têm o direito ao meio ambiente ecologicamente equilibrado, bem de uso comum do povo e essencial à sadia qualidade de vida, impondose ao Poder Público e à coletividade, o dever de defendê-lo e preserválo para as presentes e futuras gerações. 


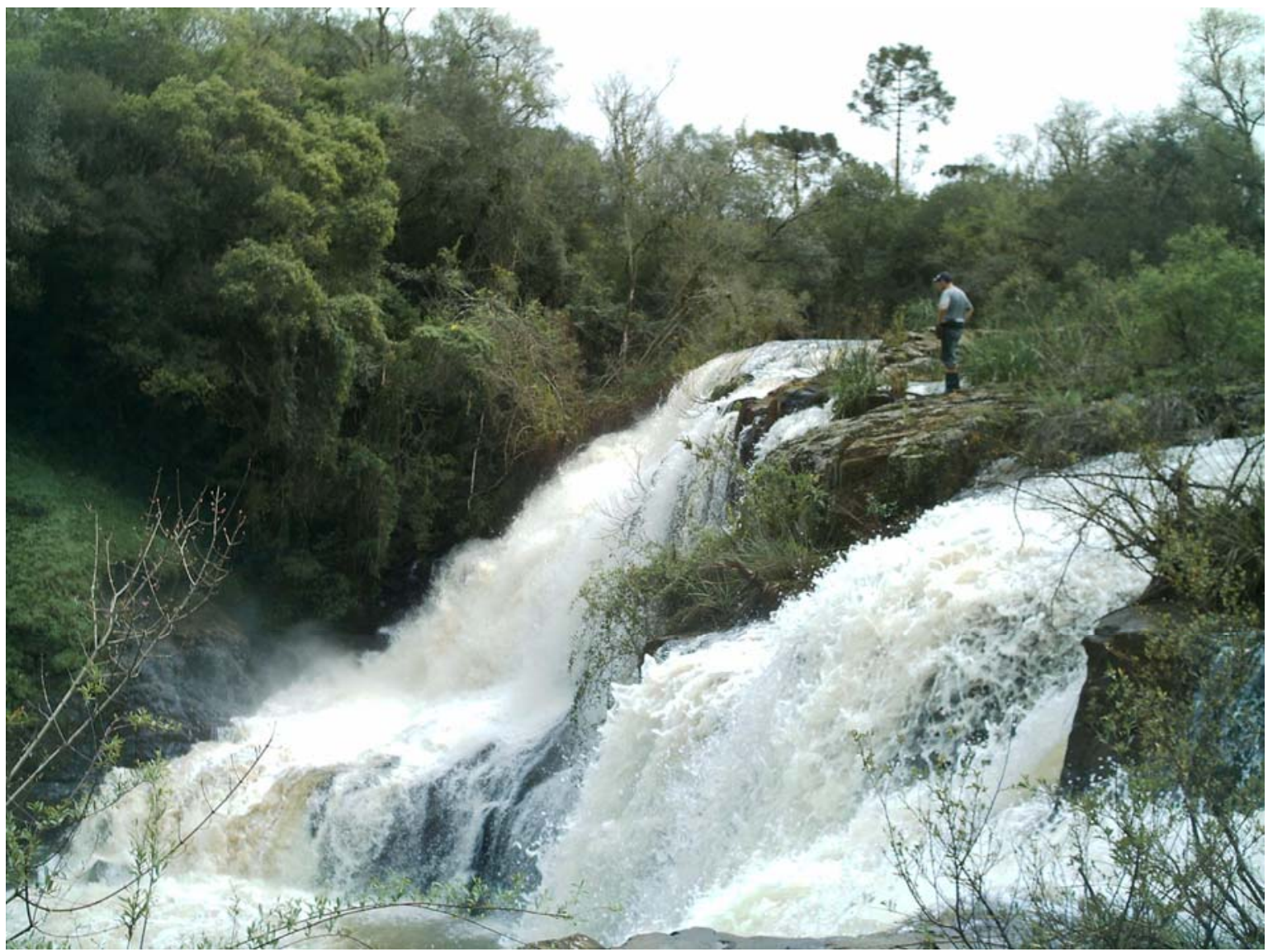

Figura 8 - o meio ambiente ecologicamente equilibrado

A questão do meio ambiente vem, ao longo do tempo, ocupando progressiva importância nos meios administrativos e jurídicos. A Constituição Federal, ao estabelecer as competências das esferas de governo, tanto comum como concorrente, explicitou com mais clareza a responsabilidade na prestação de alguns serviços, assim como para atuar em áreas específicas. O meio ambiente está sendo entendido pela ciência jurídica como um bem jurídico objetivando uma relação recíproca em razão dos interesses difusos ${ }^{26}$.

Quanto às competências no trato das questões ambientais, pode-se verificar que é dedicada especial atenção no artigo 23 da CF/88, em cujos incisos são estabelecidas como competências comuns da União, dos Estados, do Distrito Federal e dos Municípios:

\footnotetext{
${ }^{26}$ Espécie de direito subjetivo que decorre de situação fática a legitimar o ingresso em juízo para a
} sua proteção através das ações coletivas, como, por exemplo, o direito ao meio ambiente e outros. 
III - proteger os documentos, as obras e outros bens de valor histórico, artístico e cultural, os monumentos, as paisagens naturais notáveis e os sítios arqueológicos;

$\mathrm{VI}$ - proteger o meio ambiente e combater a poluição em qualquer de suas formas;

$\mathrm{VII}$ - preservar as florestas, a fauna e a flora;

IX - promover programas de construção de moradias e a melhoria das condições habitacionais e de saneamento básico;

XI - registrar, acompanhar e fiscalizar as concessões de direitos de pesquisa e exploração de recursos hídricos e minerais em seus territórios.

Por sua vez, no artigo 30 da CF de 1988, está definido que cabe aos Municípios:

I - legislar sobre assuntos de interesse local;

II - suplementar a legislação federal e a estadual no que couber;

IV - criar, organizar e suprimir distritos, observada a legislação estadual;

VIII - promover, no que couber, adequado ordenamento territorial, mediante planejamentos e controle de uso, do parcelamento e da ocupação do solo urbano;

IX - promover a proteção do patrimônio histórico-cultural local, observada a legislação e a ação fiscalizadora federal e estadual.

A Resolução Conama $n^{\circ}$ 237, de 19 de dezembro de 1997, no art. 6º estabeleceu as atribuições dos Municípios:

Compete ao órgão ambiental municipal, ouvido os órgãos competentes a União, dos Estados e do Distrito Federal, quando couber, o licenciamento ambiental de empreendimentos e atividades de impacto ambiental local e daquelas que the forem delegadas pelo Estado por instrumento legal ou convênio.

Diante desses elementos e da nova ordem que se apresenta às administrações públicas municipais, torna-se evidente a necessidade de 
estruturação das prefeituras para o atendimento da legislação ambiental vigente. Assim, a partir de 1995, aproximadamente, várias experiências municipais na gestão ambiental começaram a ser evidenciadas e apontavam para a necessidade de consolidação e fortalecimento, pois nesse ano, criava-se o Conselho de Dirigentes Municipais de Meio Ambiente (Condimma), estabelecendo uma nova ordem à integração, à capacitação e à articulação dos gestores ambientais municipais.

Destaca-se ainda, a criação da Comissão Intergestora Bipartite (CIB), integrada por representações dos órgãos do governo estadual e dos governos municipais, servindo como um fórum permanente de discussão e deliberação sobre questões relativas à gestão compartilhada nos licenciamentos e fiscalização ambiental.

Nessa comissão, estabelece-se que para a habilitação dos Municípios junto à Secretaria Estadual de Meio Ambiente(Sema) deverão eles:

I - ter implantado Fundo Municipal de Meio Ambiente;

II - ter implantado e manter em funcionamento Conselho Municipal de Meio Ambiente, com caráter deliberativo, tendo em sua composição, no mínimo, $50 \%$ de entidades não governamentais;

III - possuir, nos quadros do órgão municipal do meio ambiente, ou à disposição deste órgão, profissional legalmente habilitado para a realização do licenciamento ambiental, emitindo a devida Anotação de Responsabilidade Técnica (ART);

IV - possuir servidores municipais com competência para exercício da fiscalização ambiental;

V - possuir legislação própria disciplinando o licenciamento ambiental e as sanções administrativas pelo seu descumprimento;

VI - possuir Plano Diretor de Desenvolvimento Urbano, o Município com população superior a 20.000 habitantes, ou Lei de Diretrizes Urbanas, o Município com população igual ou inferior a 20.000 habitantes.

VII - possuir plano ambiental aprovado pelo Conselho Municipal de Meio Ambiente, de acordo com as características locais e regionais. 
Com essas condições, fica evidente a necessidade da organização administrativa e técnica da unidade de meio ambiente municipal, destacando-se a importância do Plano Ambiental Municipal como instrumento de organização administrativa. Este deve enfocar os objetivos, os instrumentos e o cronograma de implementação das medidas a serem adotadas para o controle, a correção e o monitoramento das atividades efetivas ou potencialmente causadoras de degradação ambiental ou utilizadoras de recursos ambientais.

O Município, por intermédio de sua administração, ficou responsável pela execução de atividades que atendam às demandas de sua comunidade, como saúde, educação, saneamento, lazer, e, se realizadas de forma adequada, atingiriam os objetivos propostos e uma melhor qualidade de vida.

No momento em que se questiona sobre para que servem as unidades específicas envolvendo as questões do meio ambiente, verifica-se a quantidade de problemas causados pela falta de um planejamento adequado, ou seja, de políticas que contemplem o impacto ambiental gerado em suas obras, nas questões de saneamento, na utilização dos recursos hídricos e no uso e ocupação do solo, tendo como resultado a exploração desordenada dos recursos naturais, bem como dos aspectos de isolamento e proeminência de diversas unidades administrativas.

A administração municipal deve concentrar esforços no sentido de aprimorar as atividades afins, ou seja, aquelas que repercutem em significativos ganhos na qualidade de vida das pessoas e da população.

Embora autônomo, o Município, enquanto poder público, tem competência comum com a União, Estado e Distrito Federal para dispor sobre matérias relacionadas nos artigos 23, 30 e 225 da Constituição Federal. Como exemplo, deve zelar pela guarda da Constituição; cuidar da saúde; proteger os bens de valor histórico, o meio ambiente; definir espaços territoriais para serem especialmente protegidos e exigir o estudo prévio de impacto ambiental para a instalação de obra ou atividade potencialmente causadora de significativa degradação. 
Considerando esses elementos, a Constituição Federal de 1988 preocupou-se em estabelecer mecanismos de proteção, ratificando:

Art. 215. O Estado garantirá a todos o pleno exercício dos direitos culturais e acesso às fontes da cultura nacional, e apoiará e incentivará a valorização e a difusão das manifestações culturais.

$\S 1^{\circ}$. O Estado protegerá as manifestações das culturas populares, indígenas e afro-brasileiras e das de outros grupos participantes do processo civilizatório nacional.

$\S 2^{\circ}$. A lei disporá sobre a fixação de datas comemorativas de alta significação para os diferentes segmentos étnicos nacionais.

Art. 216. Constituem patrimônio cultural brasileiro os bens de natureza material e imaterial, tomados individualmente ou em conjunto, portadores de referência à identidade, à ação, à memória dos diferentes grupos formadores da sociedade brasileira, nos quais se incluem:

$\mathrm{V}$ - os conjuntos urbanos e sítios de valor histórico, paisagístico, artístico, arqueológico, paleontológico, ecológico e científico.

Nessas circunstâncias, cabe ao Estado regular, controlar e vigiar as atividades e empreendimentos que possam causar dano ao Patrimônio Cultural. Se isso ocorrer subsiste a punição e/ou a obrigação de registro, reparação e estudos do patrimônio danificado. Não pode o órgão regulador ser omisso em relação ao acompanhamento do patrimônio, seja de que espécie for, porque a sua real função é protegê-lo e resgatá-lo de maneira lúcida e racional. Segundo Inês Virgínia Prado Soares (2007, p. 30), “a vigilância é puro exercício das atribuições que são inerentes aos órgãos diretamente responsáveis pela proteção dos bens culturais e pelo zelo dos interesses públicos".

O registro arqueológico é formado pelo resultado da ação do homem em criar ou destruir materiais que se chamam "artefatos". Esses restos de objetos deixados no solo pelo homem permitirão contar a história dos povos que tinham ou não o domínio da escrita. 
A Lei Federal $n^{\circ}$. 3.924/61 trata dos monumentos arqueológicos e préhistóricos:

Art. $1^{\circ}$ Os monumentos arqueológicos ou pré-históricos de qualquer natureza existentes no território nacional e todos os elementos que neles se encontram ficam sob a guarda e proteção do Poder Público, de acordo com o que estabelece o art. 175 da Constituição Federal.

Parágrafo único - A propriedade da superfície, regida pelo direito comum, não inclui a das jazidas arqueológicas ou pré-históricas, nem a dos objetos nelas incorporados na forma do art. 152 da mesma Constituição.

Art. $2^{\circ}-$ Consideram-se monumentos arqueológicos ou pré-históricos:

a) as jazidas de qualquer natureza, origem ou finalidade, que representem testemunhos da cultura dos paleoameríndios do Brasil, tais como sambaquis, montes artificials ou tesos, poços sepulcrais, jazigos, aterrados, estearias e quaisquer outras não especificadas aqui, mas de significado idêntico a juízo da autoridade competente;

b) os sítios nos quais se encontram vestígios positivos de ocupação pelos paleoameríndios tais como grutas, lapas e abrigos sob rocha;

c) os sítios identificados como cemitérios, sepulturas ou locais de pouso prolongado ou de aldeiamento, "estações" e "cerâmicos", nos quais se encontram vestígios humanos de interesse arqueológico ou paleoetnográfico;

d) as inscrições rupestres ou locais como sulcos de polimentos de utensílios e outros vestígios de atividade de paleoameríndios.

Por meio da arqueologia encontram-se elementos que permitem entender a vida social dos homens, ainda que levando em consideração que as atividades dos homens não se fazem, necessariamente, na superfície do solo e na arte rupestre (pinturas e gravuras realizadas nas pedras), marcada em grandes paredões de rocha.

Entretanto, para que esses vestígios sejam desvendados necessita-se da conservação do patrimônio cultural que, aparentemente, parece ser um trabalho fácil e singular, porém a situação encontrada é adversa. Observa-se junto à população, aos órgãos públicos e privados, às organizações governamentais e não governamentais que, quando abordadas sobre a questão, levantam variadas discussões acerca do tema, pois, além de haver o desconhecimento do que seja patrimônio culturalpor parte de alguns, há a desconsideração deste por outros. Nesse sentido, percebe-se que se faz necessária a atuação rígida da legislação no país. A CF/88 estabelece: 
Art. $3^{\circ}-$ São proibidos em todo o território nacional, o aproveitamento econômico, a destruição ou mutilação, para qualquer fim, das jazidas arqueológicas ou pré-históricas conhecidas como sambaquis, casqueiros, concheiros, birbigueiros ou sernambis, e bem assim dos sítios, inscrições e objetos enumerados nas alíneas b, c e d do artigo anterior, antes de serem devidamente pesquisadas respeitadas as concessões anteriores e não caducas.

Art. $4^{\circ}$ - Toda a pessoa, natural ou jurídica que, na data da publicação desta lei, já estiver procedendo, para fins econômicos ou outros, à exploração de jazidas arqueológicas ou pré-históricas, deverá comunicar à Diretoria do Patrimônio Histórico e Artístico Nacional, dentro de sessenta (60) dias, sob pena de multa de $\mathrm{Cr} \$ 10.000,00$ a $\mathrm{Cr} \$$ $50.000,00$ (dez mil a cinqüenta mil cruzeiros), o exercício dessa atividade, para efeito de exame, registro, fiscalização e salvaguarda do interesse da ciência.

Art. $5^{\circ}-$ Qualquer ato que importe na destruição ou mutilação dos monumentos a que se refere 0 art. $2^{\circ}$ o desta lei será considerado crime contra o Patrimônio Nacional e, como tal, punível de acordo com o disposto nas leis penais.

Art. $6^{\circ}$ - As jazidas conhecidas como sambaquis, manifestadas ao governo da União, por intermédio da Diretoria do Patrimônio Histórico e Artístico Nacional, de acordo com o art. $4^{\circ}$ e registrado na forma do artigo 27 desta lei, terão procedência para estudo e eventual aproveitamento, em conformidade com o Código de Minas.

Art. $7^{\circ}$ - As jazidas arqueológicas ou pré-históricas de qualquer natureza, não manifestadas e registradas na forma dos arts. $4^{\circ}$ e $6^{\circ}$ desta lei, são consideradas, para todos os efeitos bens patrimoniais da União.

Quando da entrada em vigor da Carta de 1988, acreditava-se que, dessa forma, as contravenções em relação ao patrimônio histórico e cultural do país diminuiriam, ou, quem sabe extintas; ou ainda, se ocorressem dolosamente, seus praticantes seriam punidos severamente. Isso a lei apontava como requisito básico para o fortalecimento da ação, memória ou identidade nacional e para a possibilidade de resgate da memória dos antepassados, ligando-a à presente.

A legislação federal, traduz por seu poder erga omnes, um meio coercitivo, buscando a obrigação e a imposição do cumprimento dos princípios legais de preservação da cultura e do seu patrimônio pré-histórico e histórico. Percebe-se, contudo, que o cumprimento da sentença satisfaz ao mundo jurídico, mas continua alheio ao campo propriamente ético/moral, pois, segundo Reale (2003, p.48), "para uns, a força está sempre no mundo jurídico, é imanente a ele, 
e, portanto, inseparável dele. Para outros, a coação no Direito não é efetiva, mas potencial".

Os vestígios do passado, compostos pela cultura material dos grupos pré-históricos e históricos, podem ser encontrados no solo superficialmente e/ou por meio das escavações arqueológicas sistemáticas. Assim, há a necessidade de uma informação maior dessa cultura pela população, possibilitando, preservar de maneira mais eficaz o patrimônio arqueológico, o qual deixa de ser um conhecimento exclusivo dos arqueólogos. Nesse sentido, a portaria a seguir define o que é impacto ambiental.

\subsection{IMPACTO AMBIENTAL - RESOLUÇÃO CONAMA NN. 001 DE 23 DE JANEIRO DE 1986}

A resolução do Conselho Nacional do Meio Ambiente 001/86 foi criada com o intuito de evitar impactos ${ }^{27}$ desastrosos ao meio ambiente. Para a lei, impacto ambiental é:

Artigo $1^{\circ}$ - Para efeito desta Resolução, considera-se impacto ambiental qualquer alteração das propriedades físicas, químicas e biológicas do meio ambiente, causada por qualquer forma de matéria ou energia resultante das atividades humanas que, direta ou indiretamente, afetam:

I. a saúde, a segurança e o bem-estar da população;

II. as atividades sociais e econômicas;

III. a biota;

IV. as condições estéticas e sanitárias do meio ambiente;

V. a qualidade dos recursos ambientais.

O impacto ambiental deve ser previsto antecipadamente, ao se quantificar e qualificar um adequado planejamento de obras ou atividades que

\footnotetext{
${ }^{27}$ Impacto ( do latim impactus) significa "choque" ou "colisão", vem do particípio passado do
} verbo impingere, com o sentido de impingir ou forçar contra. 
interferem no meio ambiente. Assim, podem-se prever modificações do equilíbrio ecológico, mesmo se sabendo que muitos dos efeitos poderão surgir bem mais tarde, com ou sem previsão.

\section{A Resolução Conama 0001/86 elegeu como as modalidades de} avaliação de impacto ambiental para as obras elencadas no seu art. $2^{\circ}$, nos seguintes termos:

Dependerá de elaboração de estudo de impacto ambiental e respectivo relatório de impacto ambiental - RIMA, a serem submetidos à aprovação do órgão estadual competente, e do IBAMA em caráter supletivo, o licenciamento de atividades modificadoras do meio ambiente, tais como:

I - estradas de rodagem com duas ou mais faixas de rolamento;

II - ferrovias;

III - portos e terminais de minério, petróleo e produtos químicos;

IV - aeroportos, conforme definidos pelo inciso 1, artigo 48, do DecretoLei $n^{\circ} 32$, de 18.11.66;

$\mathrm{V}$ - oleodutos, gasodutos, minerodutos, troncos coletores e emissários de esgotos sanitários;

VI - linhas de transmissão de energia elétrica, acima de 230 kV;

VII - obras hidráulicas para exploração de recursos hídricos, tais como: barragem para fins hidrelétricos, acima de $10 \mathrm{MW}$, de saneamento ou de irrigação, abertura de canais para navegação, drenagem e irrigação, retificação de cursos d'água, abertura de barras e embocaduras, transposição de bacias, diques;

VIII - extração de combustível fóssil (petróleo, xisto, carvão);

IX - extração de minério, inclusive os da classe II, definidas no Código de Mineração;

$\mathrm{X}$ - aterros sanitários, processamento e destino final de resíduos tóxicos ou perigosos;

$X I$ - usinas de geração de eletricidade, qualquer que seja a fonte de energia primária, acima de 10MW;

XII - complexo e unidades industriais e agro-industriais (petroquímicos, siderúrgicos, cloroquímicos, destilarias de álcool, hulha, extração e cultivo de recursos hídricos);

XIII - distritos industriais e zonas estritamente industriais - ZEI;

XIV - exploração econômica de madeira ou de lenha, em áreas acima de 100 hectares ou menores, quando atingir áreas significativas em termos percentuais ou de importância do ponto de vista ambiental; 
XV - projetos urbanísticos, acima de 100ha. ou em áreas consideradas de relevante interesse ambiental a critério da SEMA e dos órgãos municipais e estaduais competentes;

XVI - qualquer atividade que utilizar carvão vegetal, derivados ou produtos similares, em quantidade superior a dez toneladas por dia;

XVII - projetos Agropecuários que contemplam áreas acima de 1.000 ha. ou menores, neste caso, quando se tratar de áreas significativas em termos percentuais ou de importância do ponto de vista ambiental, inclusive nas áreas de proteção ambiental.

Os elementos supracitados mostram que quaisquer atividades modificadoras do meio ambiente dependem, para serem licenciadas, da elaboração e aprovação do EIA/RIMA ${ }^{28}$.Observa-se que a partir de meados da década de 1980, através da Resolução Conama 001/86, houve uma significativa evolução do ambientalismo brasileiro, pois até então não havia preocupações sérias e comprometidas com o meio ambiente.

O EIA é considerado, hoje, segundo Milaré (2004, p. 437),

um dos mais notáveis instrumentos de compatibilização do desenvolvimento econômico-social com a preservação da qualidade do meio ambiente, já que deve ser elaborado antes da instalação de obra ou de atividade potencialmente causadora de significância degradação, nos termos do art. $225, \S 1^{\circ}$, IV, da CF/88.

Os termos EIA/RIMA, tidos como sinônimos, representam, na verdade, de acordo com Milaré (2004, p.439), documentos distintos, pois o estudo representa uma maior abrangência que o relatório e o engloba em si mesmo. $O$ EIA

é o todo: complexo, detalhado, muitas vezes com linguagem, dados e apresentação incompreensíveis para o leigo. O RIMA é a parte mais visível (ou compreensível) do procedimento, verdadeiro instrumento de comunicação do EIA ao administrador e ao público.

${ }^{28}$ EIA - Estudos de Impactos Ambientais. RIMA: Relatório de Impacto de Meio Ambiente. 
No campo do patrimônio cultural estão contemplados no artigo $6^{\circ}$, inciso I, alínea "c", os sítios e monumentos arqueológicos, históricos e culturais da comunidade. Entretanto, Bastos (2005, p.39) registra que "não é raro encontrar EIAS e RIMAS que sequer fazem menção ao patrimônio arqueológico, executado em áreas tradicionalmente conhecidas e ricas em vestígios arqueológicos".

Artigo $6^{\circ}-\mathrm{O}$ estudo de impacto ambiental desenvolverá, no mínimo, as seguintes atividades técnicas:

I - Diagnóstico ambiental de influência do projeto completa descrição e análise dos recursos ambientais e suas interações, tal como existem, de modo a caracterizar a situação ambiental da área, antes da implantação do projeto, considerando:

c) o meio sócio-econômico - o uso e ocupação do solo, os usos da água e a sócio-economia, destacando os sítios e monumentos arqueológicos, históricos e culturais da comunidade, as relações de dependência entre a sociedade local, os recursos ambientais e a potencial utilização futura desses recursos.

Nessa perspectiva, desponta a gravidade da situação acima exposta por Bastos, pois, segundo a lei, as hipóteses regidas pela Resolução 0001/86 deveriam ser impositivas, por estarem regidas pelo princípio da obrigatoriedade. Muitos administradores interpretam a lei como pode ser, não como deve ser, ocasionando polêmicas, pois, se o empreendedor provar a insignificância do impacto ambiental, fica à mercê do ato impositivo.

Nesse sentido, foi coerente o princípio da distribuição de competências em matéria de gestão ambiental ao entregar a coordenação do processo de exigência do EIA aos órgãos estaduais competentes, exceção feita nos casos de expressa competência federal, da alçada do Ibama, ou de exclusivo interesse local, de responsabilidade dos órgãos municipais. $O$ art. $5^{\circ}$, par. único da Resolução 001/86 estabelece as competências assim:

Ao determinar a execução do estudo de impacto ambiental o órgão estadual competente, ou o IBAMA ou, quando couber, o Município, fixará as diretrizes adicionais que, pelas peculiaridades do projeto $e$ características ambientais da área, forem julgadas necessárias, inclusive os prazos para conclusão e análise dos estudos. 
Ao determinar a execução do Estudo de Impacto Ambiental, o órgão estadual competente, ou o Ibama ou, quando couber, o Município, fixará as diretrizes adicionais que, pelas peculiaridades do projeto e características ambientais da área, forem julgadas necessárias, inclusive os prazos para conclusão e análise dos estudos.

A partir da determinação das competências, cabe a esses o controle da elaboração do documento científico, não se esquecendo da necessidade da via multidisciplinar, envolvendo especialistas de várias áreas, a fim de contemplar os mais diversos estudos acerca do impacto ambiental da área direta e indiretamente atingida pelo empreendimento a ser projetado. Os objetivos do processo de licenciamento devem obedecer ao disposto no art. $5^{\circ}$ da resolução 001/86:

O estudo de impacto ambiental, além de atender à legislação, em especial os princípios e objetivos expressos na Lei de Política Nacionais do Meio Ambiente, obedecerá às seguintes diretrizes gerais:

I - contemplar todas as alternativas tecnológicas e de localização de projeto, confrontando-as com a hipótese de não execução do projeto;

II - identificar e avaliar sistematicamente os impactos ambientais gerados nas fases de implantação e operação da atividade;

III - definir os limites da área geográfica a ser direta ou indiretamente afetada pelos impactos, denominada área de influência do projeto, considerando, em todos os casos, a bacia hidrográfica na qual se localiza;

IV - considerar os planos e programas governamentais, propostos e em implantação na área de influência do projeto, e sua compatibilidade.

A elaboração de um estudo de impacto ambiental deve, portanto, obedecer à legislação vigente que regula e estabelece as diretrizes normativas do processo de implantação do empreendimento incumbindo à responsabilidade ao empreendedor e à equipe técnica pelas informações apresentadas ao órgão público, sujeitando-se às sanções civis e penais se inverídicas. 
É cabível, nessa perspectiva, rever a Portaria 007/88, em que constam as diretrizes para os projetos arqueológicos determinadas pelo SPHAN, objeto de estudo desta tese.

\title{
2.3 DIRETRIZES DE CONSERVAÇÃO - PORTARIA SPHAN Nº. 007 DE 01 DE DEZEMBRO DE 1988
}

\author{
A Portaria 007/88 tem como objetivo regulamentar a preservação, \\ proteção e controle de pesquisas arqueológicas, em complemento à Lei $\mathrm{n}^{\circ}$. \\ 3.924/61, que dispõe sobre os monumentos arqueológicos e pré-históricos.
}

Portaria $\mathrm{n}^{\circ} 007$ de 01 de dezembro de 1988.

O SECRETÁRIO DO PATRIMÔNIO HISTÓRICO E ARTÍSTICO NACIONAL, no uso das atribuições que the são conferidas pelo inciso VII do art. 16 do Regimento Interno aprovado pela Portaria Ministerial $\mathrm{n}^{\circ}$ 284, de 17 de julho de 1986, e republicado através da Portaria Ministerial $n^{\circ} 313$, de 8 de agosto de 1986, e considerando que a Lei $n^{\circ}$ 3924, de 26 de julho de 1961, submete à proteção do Poder Público, pela SPHAN, os monumentos arqueológicos e pré-históricos.

Considerando a necessidade de regulamentar os pedidos de permissão e autorização e a comunicação prévia quando do desenvolvimento de pesquisas de campo e escavações arqueológicas no País a fim de que se resguardem os objetos de valor científico e cultural localizados nessas pesquisas.

Considerando a urgência de fiscalização eficaz das atividades que envolvem bens de interesse arqueológico e pré-histórico do País.

RESOLVE:

Art. $1^{\circ}$ Estabelecer os procedimentos necessários à comunicação prévia, às permissões e às autorizações para pesquisa e escavações arqueológicas em sítios arqueológicos e pré-históricos previstas na Lei $\mathrm{n}^{\circ} 3924$, de 26 de julho de 1961.

Art. $2^{\circ} \mathrm{O}$ pedido de permissão será feito através do requerimento da pessoa natural ou jurídica privada que tenha interesse em promover as atividades descritas no art. $1^{\circ}$.

Art. $3^{\circ}$ As instituições científicas especializadas da União, dos Estados e dos Municípios deverão requerer autorização para escavações e pesquisas em propriedade particular. 
Parágrafo único. Para efeitos desta Portaria, as universidades e suas unidades descentralizadas incluem-se entre as instituições científicas de que trata o capítulo III da Lei 3924/61.

Art. $4^{\circ}$ Os órgãos da Administração federal, dos Estados e dos Municípios comunicarão previamente qualquer atividade objeto desta Portaria, informando, anualmente, à SPHAN, o desenvolvimento dos trabalhos.

A portaria em estudo estabelece uma metodologia para os projetos apresentados ao IPHAN, buscando por meio dela uma homogeneidade nas pesquisas arqueológicas. Essa homogeneidade proporcionou ao órgão gerenciador do processo uma análise mais aprimorada e minuciosa de cada projeto recebido.

Art. $5^{\circ}$ Os pedidos de permissão e autorização, assim como a comunicação prévia, devem ser dirigidos ao Secretário da SPHAN acompanhados das seguintes informações:

I. indicação do nome, endereço, nacionalidade e currículo com cópia das publicações científicas que comprove a idoneidade técnicocientífica do arqueólogo responsável e da equipe técnica;

II. delimitação da área abrangida pelo projeto

III. relação, quando for o caso, dos sítios a serem pesquisados com indicação exata de sua localização;

V. plano de trabalho científico que contenha:

1. definição de objetivos;

2. conceituação e metodologia;

3. seqüência das operações a serem realizadas no sítio;

4. cronograma da execução;

5. proposta preliminar de utilização futura do material produzido para fins científicos, culturais e educacionais;

6. meios de divulgação das informações científicas obtidas.

V. prova de idoneidade financeira do projeto;

I. cópia dos atos constitutivos ou lei instituidora, se pessoa jurídica;

VII. indicação, se for o caso, da instituição científica que apoiará o projeto com a respectiva declaração do endosso institucional.

$\S 1^{\circ}$ Serão liminarmente rejeitados os projetos que não apresentarem garantia quanto a sua execução e quanto a guarda do material recolhido.

$\S 2^{\circ}$ Os projetos em cooperação técnica com instituições internacionais devem ser acompanhados de carta de aceitação da instituição científica brasileira co-responsável indicando a natureza dos compromissos assumidos pelas partes, tanto técnicos quanto financeiros.

Art. $6^{\circ} \mathrm{A}$ SPHAN responderá aos pedidos referentes as pesquisas de campo e escavações em noventa dias, salvo se insatisfatoriamente 
instruídos, reiniciando-se a contagem do prazo a partir do cumprimento da exigência.

Parágrafo único. A decisão considerará os critérios adotados para a valorização do sítio arqueológico e de todos os elementos que nele se encontrem, assim como as alternativas de aproveitamento máximo do seu potencial científico, cultural e educacional.

Art. $7^{\circ}$ As permissões e autorizações devem ser revalidadas a cada dois anos, contados da data de emissão do respectivo instrumento.

Parágrafo único. Salvo motivo justificado, e a critério exclusivo do SPHAN, as permissões e autorizações só serão renovadas mediante a apresentação dos relatórios técnicos e a comprovação de que as informações científicas estão sendo divulgadas.

Art. $8^{\circ} \mathrm{A}$ não apresentação dos relatórios técnicos por período igual ou superior a doze meses consecutivos acarretará o cancelamento da permissão e da autorização, ficando o pesquisador impedido de prosseguir nos trabalhos de campo e a área de pesquisa liberada para novos projetos.

Art. $9^{\circ}$ os trabalhos de pesquisa serão efetuados sob permanente orientação do coordenador responsável, que não poderá transferir a terceiros os encargos da coordenação nem prévia anuência da SPHAN.

Parágrafo único. $\mathrm{O}$ arqueólogo designado coordenador dos trabalhos será considerado, durante a realização das etapas de campo, fiel depositário do material arqueológico recolhido ou de estudo que lhe tenha sido confiado.

Art. $10^{\circ}$ Do brasileiro responsável pelo desenvolvimento de pesquisas realizadas por estrangeiros exigir-se-á o disposto no art. $9^{\circ}$.

Art. $11^{\circ}$ Os relatórios técnicos devem ser redigidos em língua portuguesa e entregues ao SPHAN acompanhados das seguintes informações:

I. cadastro, segundo formulário próprio, dos sítios arqueológicos encontrados durante os trabalhos de campo;

II. meios utilizados durante os trabalhos, medidas adotadas para a proteção e conservação e descrição do material arqueológico, indicando a instituição responsável, pela guarda e como será assegurado o desenvolvimento da proposta de valorização do potencial científico, cultural e educacional;

III. planta(s) e fotos pormenorizados do sítio arqueológico com indicação dos locais afetados pelas pesquisas e dos testemunhos deixados no local;

IV. fotos do material arqueológico relevante;

V. planta(s), desenhos e fotos das estruturas descobertas e das estratigrafias reconhecidas;

VI. planta(s) com indicação dos locais onde se pretende o prosseguimento das pesquisas em novas etapas;

VII. indicação dos meios de divulgação dos resultados. 
Art. $12^{\circ}$ Terminada a pesquisa, o coordenador encaminhará ao SPHAN, em língua portuguesa, o relatório final dos trabalhos, onde deverá constar:

I. as informações relacionadas no art. 11, exceto a do item VI;

II. listagem dos sítios arqueológicos cadastrados durante $\mathrm{O}$ desenvolvimento do projeto;

III. relação definitiva do material arqueológico recolhido em campo e informações sobre seu acondicionamento e estocagem, assim como indicação precisa do responsável pela guarda e manutenção desse material.

Art. $13^{\circ}$ Esta Portaria entrará em vigor na data de sua publicação, revogadas as disposições em contrário.

Os elementos abordados pela Portaria 007/88 conduzem a se enfatizar a relevância deste instrumento para o órgão federal gestor a fim de atender aos princípios consagrados à otimização dos recursos ambientais, econômicos, financeiros e humanos. A implantação de qualquer atividade ou obra potencialmente impactante do patrimônio arqueológico deve ser submetida à análise prévia para se anteverem os riscos e eventuais impactos desastrosos.

O desafio mais decisivo encontra-se na realização do direito e do dever constitucional de universalizar o meio ambiente, o patrimônio cultural, com parâmetros de responsabilidade. De certo modo, pode-se afirmar que aí se encontra o atraso mais comprometedor do país, refletindo a falta de comprometimento com os bens difusos da sociedade brasileira.

\subsection{PROCEDIMENTOS ESSENCIAIS PARA A OBTENÇÃO DE LICENÇA} ARQUEOLÓGICA - PORTARIA IPHAN Nº. 230 DE 17 DE DEZEMBRO DE 2002

A Portaria $n^{\circ} .230 / 02$, expedida pelo IPHAN, órgão gestor federal do patrimônio arqueológico, em conformidade com a legislação, estabelece a metodologia das licenças ambientais em urgência ou não. 
Sobre a fase de obtenção de licença prévia, a lei determina a seguinte metodologia:

Art. $1^{0}$ - Nesta fase, dever-se-á proceder à contextualização arqueológica e etnohistórica da área de influência do empreendimento, através de levantamento exaustivo de dados secundários.

Art. $2^{\circ}$ - No caso de projetos afetando áreas arqueologicamente desconhecidas ou pouco conhecidas, que não permitam inferências sobre a área de intervenção do empreendimento, deverá ser providenciado levantamento arqueológico de campo ao menos em sua área de influência direta. Este levantamento deverá contemplar todos os compartimentos ambientais significativos no contexto geral da área a ser implantada e deverá prever o levantamento prospectivo de subsuperfície.

I - O resultado final esperado é um relatório de caracterização e avaliação da situação atual do patrimônio arqueológico da área de estudo, sob a rubrica Diagnóstico.

Art. $3^{\circ}$ - A Avaliação dos Impactos do empreendimento sobre o patrimônio arqueológico regional será realizada com base no Diagnóstico elaborado, na análise das cartas ambientais temáticas (geologia, geomorfologia, hidrografia, declividade e vegetação) e nas particularidades técnicas das obras.

Art. $4^{\circ}$ A partir do Diagnóstico e da Avaliação de Impactos, deverão ser elaborados os Programas de Prospecção e de Resgate Arqueológicos, compatíveis com o cronograma das obras e com as fases de licenciamento ambiental do empreendimento de forma a garantir a integridade do patrimônio cultural da área.

A fase de licença prévia destaca-se pela importância do EIA/RIMA comentado no item anterior por meio da qual há uma exposição das medidas que visam a minimizar os impactos adversos identificados e quantificados nas fases de planejamento sobre as áreas diretas e indiretamente afetadas.

Quando se fala em etapas de um projeto, é necessário, antes de tudo, pensar o ato de planejar tendo em mente os objetivos, metas e resultados esperados pela equipe, pois os problemas podem ser resolvidos em conjunto.

A pesquisa arqueológica, se realizada como estudo, não como mera aplicação, pode ser instrumento de construção emancipatória, privilegiando o conhecimento e a proteção como seu instrumento primordial. 
É essencial construir uma política científica capaz de priorizar diretrizes e ações, que devem se sobrepor a todas as pressões corporativas. Assim, fomenta-se o estratégico, por meio da legislação, visto que, "mesmo que aparente", ela tenta buscar a coerência formal, material e politicamente, assim, desmerecendo o desgaste provocado no meio público/governamental.

Com base nesses aspectos, a legislação impõe aos projetos de pesquisa arqueológica a priori a licença prévia, como visto anteriormente. Para a fase de obtenção de licença de operação, que é posterior à LI, a lei prevê:

Art. $6^{\circ}$ - Nesta fase, que corresponde ao período de implantação do empreendimento, quando ocorrem as obras de engenharia, deverá ser executado o Programa de Resgate Arqueológico proposto no EIA e detalhado na fase anterior.

$\S 1^{\circ}$ - É nesta fase que deverão ser realizados os trabalhos de salvamento arqueológico nos sítios selecionados na fase anterior, através de escavações exaustivas, registro detalhado de cada sítio e de seu entorno e coleta de exemplares estatisticamente significativos da cultura material contida em cada sítio arqueológico.

$\S 2^{\circ}$ - O resultado esperado é um relatório detalhado, que dê conta das atividades desenvolvidas em campo e laboratório e apresente os resultados científicos dos esforços despendidos, em termos de produção de conhecimento sobre a arqueologia da área de estudo. Assim, a perda física dos sítios arqueológicos poderá ser efetivamente compensada pela incorporação dos conhecidos produzidos à Memória Nacional.

Art. $7^{\circ}$ - O desenvolvimento dos estudos arqueológicos acima descritos, em todas as suas fases, implica trabalhos de laboratório e gabinete (limpeza, triagem, registro, análise, interpretação, acondicionamento adequado do material coletado em campo bem como programa de Educação Patrimonial), os quais deverão estar previstos nos contratos entre os empreendedores e os arqueólogos responsáveis pelos estudos, tanto em termos de orçamento quanto de cronograma.

Art. $8^{\circ}$ - No caso da destinação da guarda do material arqueológico retirado das áreas, regiões ou municípios onde foram realizadas pesquisas arqueológicas, a guarda destes vestígios arqueológicos deverá ser garantida pelo empreendedor, seja na modernização, na ampliação, no fortalecimento de unidades existentes, ou mesmo na construção de unidades museológicas específicas para o caso.

$\mathrm{Na}$ fase de implantação observa-se claramente a aproximação do processo executório com os critérios de gestão de uma pesquisa. Essa, desde 
que não precária, ou seja, eficiente, pode ser uma idéia adequada, à medida que se volte à oferta cada vez mais apropriada dos serviços públicos propostos.

A Portaria $n^{\circ}$. 230/02 aparece, de maneira oportuna, elencando objetivos e procedimentos a serem seguidos, esses construídos e avaliados sistematicamente.

A partir dos elementos expostos, procedimentos, fases de licença entre outros, percebe-se que a legislação brasileira busca contemplar uma política voltada à preservação ambiental e cultural dos bens patrimoniais do país. Nesse sentido, faz-se necessário contemplar uma proposta de gestão, mostrando de que forma as leis normatizadoras podem ser aplicadas a um processo de administração/gerenciamento eficaz e eficiente na área arqueológica. 


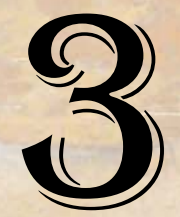

\section{ARQUEOLOGIA DE PROJETOS: OS DIFERENTES OLHARES}

Ler significa reler e compreender, interpretar. Cada um lê com os olhos que tem. $E$ interpreta a partir de onde os pés pisam. Todo ponto de vista é a vista de um ponto. Para entender como alguém lê, é necessário saber como são seus olhos e qual é sua visão de mundo. Isso faz da leitura sempre uma releitura. A cabeça pensa a partir de onde os pés pisam. 


\section{ARQUEOLOGIA DE PROJETOS: OS DIFERENTES OLHARES}

\subsection{ARQUEOLOGIA NA ÓTICA ACADÊMICA}

A arqueologia, na ótica acadêmica, sempre conduziu a ciência em questão como lugar privilegiado. Se se reportar aos diversos relatórios existentes, ver-se-á que a academia mantém uma autonomia singular para tratar o tema. 0 exemplo claro disso é o Programa Nacional de Pesquisas Arqueológicas (Pronapa), que, mesmo com os posicionamentos e exigências da legislação constituiu uma metodologia própria. A tendência foi difundida pelo Programa Nacional de Pesquisas Arqueológicas (1965-70), apoiado pelo Smithsonian Institution (EUA) e pelo Instituto de Patrimônio Histórico e Artístico Nacional e sustentou-se na metodologia de coletas superficiais, e claramente dividia seu entendimento sob as culturas antepassadas por tradições e fases.

Adriana Schmidt Dias (1995) relata:

A implementação do Programa representou um salto quantitativo e qualitativo para a arqueologia brasileira. Sua implementação possibilitou que em apenas cinco anos fossem levantados e prospectados mais de 1.500 novos sítios arqueológicos, enquadrados em um modelo cronológico e espacial de que carecia a pré-história brasileira. A partir das pesquisas do PRONAPA, em um curto período de tempo, pode-se perceber a amplitude, antigüidade e complexidade da ocupação humana no Brasil anterior à presença européia. (O PRONAPA também foi responsável por fomentar a multiplicação de centros de pesquisa arqueológica no País que passaram a formar um número cada vez maior de pesquisadores qualificados).

Esse reconhecimento é tácito e público, mesmo pelos arqueólogos mais críticos dessa linha de pensamento, como Saul Milder. Para Milder (1999, p. 9), o 
Pronapa $^{29}$, recebe muitas críticas atualmente, especialmente pós-1990, "porém cabe esclarecer que o projeto, embora criticado e possuindo limitações, deixou para as novas gerações dados substanciais sobre cronologia e dispersão de tradições arqueológicas". No entendimento de Milder, vários centros de pesquisa ligados à linha pronapiana consolidaram-se nas décadas de 1970 e 1980 com a crescente evolução de grandes obras públicas, como as hidroelétricas.

Os centros de pesquisa a que os autores se referem, indiscutivelmente, estão ligados a universidades e instituições de ensino superior. Tamanha ênfase e influência se pode ver na tendência universitária focada no grau de exigência da Portaria 07 de 1988, a qual exige nada mais nada menos do que cunhos acadêmicos de encaminhamento de projetos.

Como se vê no artigo $5^{\circ}$ da mencionada lei, a abrangência e a influência acadêmica são significativas, especialmente, por se tratar a arqueologia com a desenvoltura de projetos mostrados na cientificidade. $O$ retorno para a comunidade é entendido como atividade educacional e científica; no entanto, esses conceitos possuem diferentes olhares quando se trata de retorno aos educandos e/ou à comunidade interessada no tema.

Se seguida a ótica da educação tradicional escolar, ver-se-á que o retorno do salvamento dos sítios arqueológicos pode ficar restrito ao universo da intelectualidade acadêmica. Não há exagero nessas afirmações, se se constata por meio do número significativo de relatórios arqueológicos em que há um emaranhado de conceitos e, precisamente, de números, siglas e registros que não deixam a leitura clara e/ou esclarecedora para um cidadão comum, não the permitindo entender o significado que aquele sítio representa para a comunidade ou para o país.

\footnotetext{
${ }^{29}$ Vários autores criticam o Pronapa como Pedro Paulo Funari, André Prous e Luis Castro de Faria e este afirma enfaticamente que "a arqueologia brasileira mostra sinais evidentes de dependência e insegurança. Um destes sinais - talvez o mais grave de todos - revela-se por um espécie de renúncia ao exercício pleno de uma identidade própria auto-definida, suficiente em termos de práticas e de sustentação teórica. (...) Em face da indefinição de sua identidade (...) os métodos e técnicas ocuparam uma posição que na verdade não lhes cabe. Ao invés de simples instrumentos a serviço de uma teoria, eles se impuseram como uma condição de saber, isto é, eles se sobrepõem, quando deveriam estar subordinados".
} 
O ideal de todo conhecimento seria a compreensão clara de todos os interessados, como afirma Leonardo $\operatorname{Boff}^{30}$ (1998, p.9):

\begin{abstract}
Ler significa reler e compreender, interpretar. Cada um lê com os olhos que tem. E interpreta a partir de onde os pés pisam. Todo ponto de vista é a vista de um ponto. Para entender como alguém lê, é necessário saber como são seus olhos e qual é sua visão de mundo. Isso faz da leitura sempre uma releitura. A cabeça pensa a partir de onde os pés pisam. Para compreender, é essencial conhecer o lugar social de quem olha. Vale dizer: como alguém vive, com quem convive, que experiências tem, em que trabalha, que desejos alimenta, como assume os dramas da vida e da morte e que esperanças o animam. Isso faz da compreensão sempre uma interpretação. Sendo assim, fica evidente que cada leitor é co-autor. Porque cada um lê e relê com os olhos que tem. Porque compreende e interpreta a partir do mundo que habita
\end{abstract}

Entretanto, o desenvolvimento de diversos projetos, relatórios e resultados de pesquisas arqueológicas esteve e/ou está distante de apresentar à sociedade e ao leitor leigo uma aproximação com os resultados de um campo arqueológico, por exemplo. Em contrapartida, foi a força da cientificidade e a persistência da academia que conseguiram regulamentar em lei os aspectos necessários para disciplinar e organizar a busca do patrimônio arqueológico brasileiro. Em que pese à supremacia e À autoridade da academia diante das massas, podem-se encontrar vários projetos arqueológicos depositados nas melhores universidades do mundo em que estão resguardadas a preservação e a valorização da cultura.

Por isso, o desenvolvimento da ciência como um todo, e precisamente da arqueologia, é um todo multifacetado, porque apresenta modos e posições procedentes do pensar e do agir das diferentes sociedades, culturas e políticas. E, dialogar, comunicar ciência, tornar próximo o que é distante exige conhecimento; dessa forma, a ciência está cada vez mais distante do homem do senso comum - distante pelos muitos progressos, distante pela sua linguagem mais ou menos hermética, estando apenas acessível e inteligível àqueles que nela foram iniciados, enfim, distante pela sua complexidade e especialização

${ }^{30}$ Retirado de BOFF, Leonardo. A Águia e a Galinha: uma metáfora da condição humana. Petrópolis, RJ: Vozes,1997. 
progressiva. Essa ciência, distante do senso comum, presencia-se no delineamento do Pronapa, que já foi muito estudado pela comunidade cientifica e não cabe retomar.

Os primeiros estágios do desenvolvimento da maior parte das ciências e da arqueologia não são diferentes, tem sofrido pela competição entre várias concepções, entremeadas pelas normas da observação e pelo método científico, distinguindo-se pela incomensurabilidade de sua maneira de ver o mundo e de nele praticar a ciência. A pesquisa eficaz raramente começa antes que uma comunidade científica pense ter adquirido respostas seguras para perguntas como: quais são as entidades que compõem o universo?

Mesmo que as respostas não cheguem a exercer uma influência profunda sobre o espírito científico, auxiliam a pesquisa normal e na direção na qual esta prossegue em qualquer momento. Na pesquisa normal há a tendência vigorosa e devotada de forçar a natureza a esquemas conceituais fornecidos pela educação profissional. A ciência normal é baseada na suposição de que a comunidade científica identifica o mundo e que há disponibilidade da própria comunidade em colaborar para a realização do trabalho científico. Um problema comum muitas vezes não é resolvido em virtude da heterogeneidade dos pensamentos dos membros da comunidade científica, a qual fica desorientada, tendo de iniciar investigações extraordinárias, o que conduz a um novo conjunto de compromissos e a uma nova base para a prática da ciência. Esses episódios extraordinários são denominados "revoluções científicas", as quais são os complementos desintegradores da tradição à qual a ciência normal está ligada.

Para entender esse desenvolvimento científico, no caso da arqueologia, basta lembrar os membros do Pronapa, a arqueologia francesa, a arqueologia norte-americana; cada um conduzindo a comunidade científica a questionar a teoria científica anterior a favor da nova. Como conseqüência, modificou-se a imaginação científica, elaborando-se um trabalho diferente no interior do mundo, agora transformado.

Uma nova teoria implica uma mudança nas leis que governam a prática 
e repercute, certamente, sobre muitos trabalhos científicos já concluídos com sucesso; também requer, para sua compreensão, a reconstrução da teoria e a reavaliação dos fatos anteriores, o que raramente é concluído por um único homem. Teorias e fatos científicos não são separáveis. O mundo do cientista é tanto qualitativamente transformado como quantitativamente enriquecido pelas novidades fundamentais de fatos ou teorias.

Sobre a competição entre os membros da comunidade científica, Kuhn comenta que é o único processo histórico que favorece a rejeição da teoria anterior e a aceitação de uma nova. A história e a ciência são fontes de fenômenos aos quais se aplicam as teorias sobre o conhecimento.

Bourdieu, em sua obra O Poder Simbólico (1989, p.18), inicia o estudo sobre uma sociologia reflexiva expondo que as dificuldades encontradas na pesquisa são universais e universalizáveis, visto que é uma atividade racional, não uma busca mística, devendo estar orientada para a maximização do rendimento e um melhor aproveitamento dos recursos, inclusive do próprio tempo. O autor trata essa idéia como um alerta para evitar o que ocorre com muitos pesquisadores: a "automistificação".

Para Bourdieu toda pesquisa envolve riscos, pois há um envolvimento com o qual o pesquisador se expõe. Porém, é nessa exposição que surge a possibilidade de se tirar proveito das discussões, pois os erros e receios fazem parte do processo e o ideal "seria podermos rir-nos deles, todos ao mesmo tempo" (p.19). Logo, quando a pesquisa está ainda confusa e os receios rondam a todo o momento, Bourdieu(1989, p.20) define-a como "nascente", sendo necessário, então, que se transformem estes problemas abstratos que vão surgindo em operações científicas, pois "a eficácia de um método de pensar nunca se manifesta tão bem como na sua capacidade de constituir objetos socialmente insignificantes em objetos científicos".

Assim, se dá a relação teoria e prática, porém, tendo em vista que os princípios fundamentais desta prática ocorrem ao lado de um guia ao mesmo tempo em que o pesquisador deve ter a responsabilidade direta sobre a mesma, 
pois, para se adquirir o modus operandi (modo de produção científico), é necessário ver operar o habitus científico, como ele reage perante opções práticas (ex:: questionários/amostragem). Esses habitus não são regras, mas atitudes certas, tomadas no momento certo (p.20-23). Bourdieu considera ainda que uma prática sem teoria (pedagogia do silêncio) é maior numa ciência em que não estão explicitados/codificados os conteúdos, saberes, modos de pensamento e ação.

Outro fator relevante tomado por Bourdieu é o trabalho de pesquisa que se processa através de um pensar racional, ou seja, pensar o mundo social de maneira realista, pois a divisão teoria/metodologia constitui uma oposição da divisão social do trabalho científico, visto que "não se pode reencontrar o concreto combinado em duas abstrações" (p. 24). O autor sugere que se pode pensar relacionalmente fazendo, na fase indutiva, um quadro de caracteres do conjunto de agentes/instituições da pesquisa e, após, agrupar as características equivalentes em termos de presença ou ausência. O próprio método de amostragem, segundo Bourdieu, deve se impor em razão da construção deste objeto; portanto, deve estar relacionado a ele, não devendo cair numa rotina cultural, num monoteísmo metodológico [pois] (...) "as condenações metodológicas são uma maneira de tornar a necessidade em virtude, de fingir que se ignora (...) o que realmente se ignora" (p.25).

Bourdieu expõe que não é necessário rigidez, mas rigor na pesquisa, além de liberdade extrema, extrema vigilância das condições de utilização das técnicas, sendo necessário mobilizar todas as utilizáveis na coleta dos dados. É preciso construir este objeto de pesquisa aos poucos e formar espaços sociais que constituem a realidade do mundo social, não podendo o pesquisador cair na armadilha do objeto pré-construído (aquele que lhe interessa), sem saber o porquê do seu interesse por ele.

Portanto, se o real é relacional, não se deve julgar que se sabe tudo sobre algo caso não se conheça sua relação com o todo. Bourdieu levanta uma questão ambígua: "Vale mais a pena estudar o conjunto de elementos do objeto construído ou um fragmento, como sugere o positivismo?" 
Outro fator que Bourdieu refere é o valor de a dúvida radical estar presente na pesquisa, pois para construir um objeto científico é preciso romper com o senso comum (p. 34), visto que os problemas são socialmente produzidos na construção da realidade social e o surgimento de associações, ligas, movimentos de classes tornou os problemas privados públicos/sociais, cuja produção é objeto do sociólogo.

Uma oposição que a pedagogia da pesquisa apresenta é que deve transmitir instrumentos de construção da realidade, problemáticas, conceitos, técnicas, métodos e, ao mesmo tempo, uma formidável atitude crítica, uma tendência para pôr em causa esses instrumentos. $O$ pesquisador deve tomar 0 dado como ele se dá naturalmente, pois trabalhar num objeto já construído tornase difícil pelo fato de o progresso teórico gerar dificuldades metodológicas.

Bourdieu mostra que essa reflexidade obsessiva é condição de uma prática reflexiva rigorosa; assim, para se fazer ciência muitas vezes é preciso evitar as aparências da cientificidade, contradizendo as normas em vigor e desafiando os critérios correntes do rigor científico, objetivando os esquemas do senso prático para impedir que a razão prática contamine a razão científica. Dessa forma, evita-se tratar como instrumento de conhecimento o que deveria ser objeto de conhecimento.

Uma pedagogia de pesquisa apresenta também obstáculos, como o conformismo dos professores (educação como mera reprodução escolar), a constatação de que as produções intelectuais saídas do ensino corrente da sociologia são condenadas a voltar a ele, e a perpetuação de oposições fictícias entre autores, métodos e conceitos. Pode-se afirmar que teoria sem prática é igual à metodologia sem conceito.

O que se vê nas universidades é um culto escolar dos clássicos, contrário a uma verdadeira história crítica das ciências. Estudantes e professores percorrem caminhos já conhecidos. Constata-se a submissão aos hábitos de pensamento, que podem conduzir à ingenuidade e a uma tradição douta, que atribui o nome de ciência a uma simples transcrição do discurso do senso comum. 
Nesse sentido, a pesquisa arqueológica na ótica acadêmica não está em negligenciar o já-construído, mas em adequá-lo às necessidades da sociedade e, precisamente, fugir das análises simplificadas e simplistas de observação dos "caquinhos" da arqueologia.

A provocação mais recente aos desafios acadêmicos para a arqueologia tem sido a relação estabelecida entre a arqueologia exigida na legislação, como se viu no item anterior, e precisamente o mundo acadêmico.

\subsection{ARQUEOLOGIA DE CONTRATO}

A arqueologia, como ciência, preocupa-se com os vestígios materiais do passado. Que relação estabelece com o contrato e com uma diferente forma de contrato? É conveniente que se entenda o conceito de contrato e, precisamente, a sua importância nas relações contemporâneas.

Afirmar ou buscar interesses remete à vinculação de relações que, em grande parte, são harmoniosas, porém em outra, são conflituosas. Nesse sentido, a figura do contrato surge nas relações da sociedade para firmar e consolidar as relações. Para Vicente de Paula Barreto (2006, p.159), o contrato é

o instrumento por excelência, mediante o qual duas ou mais pessoas cooperam entre si, a fim de obter cada uma um determinado proveito em seu favor, ou um proveito para uma das partes da relação jurídica. A palavra contractus, de origem latina, significa unir, contrair. Trata-se da expressão elíptica de negotium contractum ou contractus negotii. O seu fundamento é a vontade ${ }^{31}$, e o seu efeito a criação de direitos e obrigações para as partes.

No que tange às instituições, o contrato, segundo Antonio de Paulo ${ }^{32}$ (2002, p.86), é "todo e qualquer ajuste entre órgãos ou entidades da

\footnotetext{
${ }^{31}$ Grifo meu

${ }^{32} \mathrm{O}$ autor vai buscar este conceito na Lei de Licitações, art. $2^{\circ}$, parágrafo único.
} 
administração publica e particulares em que haja um acordo de vontades ${ }^{33}$ para a formação de vínculos e a estipulação de obrigações recíprocas, seja qual for a denominação utilizada".

Em ambos os conceitos observam-se que a expressão "vontade" dimensiona e sustenta o posicionamento e os interesses dos contratantes. A vontade representa mentalmente um ato que pode ou não ser praticado em obediência a um impulso ou a motivos ditados pela razão, ou pelo sentimento que incita alguém a atingir o fim proposto por esta faculdade; aspiração; anseio; desejo. (AURÉLIO, 2003).

Nesse sentido, a aproximação da arqueologia ao mundo do contrato está mais sustentada nos parâmetros da legalidade do que propriamente nas vontades e particularidades dos pesquisadores. Contudo, os arqueólogos que se propõem a conviver com essa realidade têm sustentado seus argumentos na legalidade e, propriamente, na coletividade do contrato. Isso remete a entender que para a arqueologia de contrato não estão em jogo somente as vontades individuais, mas o conceito de contrato social. É claro que a maioria que estÁ trabalhando e atuando nessa área sequer entende a ótica conceitual do contrato social. Parte-se do real objetivo deste trabalho, dimensionar para o debate e entender que o contrato social na arqueologia de contrato não é entendido como na tradição de Rousseau, na qual em que todas as ações provenientes dos indivíduos são boas, mas se corrompem e/ou são distorcidas nas ações sociais e coletivas. Para a arqueologia de contrato, deve-se observar a função social do contrato. Nesse sentido, Barretto (2006, p.162) esclarece:

\footnotetext{
A função social do contrato, portanto, na acepção mais moderna, desafia a concepção clássica de que os contratantes tudo podem fazer, porque estão no exercício da autonomia da vontade. O reconhecimento da inserção do contrato no meio social e da função como instrumento de enorme influência na vida das pessoas possibilita um maior controle da atividade das partes. Em nome do princípio da função social do contrato se pode, por exemplo, evitar a inserção de cláusulas que venham injustificadamente prejudicar terceiros, ou mesmo proibir a contratação tendo por objeto determinado bem, em razão do interesse maior da coletividade.
}

\footnotetext{
${ }^{33}$ Grifo meu.
} 
No caso mencionado, a arqueologia é a ciência que lida com um objeto que, especificamente, pela natureza legal e pela vontade histórica e social, não é propriedade de um pesquisador, empreendedor, nem muito menos, de um proprietário; ela é, sim, um componente da sociedade, pela qual se deve zelar. Contudo, como os interesses para com essa ciência são diversos, o real guardião passa a ser o Estado. Com isso, as vontades, que antes se sustentavam na individualidade e no bel prazer dos interesses de pesquisadores isolados ou por manifestações estéticas e econômicas, têm, agora, de ser dimensionadas na ótica da responsabilidade social.

É claro que o interesse não é sustentar uma análise mais aprofundada das expressões jurídicas e das próprias relações jurídicas ${ }^{34}$, porém é importante que essa base seja ressaltada, até porque, como foi mencionado nos capítulos anteriores, os aspectos legais e as responsabilidades sociais que sustentam a política nacional de meio ambiente e todas as normas e leis que orientam para a preservação do patrimônio arqueológico e cultural brasileiro, devem ser respeitados.

Seria pretensão desconsiderar o tema arqueologia de contrato e,propriamente, a denominação. Uma das autoridades da arqueologia no país, o Dr. Rossano Lopes Bastos, discorre sobre o tema em capítulo do seu mais recente livro Arqueologia na ótica institucional: IPHAN, contrato e sociedade (2007). O autor explica:

Analisando o campo científico-institucional da Arqueologia no Brasil hoje, fica evidente que estamos diante uma crise semelhante às revoluções como mudanças de concepção de mundo. Conseqüentemente, o mundo da pesquisa arqueológica encontra-se dentro desta perspectiva, com anomalias de difícil convivência ${ }^{35}$. Assim, isso nos faz examinar as pesquisas arqueológicas do passado a

\footnotetext{
${ }^{34}$ As relações jurídicas subdividem-se em dois grandes grupos, as relações de apropriação e as de cooperação. As de apropriação dizem respeito ao fenômeno pelo qual se toma alguma coisa como sua, excluindo as demais de qualquer poder jurídico sobre ela. As de cooperação, como o próprio nome quer significar, são as que se formam entre duas ou mais pessoas, em caráter transitório, pretendendo a obtenção de uma ou mais pessoas, em caráter transitório, pretendendo a obtenção de uma ou mais prestações, que venham a lhes satisfazer uma necessidade ou comodidade. (BARRETTO, 2006, p.159)

${ }^{35}$ Grifo meu
} 
partir da perspectiva da Arqueologia Contemporânea, e podemos nos sentir "tentados" a proclamar que quando mudam os paradigmas, mudam, com eles, o próprio mundo. $(2007$, p.74)

As anomalias a que Bastos se refere podem conduzir a uma interpretação maliciosa ou propriamente catastrófica. Contudo, a "tentação" a que se refere o autor é, talvez, a própria condição que a arqueologia de contrato está deixando latente, não propriamente para mudança de paradigmas e, sim, para a aquisição de ganhos financeiros num curto espaço de tempo e o confronto direto com os grandes empreendimentos que marcam o país. Nesse sentido, "o aporte acadêmico, isolado, da arqueologia brasileira já demonstrou ser inadequado para responder as demandas que estão amparadas na Arqueologia de Contrato" (BASTOS,2007,p. 62). Continua o autor:

O olhar arqueológico hoje tem prazos, recursos financeiros limitados pelas exigências da norma legal, e, principalmente, vários outros atores sociais foram incorporados na dinâmica do Patrimônio Arqueológico.

É dentro deste contexto, com imperativos de ordem temporal e financeira que se procurou adequar antigas práticas e métodos arqueológicos às exigências deste novo campo de trabalho.

Contudo, podemos observar que a demanda arqueológica advinda através de desenvolvimento desigual, assimétrico e excludente, tem levado, também, a situações de extremo desconforto, onde o produto final do trabalho arqueológico de contrato tem provocado "mal estar" entre os arqueólogos (p.63).

Os novos atores referidos pelo autor geram uma curiosidade e, sobretudo, exclamações, não precisamente a quem faz, mas como faz a arqueologia. Neste caso, a diferenciação entre a arqueologia de contrato e a acadêmica não está precisamente na composição, formação ou estrutura do projeto, pois isso, como já mencionado na portaria 07/88, ela orienta e, por que não, manda por força de norma.

Nessa ótica, o que diferencia os projetos de arqueologia acadêmicos ao dos contrato é a tônica de seu gerenciamento e, sobretudo, a prioridade definida pelos seus pesquisadores. Mas como gerenciar? Como fazer com que os projetos e as pesquisas devolvam às comunidades leigas resultados rápidos? Esse é o 
dilema maior da academia, acostumada que está a pesquisas longas e resultados restritos ao seu universo.

Não se quer dizer que a arqueologia de contrato é a panacéia e a salvação para ciência arqueológica, porém quem convive com os dois universos sabe que o grau de exigência, é nítido e diferenciado quanto ao tempo e aos resultados. Contudo, quanto à qualidade, não podem ser atribuídos méritos maiores para a arqueologia acadêmica ou para a arqueologia de contrato. Em ambas as situações encontram-se excelentes trabalhos como também péssimos trabalhos. Portanto, a pergunta é: Como conseguir diferenciar se o projeto $X$ é melhor do que o Y? A diferenciação e, precisamente, o grau de qualidade fundamentam-se na gestão do projeto.

Bastos referencia que o controle e o desenvolvimento exercido pelas elites e, precisamente, por ações focadas na unilateralidade do conhecimento e nos interesses de concentração econômica trouxeram sérias conseqüências na sociedade e, "no campo arqueológico, estes significados encontram ressonância, em pares e instituições arqueológicas que pensam e entendem estar acima da lei e da norma" (BASTOS, 2007, p 64).

Essa é uma das situações que provoca muito desconforto na ciência arqueológica, no que se concorda com Bastos (2007, p.64) quando afirma que "o positivismo, ${ }^{36}$ de um lado, e o individualismo, de outro, são fatores que ao longo da história arqueológica, muitas vezes, moldaram os esforços teóricos, os códigos e as práticas profissionais". É claro que a ciência arqueológica não ficaria fora desse envolvimento, até porque todas as instituições de formação científica do país, foram, e em grande parte são, controladas por interlocutores do positivismo e do individualismo. Por isso, para Bastos (2007, p.76-7):

\footnotetext{
${ }^{36}$ O positivismo é entendido aqui como o "termo que afirma que o valor do mundo objetivo, dado, posto ou real, ao meramente pensado, desejado ou valorizado por um sujeito qualquer. Daí a utilização do termo positivismo para designar correntes filosóficas que se caracterizam pela adesão â realidade e consequentemente, pela rejeição de especulações não justificáveis por uma referência ao lado empírico"( BARRETTO, 2006, P.642).
} 
Investigar as condições contemporâneas da Arqueologia de Contrato remete, necessariamente, a esfera pública, seja através do IPHAN, Museus, Universidades, órgão ambiental, seja através da delegação de competências especificas de estudos e pesquisas que Estado através do IPHAN, partilha com arqueólogos junto à iniciativa privada, segmentos acadêmicos, Museus, Institutos e Centros de Pesquisa. É preciso assinalar a dissonância do entendimento de competência entre as várias esferas políticas e os vários órgãos estatais no cumprimento das obrigações legais em relação ao patrimônio Arqueológico e Cultural.

De forma muito recente gestões integradas entre IBAMA, órgãos ambientais estaduais, municipais e o IPHAN têm obtido relativo sucesso, na preservação do Patrimônio Arqueológico e Cultural.

Nesse sentido, é quando o volume de projetos é encaminhado para os órgãos licenciadores que a arqueologia ganha notoriedade em escala de mídia e marketing visual. Com isso, as dissonâncias de competência, interpretação e, sobretudo, os resultados são, de certa forma, normais.

Pesquisar um bem público para interesses privados ${ }^{37}$ foi, inicialmente, e está sendo, de certa forma, para alguns arqueólogos a linha da arqueologia de contrato.

Disserta Mourão (2007, p.90):

O desfrute venha ocorrendo de acordo com o "espírito" do legislador constituinte. Ao contrário, em nossos estudos verificamos que o IPHAN, na condição de "proprietário" do bem arqueológico, tem permitido a empresas realizar pesquisas arqueológicas em moldes exclusivamente mercantis. Desse modo, estaria prevalecendo o individualismo, possivelmente motivado por interesses puramente econômicos dos "empresários da arqueologia". Além disso, com esse procedimento, o órgão estatal responsável somente pela administração do bem ambiental, bem este que pertence a toda a coletividade, está favorecendo a pulverização da arqueoinformação gerada pelas pesquisas de arqueologia preventiva. Tem-se, assim, um saber segmentado, restrito aos arquivos dos órgãos licenciadores e dos escritórios das empresas especializadas. Contrariamente ao que a atitude do IPHAN sugere, a livre iniciativa é um fundamento do liberalismo econômico que a nossa Constituição não adotou de modo irrestrito. Opõem-se a esse fundamento princípios como a soberania, a defesa do consumidor, a defesa do meio ambiente, a função social da propriedade, dentre outros previstos no art. 170 (FIORILLO, 2004b, p. 17). Dessa forma, a Constituição Federal brasileira estabelece limites à ação particular, priorizando a coletividade em detrimento do indivíduo, adotando como fundamento do Estado Democrático de Direito os valores sociais da livre iniciativa, e não a livre iniciativa por si mesma.

${ }^{37} \mathrm{O}$ privado aqui está caracterizado como sendo tanto as empresas de consultoria em arqueologia como os empreendedores, que devem cumprir as resoluções legais para instalação de empreendimentos impactantes ao meio ambiente. 
Essa perspectiva é confirmada na legislação derivada, que atribuiu, às entidades do setor público não estatal e sem fins lucrativos, legitimidade jurídica especial para a promoção e a tutela dos princípios previstos na Carta.

\title{
O autor procura enfatizar as ações dos empreendimentos impactantes,
} os quais abriram um "nicho ${ }^{38}$ de mercado", que precisamente, está mencionado, pela sua importância, na legislação brasileira, abordada anteriormente, beneficiando a iniciativa privada, que o tem aproveitado. Harvey (1989, p.151.) refere que isso é fruto da acumulação flexível ${ }^{39}$ e arremata:

\begin{abstract}
O acesso ao conhecimento científico e técnico sempre teve importância na luta competitiva; mas, também aqui, podemos ver uma renovação de interesse e de ênfase, já que, num mundo de rápidas mudanças de gostos e necessidades e de sistemas de produção flexíveis (em oposição ao mundo relativamente estável do fordismo padronizado), o conhecimento da última técnica, do mais novo produto, da mais recente descoberta científica, implica a possibilidade de alcançar uma importante vantagem competitiva. O próprio saber se torna uma mercadoria-chave, a ser produzida e vendida a quem pagar mais, sob condições que são elas mesmas cada vez mais organizadas em bases competitivas. Universidades e institutos de pesquisa competem ferozmente por pessoal, bem como pela honra de patentear primeiras novas descobertas científicas (...) A produção organizada de conhecimento passou por notável expansão nas últimas décadas, ao mesmo tempo em que assumiu cada vez mais um cunho comercial (como o provam as incômodas transições de muitos sistemas universitários do mundo capitalista avançado de guardiãs do conhecimento e da sabedoria para produtores subordinados de conhecimento a soldo do capital corporativo).
\end{abstract}

\footnotetext{
${ }^{38}$ Nicho, segundo o Dicionário Aurélio é segmento restrito do mercado não atendido pelas ações tradicionais de marketing e que, gerencialmente, oferece novas oportunidades de negócio.

${ }^{39}$ A acumulação flexível, como se chama, é marcada por um confronto direto com a rigidez do fordismo; apóia-se na flexibilidade dos processos de trabalho, dos mercados de trabalho, dos produtos e padrões de consumo. Caracteriza-se pelo surgimento de setores de produção inteiramente novos, por novas maneiras de fornecimento de serviços financeiros, por novos mercados e, sobretudo, por taxas altamente intensificadas de inovação comercial, tecnológica e organizacional. A acumulação flexível envolve rápidas mudanças dos padrões do desenvolvimento desigual, tanto entre setores como entre regiões geográficas, criando, por exemplo, um vasto movimento no emprego no chamado "setor de serviços", bem como conjuntos industriais completamente novos em regiões até então subdesenvolvidas (tais como a "Terceira Itália", Flandres, os vários vales e gargantas do silício, para não falar da vasta profusão de atividades dos países recém-industrializados). Também envolve um novo movimento, que se chama de "compressão do espaço-tempo" no mundo capitalista - os horizontes temporais da tomada de decisões privada e pública se estreitaram, enquanto a comunicação via satélite e a queda dos custos de transporte possibilitou cada vez mais a difusão imediata dessas decisões num espaço cada vez mais amplo e variegado. (HARVEY, 1989, p. 140).
} 
A renovação e o interesse mencionados pelo autor remeteram à ciência arqueológica para fora das linhas da lei, passando a ser entendida como uma mercadoria forte e interessante. Talvez seja essa a grande dúvida e a crise existencial de alguns arqueólogos da academia, pois são "contra" a arqueologia de contrato. Versando sobre a essência teórica e o trato do material arqueológico, à academia sobram notoriedade e excelência.

Entretanto, as relações de mercado, contempladas por alguns arqueólogos e por empreendedores, geram complexidade e confusões porque, além de realizar as fases das pesquisas, é necessário dar respostas a um ente (empreendedor) que precisa das autorizações e licenças para continuar seu “investimento". Nesse caso, Harvey $(1993$, p.) está mais atual do que nunca ao mencionar que "o próprio saber se torna uma mercadoria-chave, a ser produzida e vendida a quem pagar mais, sob condições que são elas mesmas cada vez mais organizadas em bases competitivas".

A lei estabelece as normas para o zelo e a proteção do bem público. A arqueologia e a responsabilidade não podem ser integralmente do IPHAN, porém há a necessidade de encarar este órgão como zelador e protetor deste patrimônio. Aos que se desafiam a percorrer, seja academicamente, seja por meio da iniciativa privada, as pesquisas arqueológicas devem estar cientes de suas responsabilidades legais. Por isso, "é importante lembrar que o conhecimento científico, incluindo o arqueológico, nunca é neutro e demanda opções de vários tipos". (BASTOS, 2007,p.65). Com isso, a representação dos universos da arqueologia de contrato e a arqueologia acadêmica assemelham-se muito. Muitos arqueólogos de contrato apoderam-se dos recursos e do material arqueológico sem qualquer divulgação ou responsabilidade social de extroversão. Quanto à arqueologia acadêmica, também negligencia os saberes, restringindo-os ao seu universo particular e destinando grande parte dos recursos dos projetos a "qualificações e viagens pessoais". 
Por isso, Bastos (2007, p. 65) afirma:

Do ponto de vista, das representações sociais sobre "o fazer arqueológico", o arqueólogo é entendido como uns caçadores de tesouros escolarizados, que trabalha em proveito próprio, carregam com os tesouros achados e largam para trás um enorme buraco, sem que isto tenha o menor impacto social positivo na vida das pessoas do lugar, com que razão se sente usurpada.

Essa afirmação pode ser exagerada, mas possui um caráter de impacto e de absorção da consciência coletiva sobre a qual não há dúvida. Contudo, a realidade é dura e muitas vezes cruza/bate/confronta com o pensamento dos "PHDeuses", os quais se nutrem de uma visão estreita, dita por profissionais com larga experiência na área. É nesse sentido que Bastos (2007, p.78) discorre:

\begin{abstract}
a ação dos pesquisadores sobre os bens arqueológicos encontra não uma lacuna entre palavras e atos, mas uma inversão de sentido: o que deveria ser público, em larga medida torna-se privado, e pode ser medido pela prática enraizada de alguns pesquisadores da arqueologia em omitir dados em relação ao patrimônio arqueológico, que vão desde o não registro dos sítios arqueológicos, conforme a norma legal, até a resistência em tornar transparente ao órgão normalizador e fiscalizador os custos financeiros envolvidos na pesquisa de contrato de um bem público, como o é o bem arqueológico.
\end{abstract}

O autor utiliza uma lógica de argumentos que é uma visão de síndrome fatalista $^{40}$, presentes no meio arqueológico: "As coisas são como são, como foram ontem e como serão amanhã. Somente o presente conta, e não um presente pleno, mas aquele comecinho, individual, que é dado pelo empobrecimento das possibilidades da vida" (BASTOS, 2007, p.78).

\footnotetext{
${ }^{40}$ Martin-Baró (1993) descreveu o que ele chamou de "síndrome fatalista" na América Latina, cuja conseqüência mais nefasta é barrar a noção de um tempo histórico na consciência e ação de sujeitos sociais. Neste tipo de síndrome, tanto seres humanos como objetos sociais simplesmente seguem mudanças de qualquer ordem não são esperadas, a não ser aquelas que pertencem ao curso dado da vida. MARTIN-BARÓ, I. Sistema, grupo y poder: psicologia social desde Centroamerica II. San Salvador : UCA, 1993.
} 
O pensamento do autor induz a uma crise, especificamente, pela má intencionalidade ou, precisamente, pela falta de clareza no processo de gestão. Prefere-se encarar de uma forma mais otimista e apostar na segunda opção, no entanto não se pode desconsiderar o que Bastos afirma, até porque é nos momentos de crise e na falta de identidade que os oportunistas aparecem.

\begin{abstract}
Dentro desta perspectiva, ancorada no conceito da "síndrome fatalista", que nos impõe um reducionismo obscuro no entendimento das práticas e responsabilidades éticas, a arqueologia de contrato por se tratar de um campo de trabalho relativamente "novo" e sem normalização e balizamentos técnicos explicitados a contento, impõe uma conduta aos arqueólogos de caráter moral, muito mais próxima da ética clássica, do cidadão virtuoso, do que da ética moderna ou pós-moderna, que encerra posturas mais arrojadas em defesa dos bens públicos e do interesse verdadeiramente coletivo (BASTOS, 2007, p.78).
\end{abstract}

Dentro de um pensamento mais arrojado, como estruturar avanços em algo que pouco se conhece, não no sentido de saber o que é um bem público, como é a arqueologia, mas o que fazer com esse bem público? A problemática fundamenta-se precisamente nas características e nos fundamentos da gestão dos projetos de arqueologia. Porém, esta, tem de ter claro que o objeto de sua gestão é bem público, de caráter não renovável, portanto, diz respeito ao coletivo, e o papel a ser desempenhado pelo arqueólogo é o de garantir a melhor forma de proteção ao patrimônio arqueológico (BASTOS, 2007,78).

Dessa forma, pode-se afirmar, com segurança, que não se trata de colocar a arqueologia estritamente acadêmica em segundo plano, nem, muito menos de desconsiderar a arqueologia de contrato, do que realmente se precisa é que ambos os caminhos se cruzem de uma forma dialética e proativa. Nesse sentido, a gestão demonstrará a possibilidade de que este vínculo é possível por meio da arqueologia preventiva. 


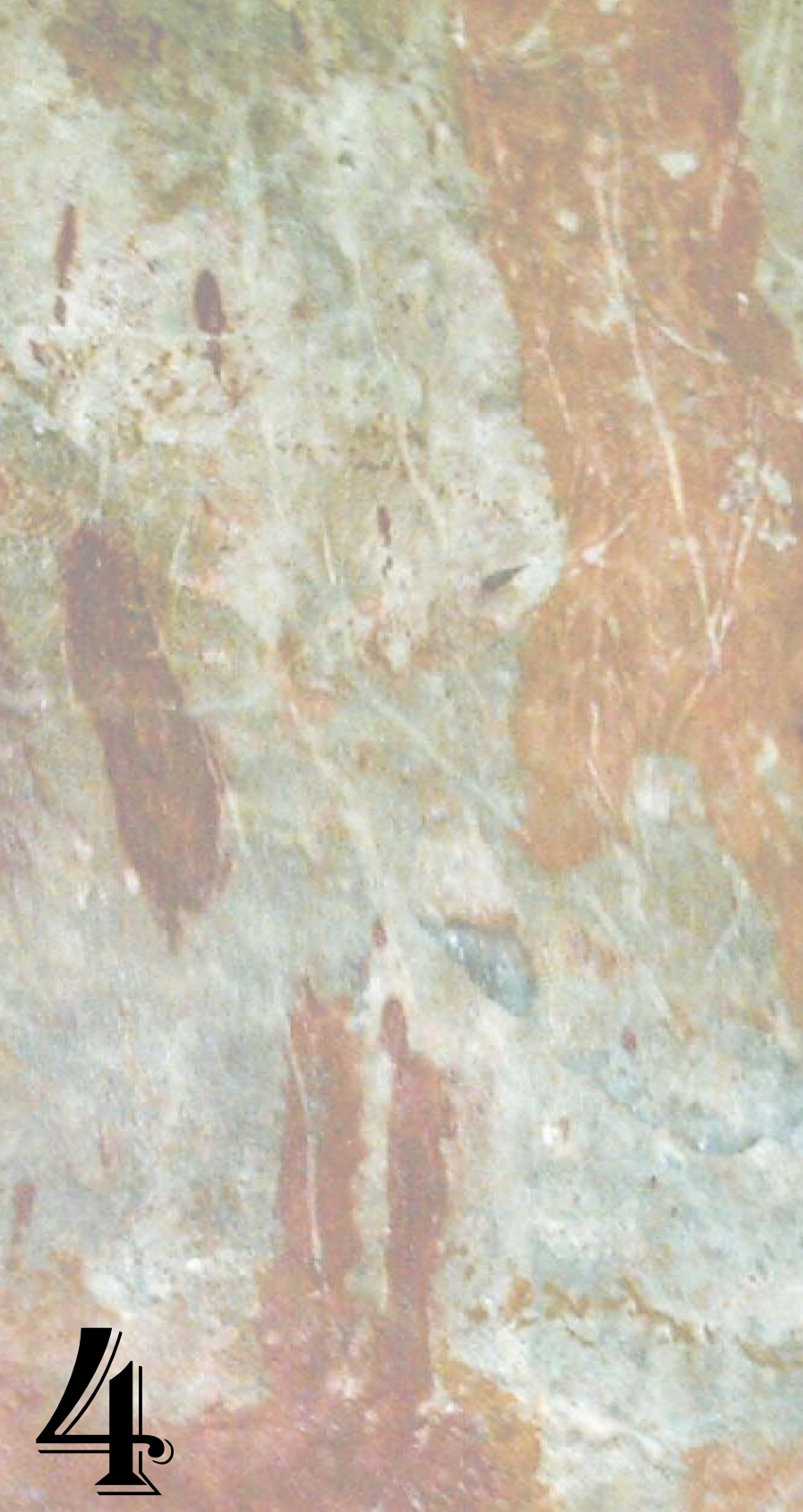

\section{GESTÃO: NOÇÕES CONCEITUAIS}

Administração é o alcance de metas organizacionais de maneira eficaz e eficiente por meio de planejamento, organização, liderança e controle dos recursos organizacionais.

Richard L. Daft 


\section{GESTÃO: NOÇÕES CONCEITUAIS}

\subsection{O QUE É ADMINISTRAÇÃO /GESTÃO}

A expressão "administração/gestão", por muito tempo foi de domínio exclusivo das empresas capitalistas e dos cursos acadêmicos que se voltavam à economia e à administração. No entanto, na atualidade têm permeado em outros campos, especialmente nas ciências humanas. Isso fica visível quando se observa que a iniciativa privada tem recorrido à filosofia, à sociologia, à psicologia, à arqueologia e a todas as áreas que, objetivamente, lhes proporcionem favorecimento econômico e/ou cumprimento de exigências de ordem legal.

A administração/gestão é entendida, segundo o Novíssimo dicionário de economia, como o "conjunto de princípios, normas e funções cuja finalidade é ordenar os fatores de produção de modo a aumentar sua eficiência"41 (SANDRONI, 2002, p.15). Richard L. Daft (2005, p. 5) afirma que a "administração é o alcance de metas organizacionais de maneira eficaz e eficiente por meio de planejamento, organização, liderança e controle dos recursos organizacionais".

O planejamento é entendido como "a função administrativa envolvida com a definição de metas para o desempenho organizacional futuro e com a decisão sobre as tarefas e o uso dos recursos necessários para alcançá-las" (DAFT, 2005, p.5). Os administradores de grandes corporações entendem que a

\footnotetext{
41 "Desde o século XIX, a administração científica tem-se desenvolvido como resposta aos problemas e desafios enfrentados pelas empresas com o avanço da Revolução Industrial. A mecanização, a automação, a produção e o consumo em massa forçaram as empresas a acrescer extraordinariamente, de forma que os padrões tradicionais de direção e controle se tornaram inadequados" ( SANDRONI, 2002, p.15).
} 
atribuição do planejamento é fator primordial para as empresas obterem sucesso e atingirem seus objetivos. Quanto à organização, o entendimento estrutura-se na seqüência do planejamento, no qual a "organização envolve a atribuição de tarefas, o agrupamento das tarefas em departamentos, e a atribuição de autoridade e alocação de recursos pela organização" (p.6). Nesse sentido, fica evidente que, para a execução do planejamento e da organização, é necessária a liderança.

A liderança, segundo Daft (2005, p. 6), consiste em "criar uma cultura compartilhada e criar valores, comunicar as metas aos funcionários por toda a organização e infundir nos funcionários o desejo de desempenhar em nível mais alto". O autor também afirma que a liderança utiliza o recurso da motivação de funcionários para obter melhores resultados em relação às metas da organização. Muitas técnicas na administração são utilizadas para constituir ou formar os líderes, mas a mais utilizada é a motivação $0^{42}$, principalmente pelos setores de recursos humanos das empresas, buscando a liderança positiva e o controle organizacional.

O controle nas organizações deve "monitorar as atividades dos funcionários, determinando se a organização está ou não no caminho em direção a suas metas e fazendo as correções quando necessárias" (DAFT, 2005, p.7). Desse ponto provêm os maiores debates referentes aos processos de administração/gestão, seja pelas grandes corporações, seja pelos críticos do capitalismo.

\footnotetext{
42 'O termo 'motivação' origina-se no campo da Psicologia, direcionado ao estudo do comportamento humano, principalmente no que diz respeito à compreensão dos motivos ou fatores que levam aos diferentes tipos de comportamento. Assim, a motivação pode ser concebida como uma energia que mobiliza e direciona um comportamento, sendo observada através do comportamento e analisada através dos fatores que lhe servem de estimulo" (ALEGRETTI; TITTONI, 1997, p.161)
} 
Segundo David Harvey (1993, p.119),

todo tipo de trabalho exige concentração, autodisciplina, familiarização com diferentes instrumentos de produção e o conhecimento das potencialidades de várias matérias-primas em termos de transformação em produtos úteis. Contudo, a produção de mercadorias em condições de trabalho assalariado põe boa parte do conhecimento, das decisões técnicas, bem como do aparelho disciplinar, fora do controle da pessoa que de fato faz o trabalho. A familiarização dos assalariados foi um processo histórico bem prolongado (e não particularmente feliz) que tem de ser renovado com a incorporação de cada nova geração de trabalhadores à força de trabalho.

O autor explana sobre a exigência de um trabalho eficiente, que vá além da força produtiva (força ou repetição), mas mostra também que é uma tarefa difícil, pois, como aos trabalhadores assalariados falta conhecimento para desenvolvê-los de maneira efetiva, deixam-se as decisões e o controle da produção a cargo do gestor, muitas vezes sobrecarregando-o, mas com o controle total.

Harvey enfatiza que o capitalismo exerce seu controle desde os tempos iniciais da industrialização, com fatores regulatórios, especialmente, porque o controle que exercem para acumular ${ }^{43}$ deve ser materializado. Portanto, regular é "uma materialização do regime de acumulação, que toma a forma de normas, hábitos, leis, redes de regulamentação etc. que garantam a unidade do processo, isto é, a consistência apropriada entre comportamentos individuais e o esquema de reprodução" (HARVEY, 1993, p.117).

$\mathrm{Na}$ estrutura de controle fabril, o relógio foi o primeiro instrumento de controle, utilizado por Frederick Winslow Taylor (1856-1915), seguido pelas idéias de Henry Ford (1863-1947), através da famosa filosofia da Administração Científica $^{44}$. Para Antônio David Cattani (1997, p. 247), o taylorismo é um "sistema

\footnotetext{
43 Harvey utiliza como suporte para suas análises os elementos da chamada Escola de Regulação a qual entende que um regime de acumulação é a "estabilização, por um longo período, da alocação do produto líquido entre consumo e acumulação; ele implica alguma correspondência entre a transformação tanto das condições de produção como das condições de reprodução de assalariados. Um sistema particular de acumulação pode existir porque seu esquema de reprodução é coerente" (HARVEY, 1993, p.117).

${ }_{44}$ Cinco princípios básicos sustentam essa administração: 1. os gerentes deveriam assumir toda a responsabilidade pela organização do trabalho, ao invés dos trabalhadores; 2 . a determinação da forma mais
} 
de organização do trabalho, especialmente industrial, baseado na separação e planejamento das funções de execução, na fragmentação e na especialização das tarefas, no controle de tempos e movimentos e na remuneração por desempenho".

Lima (2002, p. 1) considera:

O taylorismo consiste ainda na dissociação do processo de trabalho das especialidades dos trabalhadores, ou seja, o processo de trabalho deve ser independente do ofício, da tradição e do conhecimento dos trabalhadores, mas inteiramente dependente das políticas gerenciais. Taylor compreendeu e aplicou o princípio de Babbage ao separar a concepção da execução (cérebro e mãos), monopolizando o conhecimento para controlar cada fase de execução do trabalho. Ele acreditava que havia uma melhor maneira de realizar uma tarefa e a produtividade poderia ser aumentada com os operários desempenhando tarefas rotineiras e não exigindo que eles tomassem decisões.

Dentro dessa concepção, o taylorismo baseia-se numa estrutura organizada em sistemas gerenciais, proporcionando uma produção controlada, gerando, assim, uma maior rentabilidade.

O fordismo deu continuidade ao processo de controle desenvolvido por Taylor, mas com um diferencial significativo, que, segundo Sonia M.G. Larangeira (1997, p.89), "contituí-se um modelo/tipo de produção, baseado em inovações técnicas e organizacionais que se articulam tendo em vista a produção e o consumo em massa". No fordismo percebe-se uma significativa diferença entre concepção e execução do trabalho, o que permitiu ciclos rápidos na produção e, sobretudo, fragmentar o trabalho de tal forma que dispensava qualquer treinamento mais aprofundado. Associado a isso, o fordismo criou a "linha de montagem acoplada à esteira rolante, que evita 0 deslocamento dos trabalhadores e mantêm um fluxo contínuo e progressivo das peças partes, permitindo a redução dos tempos mortos e, portanto, da porosidade" (p. 90).

eficiente de realizar uma tarefa devia ser feita através de métodos científicos; 3 . os cargos devem ser providos por pessoas previamente selecionadas; 4. o trabalho seria executado eficientemente quando os trabalhadores fossem treinados; 5.a fiscalização do trabalho assegurava o cumprimento dos procedimentos e a obtenção dos resultados. (LIMA, 2002). 
De modo geral, essa concepção se mantém até os presentes dias em algumas organizações, mas, atualmente, o conceito de administração sustentado tanto no taylorismo quanto no fordismo, tem sido substituído por uma visão mais holística, ${ }^{45}$ que envolve conduzir o processo de produção econômica e social, seja das empresas privadas seja das organizações públicas. Não cabe neste momento analisar quão importante foi a evolução dessas teorias, até porque aqui não se está fazendo um estudo de administração. Todavia, é importante compreender que, a partir da década de 1970, nos países do Primeiro Mundo, e em meados da década de 1980, no Brasil, observou-se a necessidade de os capitalistas, com a concorrência mundial e a globalização, mudarem sua maneira de administrar suas empresas e organizações. Agregou-se a isso a resistência da força de trabalho em relação aos métodos repetitivos de trabalho, aos baixos salários e ao cerceamento da força de trabalho.

A nova maneira de administrar, na ótica empresarial, passou por uma reestruturação produtiva que, segundo Maria Baumgarten Corrêa (1997, p.202), "consiste em um processo que compatibiliza mudanças institucionais e organizacionais nas relações de produção e de trabalho, bem como redefinição de papéis dos Estados nacionais e das instituições financeiras, visando atender às necessidades de garantia e lucratividade". Na reestruturação produtiva desenvolvem-se várias técnicas advindas dos modelos japoneses de produção, como o Controle de Qualidade Total, Kanban, Just in Time, 5s, ou anglo-saxões, como ISO 9001, Reengenharia e outros. Além desses, constam os programas motivacionais, que promovem uma "nova relação" com o mercado ou propriamente no ambiente interno das organizações.

Para Harvey (1993, p. 140), esta nova fase que passa acontecer a partir da década de 1970, é chamada de "acumulação flexível" e é

marcada por um confronto direto com a rigidez do fordismo. Ela se apóia na flexibilidade dos processos de trabalho, dos mercados de trabalho, dos produtos e padrões de consumo. Caracteriza-se pelo surgimento de setores de produção inteiramente novos, novas maneiras

\footnotetext{
${ }^{45}$ Teoria segundo a qual o homem é um todo indivisível e que não pode ser explicado pelos seus distintos componentes (físico, psicológico ou psíquico) se considerados separadamente (HOLANDA, 2003).
} 
de fornecimento de serviços financeiros, novos mercados e, sobretudo, taxas altamente intensificadas de inovação comercial, tecnológica e organizacional. A acumulação flexível envolve rápidas mudanças dos padrões do desenvolvimento desigual, tanto entre setores como entre regiões geográficas, criando, por exemplo, um vasto movimento no emprego no chamado "setor de serviços", bem como conjuntos industriais completamente novos em regiões até então subdesenvolvidas (tais como a "Terceira Itália", Flandres, os vários vales e gargantas do silício, para não falar da vasta profusão de atividades dos países recém-industrializados). Ela também envolve um novo movimento que chamarei de "compressão do espaço-tempo" no mundo capitalista - os horizontes temporais da tomada de decisões privada e pública se estreitaram, enquanto a comunicação via satélite e a queda dos custos de transporte possibilitou cada vez mais a difusão imediata dessas decisões num espaço cada vez mais amplo e variado.

Em ambas as posições, percebe-se que há uma mudança significativa, especialmente na forma e nas estratégias de venda capitalista e nas relações que intermedeiam essas vendas. Para isso, ocorre a utilização de técnicas de caráter prático (ex. tecnologia microeletrônica) como novas formas de controle social $^{46}$. Todas as modificações ocorridas passaram a fazer parte da vida das empresas privadas ou das instituições públicas, mas também passaram a gerar um novo comportamento na sociedade. Isso, particularmente, passou a acontecer a partir da utilização e da divulgação massiva de que em todos os produtos (vendidos) ou nas próprias ações de cunho subjetivo deve-se primar pela qualidade ${ }^{47}$.

\footnotetext{
46 "O mercado de trabalho, por exemplo, passou por uma radical reestruturação. Diante da forte volatilidade do mercado, do aumento da competição e do estreitamento das margens de lucro, os patrões tiraram proveito do enfraquecimento do poder sindical e da grande quantidade de mão-deobra excedente (desempregados ou subempregados) para impor regimes e contratos de trabalho mais flexíveis. É difícil esboçar um quadro geral claro, visto que o propósito dessa flexibilidade é satisfazer as necessidades com freqüência muito específicas de cada empresa. Mesmo para os empregados regulares, sistemas como "nove dias corridos" ou jornadas de trabalho que têm em média quarenta horas semanais ao longo do ano, mas obrigam o empregado a trabalhar bem mais em períodos de pico de demanda, compensando com menos horas em períodos de redução da demanda, vêm se tornando muito mais comuns. Mais importante do que isso é a aparente redução do emprego regular em favor do crescente uso do trabalho em tempo parcial, temporário ou subcontratado". (HARVEY, 1993, p. 140).

${ }^{47}$ Segundo dicionário da (língua portuguesa) é "propriedade, atributo ou condição das coisas ou das pessoas capaz de distingui-las das outras e de lhes determinar a natureza" (HOLANDA, 2003).
} 
A qualidade total fortemente enfatizada pós - 1970, já era defendida por W. Edward Deming ${ }^{48}$, estatístico americano, na década 1940, contudo, suas preocupações estavam, principalmente, em evitar todo e qualquer desperdício. A proposta de Deming não tomou fôlego suficiente nos EUA, porém soou fortemente no Japão: "Deming e Juran, juntamente com o engenheiro japonês Ishikawa, foram os que mais influenciaram os japoneses, na formulação do modelo Total Quality Control (TQC) ao introduzirem seus princípios sobre Qualidade Total no Japão a partir dos anos 50, na tentativa de auxiliar a recuperação da indústria daquele país" (LARANGEIRA, 1997, p. 183). Objetivamente, a estratégia era utilizar processos internos nas empresas que controlassem a qualidade, partindo, então, para o mercado internacional, sustentado no princípio da qualidade, não no baixo custo.

Larangeira (1997) ratifica que

qualidade, portanto, significaria queda nos custos em razão da eliminação daquilo que, de fato, encareceria a produção, ou seja, defeitos/desperdícios e não-trabalho. Assim, a qualidade seria incorporada ao produto durante o processo de produção ao invés de ser controlada apenas ao final. Dessa forma, ela seria responsabilidade de todos os empregados e não, somente, de um departamento (p.183184).

Com essa meta estabelecida, o propósito deveria ser estendido a todos os membros da empresa e à sociedade, o que precisamente, passou a ocorrer em escala mundial a partir das décadas de 1970 e 1980. Envolver, participar e comprometer seria a tônica da busca pela qualidade total, seja na iniciativa privada, seja nos mecanismos do Estado, seja nas instituições fomentadoras do conhecimento científico (universidades, escolas técnicas e outras). Com isso, parte-se da administração pura dos métodos tradicionais da administração científica e seguindo para a gestão, como terminologia e enfoque diferenciado, voltados aos aspectos da administração e ao contexto econômico atual. Portanto, para Garay (1997, p. 101)

\footnotetext{
${ }^{48}$ Deming, como é conhecido, foi um dos fundadores da American Society for Quality Control em
} 1946. 
pode-se ter a gestão de recursos humanos, gestão de capitais, gestão de tecnologia, gestão de marketing, etc. Conforme entendido pelos administradores, de forma geral, a gestão refere-se ao processo ativo de determinação e orientação do caminho a ser seguido por uma empresa para realização de seus objetivos, compreendendo um conjunto de análises, decisões, comunicação, liderança, motivação, avaliação, controle, entre outras atividades próprias da administração.

Como se observa, a gestão, que antes era componente específico da área de administração, passou, na atualidade, a fazer parte da complexidade que envolve outros contextos do conhecimento. A gestão assume um papel interdisciplinar por ter se envolvido em áreas que contemplam mais a complexidade subjetiva das ciências humanas do que a capacidade produtiva das organizações. Nesse sentido, entende-se que a gestão passou a fazer parte da arqueologia e, especialmente, da arqueologia de projetos.

Assim, verificar-se-ão aspectos importantes sobre a gestão, como: o PDCA - P $($ Plan = Planejar $), D($ Do = Executar $), C($ Check = Verificar $), A($ Action $=$ Agir) técnica para gestão.

4.2 O PDCA - P (PLAN = PLANEJAR $), D(D O=$ EXECUTAR $), \quad C($ CHECK =
VERIFICAR $), A(A C T I O N=$ AGIR) TÉCNICA PARA GESTÃO.

Como mencionado no item anterior, percebe-se que, apesar dos esforços desenvolvidos por administradores nas décadas de 1940 e 1950 em busca da qualidade, foi somente nos últimos vinte anos que a primazia pela qualidade nos produtos e, especificamente, nos processos tem sido de significativa importância. Com um enfoque mais contemporâneo, a qualidade não é entendida meramente como a ausência de defeitos em produtos, mas, sim, como conjunto de ações eficazes e competentes em todos os momentos do processo desencadeado. "Qualidade é o conjunto de características, intrínsecas ou extrínsecas, concretas ou abstratas (...). Por ser subjetiva e pessoal, a qualidade carece de medição, é necessário estabelecer indicadores de qualidade, que meçam as dimensões da qualidade" (BUENO, 2004, p.4). 
Dentre os diversos indicadores de medição o mais utilizado é o PDCA $\mathrm{P}($ Plan $=$ Planejar $), \mathrm{D}($ Do $=$ Executar $), C($ Check $=$ Verificar $), A($ Action $=$ Agir $)$. Inicialmente, este indicador foi desenvolvido por W. Edward Deming na década de 1940, antes mesmo de propor o PDCA formulou os seguintes princípios:

\begin{tabular}{|c|c|}
\hline \multicolumn{2}{|r|}{14 princípios norteadores da qualidade } \\
\hline 1. & Constância nos propósitos \\
\hline 2. & Adoção da nova filosofia \\
\hline 3. & Introdução da qualidade desde o primeiro estágio do produto \\
\hline 4. & Fidelidade ao fornecedor \\
\hline 5. & $\begin{array}{l}\text { Melhoria constante do processo de produção ou da prestação de } \\
\text { serviço }\end{array}$ \\
\hline 6. & Treinamento no local de trabalho \\
\hline 7. & Instituição da liderança \\
\hline 8. & Eliminação do medo \\
\hline 9. & Eliminação de barreiras \\
\hline 10. & Eliminação de lemas e metas para os trabalhadores \\
\hline 11. & Eliminação da administração por objetivos \\
\hline 12. & Garantia de que o trabalhador possa se orgulhar de seu trabalho \\
\hline 13. & Instituição de programa de educação e auto-aprimoramento \\
\hline 14. & Engajamento em todo conjunto da empresa. \\
\hline
\end{tabular}

Figura 9: 14 princípios norteadores da qualidade

Para Deming, a lógica desses princípios deveria, inicialmente, perfazer a vida interna nas fábricas ou organizações produtivas e, posteriormente, ser estendida a todas as ações constantes na vida em sociedade. "O método Deming 
não se preocupou só com a qualidade de produtos e serviços, mas também com a qualidade de vida das pessoas e, com sua proposta do saber profundo, foi o primeiro a se preocupar com o lado humano da qualidade" (BUENO, 2004, p.16).

Segundo Deming, mudar de forma profunda os relacionamentos e os gerenciamentos, seja nas empresas, seja na sociedade, assumiria um caráter efetivamente revolucionário. Solucionar os problemas de gerenciamento e envolver as pessoas nos processos proporcionaria a resolução de mais de $90 \%$ dos problemas inerentes às organizações.

Com esse intuito, Deming propôs o método PDCA - P (Plan = Planejar), $\mathrm{D}($ Do = Executar $), \quad C($ Check = Verificar $), A($ Action $=$ Agir $)$, que tem sido uma poderosa ferramenta universal de gestão da qualidade para todo tipo de organização. "O PDCA é um método de controle. Método é, por definição, um caminho para se atingir a meta" (BUENO, 2004, p.16). Nesse sentido, o PDCA é assim entendido:

\begin{tabular}{|c|c|}
\hline \multicolumn{2}{|r|}{ Estrutura do PDCA } \\
\hline P (Plan = Planejar) & $\begin{array}{l}\text { Definir o que se quer. Planejar o que será feito. } \\
\text { Estabelecer metas. Definir os métodos que permitirão } \\
\text { atingir as metas propostas. }\end{array}$ \\
\hline D (Do = Executar) & $\begin{array}{l}\text { Tomar iniciativa, educar, treinar, implementar, executar } \\
\text { o planejado conforme as metas e métodos definidos. }\end{array}$ \\
\hline $\mathrm{C}($ Check $=$ Verificar $)$ & $\begin{array}{l}\text { Verificar os resultados que se está obtendo. Verificar } \\
\text { continuamente os trabalhos para ver se estão sendo } \\
\text { executados conforme planejados. }\end{array}$ \\
\hline A (Action = Agir) & $\begin{array}{l}\text { Fazer correções de rotas se for necessário, tomar } \\
\text { ações corretivas ou de melhoria, caso tenha sido } \\
\text { constatada na fase anterior a necessidade de corrigir } \\
\text { ou melhorar processos. }\end{array}$ \\
\hline
\end{tabular}

Fonte: www.indg.com.br

Figura 10: Estrutura do PDCA 
O Planejamento (Plan) está intimamente ligado às metas e aos objetivos a serem alcançados pelas empresas, grupos ou organizações. "A meta deve ser clara, quantificável, realista, envolvente e contendo um desafio para estímulo e crescimento das pessoas. A falta de uma definição clara da meta é uma das principais razões do insucesso de muitos projetos" (BUENO, 2004, p.16). Definir as estratégias e agregá-las a um método que possibilite atingir as metas é o fundamento de um planejamento bem feito. Contudo, segundo Bueno (2004, p.16), "um bom Plano de Ação deve conter os chamados: o que fazer, quem deve fazer, quando fazer, onde fazer, como fazer, porque fazer e, finalmente, quanto investir. Todos esses elementos são importantes, mas os seguintes merecem cuidados especiais: o responsável (quem), o prazo (quando) e o motivo (porque)"

$\mathrm{Na}$ Execução (Do) devem-se tomar os devidos cuidados para que as metas não sejam abandonadas pela simples existência de variáveis mensuráveis ou imensuráveis na fase do planejamento. Nesse sentido, Bueno (2004, p. 17) recomenda cuidado com os seguintes aspectos:

Educação $^{49}$. É o trabalho de explicação da meta e do plano, de forma que todos os envolvidos entendam e concordem com o que se está propondo ou foi decidido. Nesta fase procura-se atingir o intelecto e as emoções das pessoas, para que não apenas saibam, mas se entusiasmem com o projeto. Treinamento. É o desenvolvimento das habilidades necessárias para que o projeto possa ser levado com êxito ao final. Treinar significa ensinar como fazer. $O$ treinamento sem ser precedido de educação não passa de adestramento e inútil para o trabalho dentro do conceito de $T Q C^{50}$. Execução. Somente após a educação e treinamento deve-se executar o plano, tomando cuidado para que seja feito de acordo com o que foi realmente planejado. Coleta de dados. Enquanto se executa, devem-se coletar dados, para viabilizar a etapa seguinte.

Muitas organizações, em especial dos países recém-industrializados, tomam o treinamento como imposição de rotinas, transformando-as de maneira significativa, ao que Bueno chama de "adestramento", situação que leva as

\footnotetext{
${ }^{49}$ Grifo meu.

${ }^{50}$ Total Quality Control (TQC).
} 
organizações a abandonar ou distorcer significativamente seus objetivos em relação à qualidade e ao processo planejado.

$\mathrm{Na}$ Verificação (Check) defronta-se corriqueiramente com a avaliação do processo, situação comumente desagradável, mas necessária, porque expressa e manifesta o papel de cada personagem ou componente com as metas e os objetivos. A avaliação nada mais é do que determinar a valia ou o valor de uma ação para a qual a organização ou o grupo se propôs nas metas e objetivos. "Durante e após a execução, deve-se comparar os dados obtidos com a meta planejada, para se saber se está indo a direção certa ou se a meta foi atingida" (BUENO, 2004, p. 17).

$\mathrm{Na}$ Ação corretiva (Action) encontram-se duas formas distintas: padronização ou contramedidas. A padronização é feita quando a meta é atingida. Padronizar é transformar o plano que deu certo na nova maneira de fazer as coisas. Ação corretiva consiste em se fazer uma análise para descobrir em que etapa se cometeu um erro (meta, plano, educação, treinamento, execução) e tomar as medidas necessárias para atingir a meta (BUENO, 2004).

$\mathrm{Na}$ ação corretiva presenciam-se reações adversas, pois, quando se trata de elementos envolvendo custos financeiros, as reações são as mais diversas possíveis, as quais vão desde a indignação, quando as ações acontecem e dão errado até a exuberância de transformar um produto em "modelo exemplar" de toda organização. Quando se trata de projetos de cunho mais subjetivo, muitas ações corretivas são ignoradas e, muitas vezes, negligenciadas ao passado: "errou-se, deixa-se morto no passado", parte-se para uma ação / projeto novo. Particularmente, as verificações e as ações corretivas estão intimamente ligadas, seja para elucidar o transcorrido no desenvolvimento do projeto, seja para abandonar a situação existente. 
No Brasil, o PDCA é defendido e trabalhado por Vicente Falconi Campos $^{51}$ (2005, p.12), o qual declara que o PDCA está diretamente vinculado à Teoria Geral de Sistemas:

todo sistema é constituído de partes interligadas com uma função específica. O conceito de "partes interligadas" faz com que o significado de "sistema" seja similar ao de "processo". A função específica de um Sistema de Gestão é produzir resultados, atingir metas ou resolver problemas, o que é tudo a mesma coisa (gerenciar é resolver problemas!). Portanto, o Sistema de Gestão é constituído de partes interligadas com a função específica de produzir resultados para a organização.

O PDCA, para Campos, é desenvolvido para produzir resultados na organização em que será ou está sendo aplicado. Contudo, não se devem esperar resultados a curto prazo, porque o fator educativo e de absorção dos participantes é demorado e gradativo, pois é rara a organização que possui um quadro de colaboradores homogêneo e que tenha a facilidade de assimilar $o$ processo rapidamente. Nesse aspecto, Campos (2005, p. 12) salienta:

O tempo é fato fundamental no aprendizado das pessoas. A única condição é que se tenham resultados abundantes a cada passo para que as pessoas se animem a dar os passos seguintes. O consultor é um professor e a consultoria é um processo de aprendizado. A nossa experiência mostra, de forma bem clara, que o mercado rejeita o consultor que fica "implantando" coisas e não produz resultados. A meta é a força motriz e os resultados são o prêmio maior do aprendizado. $O$ mercado só compra resultados.

Os resultados que interessam às organizações ou ao mercado devem considerar o conhecimento ${ }^{52}$ e as informações ${ }^{53}$ circulantes como um diferencial

\footnotetext{
${ }^{51}$ Vicente Falconi Campos é do Instituto de Desenvolvimento Gerencial (INDG), sediado no estado de Minas Gerais, e é considerado o guru do PDCA e dos Programas de Qualidade Total no Brasil. ${ }^{52}$ Para Harvey (1993), o "acesso ao conhecimento científico e técnico sempre teve importância na luta competitiva; mas, também aqui, podemos ver uma renovação de interesse e de ênfase, já que, num mundo de rápidas mudanças de gostos e necessidades e de sistemas de produção flexíveis (em oposição ao mundo relativamente estável do fordismo padronizado), o conhecimento da última técnica, do mais novo produto, da mais recente descoberta científica, implica a possibilidade de alcançar uma importante vantagem competitiva. O próprio saber se torna uma mercadoria-chave, a ser produzida e vendida a quem pagar mais, sob condições que são elas mesmas cada vez mais organizadas em bases competitivas. Universidades e institutos de pesquisa competem ferozmente por pessoal, bem como pela honra de patentear primeiro novas descobertas científicas" (p.151).
} 
de crescimento interno e como uma "grande mercadoria". Dessa forma, a ligação com as estratégias é fundamental, isto é, o conhecimento ou a informação não aflora por si só; é primordial que seja desenvolvido o estímulo, caso contrário, o conhecimento e as informações dificilmente serão considerados um diferencial competitivo. Valorizar o ser humano numa organização e dar-lhe as condições materiais necessárias não é suficiente se a gestão não atribuir um modelo de conduta que norteie o dia-a-dia da organização; em caso contrário, determinados procedimentos e certas ferramentas organizacionais poderão ser prejudiciais à organização. Para Sveiby (1998, p.152), “uma estratégia orientada para o conhecimento gera lucros cada vez maiores, basicamente a partir de ativos intangíveis, ativos que convertem receitas invisíveis gerada por um grande número de atividades em receitas tangíveis".

O Ciclo de Gerenciamento (método) para a realidade brasileira desenvolvido por Campos (abaixo) não destoa da proposta enfatizada por Deming.

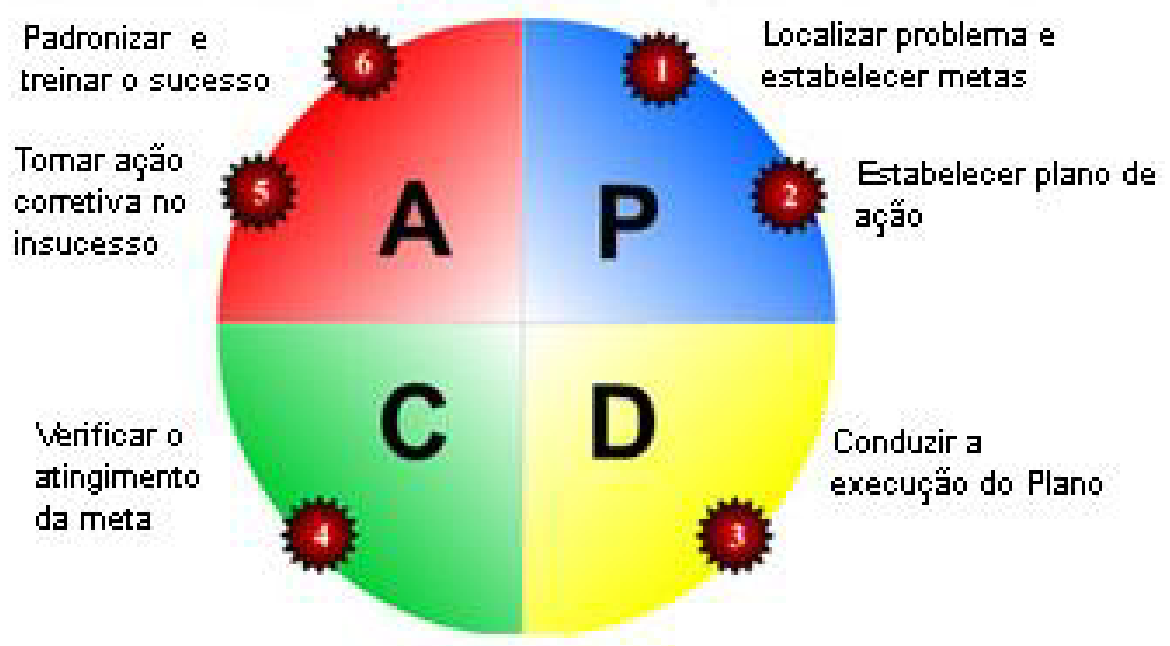

Fonte: Instituto de Desenvolvimento Gerencial

Figura 11:O ciclo do gerenciamento PDCA

53 Segundo Harvey (1993), "as informações precisas e atualizadas são agora uma mercadoria muito valorizada. O acesso à informação, bem como o seu controle, aliados a uma forte capacidade de análise instantânea de dados, tornaram-se essenciais à coordenação centralizada de interesses corporativos descentralizados" (p.151). 
Entretanto, é importante enfatizar que, tanto para Deming como para Campos, o PDCA pressupõe conhecer e identificar as dificuldades e estabelecer metas; estabelecer um plano de ação; garantir a execução do plano e verificar, periodicamente, os resultados e a implementação do plano (DEMARCO, 2005).

O PDCA não se expande de forma mecanicista ou de maneira tediosa e imutável; é primordial que seja liderado, administrado de forma efetiva. A liderança fará com que o PDCA busque o comprometimento. Não que o líder fará tudo sozinho, mas, sim, orientará, conduzirá. "Sem uma boa liderança pouca coisa acontece. Uma boa liderança muitas vezes até compensa parcialmente a inexistência de um preparo técnico ou gerencial" (CAMPOS, 2005, p.12).

No esquema seguinte, Campos demonstra qual é a ligação que a liderança deve estabelecer com o processo nas organizações.

\section{LIDERANÇA}

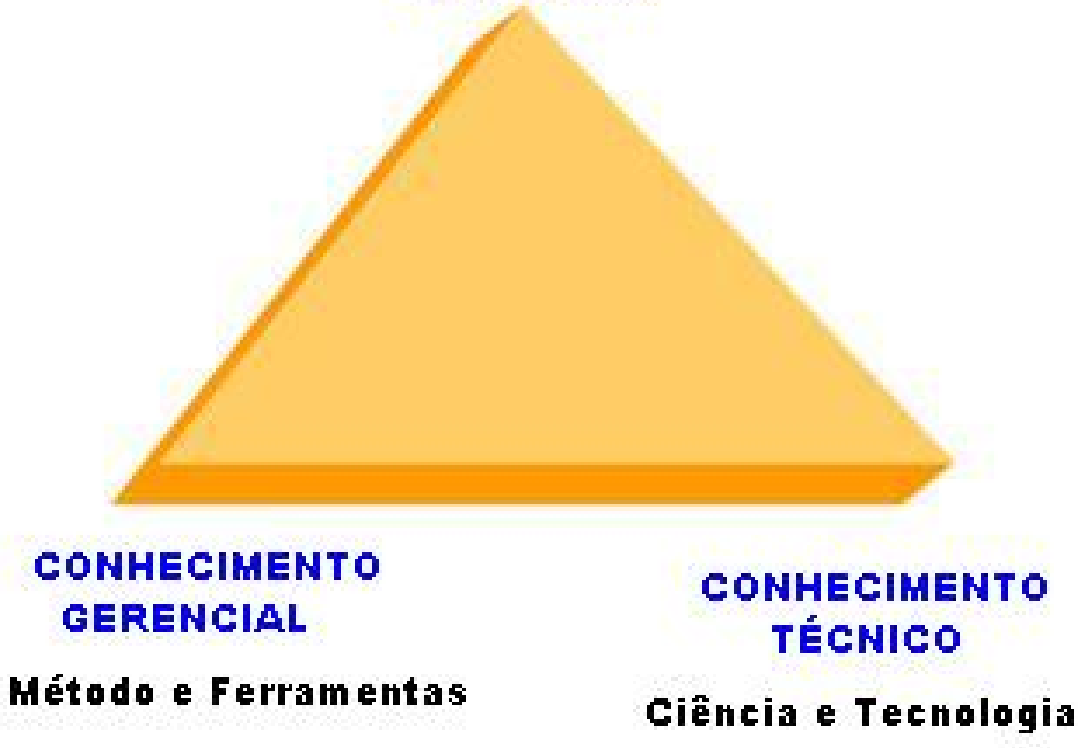

Fonte: Instituto de Desenvolvimento Gerencial

Figura 12: O esquema da liderança no PDCA 
Esse esquema demonstra que a liderança, quando se apropria do conhecimento técnico e gerencial, cria fatores primordiais para as organizações se tornarem viáveis.

Os gestores internos ou consultores externos das organizações que acreditam no PDCA devem utilizar dois produtos, segundo Campos (2005):

Produtos Gerenciais - São produtos que combinam diretamente o método (PDCA) e algumas ferramentas que viabilizem melhor, para uma situação específica, o tratamento das informações. Nesse caso as ferramentas devem ser inseridas dentro do método, pois este último é o que viabiliza, de fato, o atingimento e manutenção dos resultados. Produto Ferramental - São produtos que levam para a empresa o domínio de certas ferramentas para que estas possam ser utilizadas dentro de seu próprio processo gerencial. É o caso da Engenharia de Sistemas para a Manutenção, da Análise de Confiabilidade e de Valor para os processos empresariais etc.

Nesse sentido, analisar e medir os processos é muito relevante para a sua manutenção e melhoria, contemplando, inclusive, o planejamento, a padronização e a documentação destes. São papéis que a liderança das organizações, quando bem preparada, consegue desempenhar a fim de atingir as metas e os resultados desejados. "A consciência do Sistema de Gestão, aliada ao domínio dos vários produtos de gestão existentes, fornece ainda ao consultor a percepção de sua função de orientar a empresa na construção desse sistema. Essa concepção sistêmica e, portanto, participativa do gerenciamento mostra que somente em equipe é possível dar consultoria empresarial" (CAMPOS, 2005).

Com o PDCA, a figura do chefe com caráter impositivo, que se sustentava na hierarquia, na distância, no temor e no conflito, deve ser substituída pela imagem do líder que conduz pela legitimidade, pelo respeito, reconhecimento e admiração, que a liderança deve despertar. "Associado a esse, está o princípio que propõe a eliminação do medo, no sentido de favorecer a liberdade de expressão de idéias, de crítica, de sugestões e de exposição de dúvidas, imprescindível para criar o clima de colaboração e de cooperação desejado" (LARANGEIRA, 1997, p.184). A valorização que o líder deve dar à equipe 
caracteriza-o como apto a influenciar o comportamento positivo para os demais membros da organização. Para Deming, "uma organização não apenas precisa de gente boa, mas de gente que se aprimore sempre..." e ainda, "as pessoas querem mais do que dinheiro, quer oportunidades crescentes de contribuir com algo à sociedade (...)" (LARANGEIRA, 1997, p.185).

Os programas de qualidade total utilizados na atualidade e, por conseqüência, o PDCA, ao contrário do que fazia o fordismo, procuram considerar os participantes das organizações como o maior patrimônio. Para Larangeira (1997, p. 186),

\begin{abstract}
essa proposta de gestão apóia-se numa transformação cultural que atingiria a empresa como um todo, incluindo a esfera gerencial e a alta gerência. Nesse sentido, apregoa-se a necessidade de redução dos níveis hierárquicos e de descentralização e de autogerenciamento de departamentos/setores/áreas/agências,a delegação de tarefas e o compartilhamento de responsabilidade, a circulação de informações (o negócio, a missão, os objetivos e os planos da empresa deveriam ser amplamente conhecidos e divulgados) e a transparência nas decisões. Essas recomendações configurariam o estilo de gestão participativa, fundamentando-se, principalmente, na eliminação de barreiras entre chefia e subordinados e na tomada de decisão por consenso, traduzindo uma concordância geral, $\mathrm{o}$ que garantiria $\mathrm{O}$ comprometimento do grupo como um todo. No que se refere aos trabalhadores, destaca-se a atitude de comprometimento com os objetivos da empresa, juntamente com a adesão a uma ética do trabalho, de tal forma que ele se transforme em preocupação central na vida do indivíduo.
\end{abstract}

O PDCA deve ser interpretado com uma visão dinâmica, pois, se aplicado de maneira contínua, levará ao aprimoramento dos processos, das pessoas e das tarefas, estabelecendo uma diferença positiva nos projetos e na gestão das organizações. Assim, desenvolver o PDCA é gerar, de forma sistêmica, o aperfeiçoamento passo a passo, degrau a degrau, usando as estratégias de planejar, fazer, verificar, agir corretivamente, modificar o planejamento em função da ação corretiva tomada, refazer, se necessário, tornar a verificar e a corrigir o plano. Girar o PDCA em forma de espiral levará ao refinamento do método utilizado, pois comprometer as pessoas de toda a estrutura significa fazer de fato o que está traçado na gestão. Desse modo, constitui o processo completo de Avaliar, Planejar, Fazer, Verificar e Aperfeiçoar. 
Nesse aspecto, o PDCA oferece aos seus seguidores uma visão abrangente de administrar e gerenciar e tornando a metodologia mais organizada, oportunizando a participação de todos; consequentemente, haverá um maior comprometimento e uma significativa diminuição de erros. Esse meio de administrar não distancia o gestor do executor, proporcionando uma efetiva cumplicidade nos atos realizados. Parafraseando Morin (2003), na obra "A Cabeça Bem-feita", a complexidade dos elementos só se concretiza se o todo observar as partes e as partes o todo, motivando a uma cabeça bem-feita.

Com base nos aspectos abordados, pretende-se, de modo audacioso, applicar esses elementos aos projetos do meio ambiente, mais especificamente, nesta tese, aos de arqueologia. 


\section{ARQUEOLOGIA PREVENTIVA : EXEMPLO DE GESTÃO}

O cidadão comum precisa compreender sua importância no processo sociocultural no qual está inserido, almejando uma transformação positiva no seu relacionamento com o patrimônio cultural.

José Luis de Morais 


\section{ARQUEOLOGIA PREVENTIVA: EXEMPLO DE GESTÃO}

O novo desafio proposto na atualidade, como já se observou por meio dos diferentes olhares da arqueologia, recebe um novo impulso e um novo desafio, de entender essa ciência como garantia para as próximas gerações. É nesse sentido que este capítulo procura analisar a arqueologia preventiva.

Mas o que é e como se apresenta esse novo conceito? Como se pode entendê-lo como uma nova forma de gestão nos projetos de arqueologia? Talvez a resposta, numa primeira impressão, seja inerente à própria conceituação do termo 'prevenção', que no dicionário da língua portuguesa representa o "ato ou efeito de prevenir (-se). Disposição ou preparo antecipado e preventivo. Modo de ver antecipado; premeditação, precaução, cautela" (HOLANDA, 2003).

Tal conceituação, entretanto, quando vinculada à arqueologia, assume proporções diferenciadas, especialmente, porque desafia os seus seguidores a encará-la como uma proposta de gestão, não meramente como um princípio ou uma norma a ser seguida.

José Luis de Morais (In: SILVA, 1998, p.351), o maior defensor da arqueologia preventiva, afirma:

[...] a arqueologia preventiva própria do licenciamento ambiental passa por esta reflexão, especialmente quando se pensa na gestão de qualidade $e$ não na pura e simples quantidade de arqueoinformação. Outros princípios basilares comparecem vivamente: a interdisciplinaridade e a transdisciplinaridade que sustentam os preceitos teóricos e metodológicos não apenas nos estudos de arqueologia preventiva são uma aplicação holística per se, pois refletem a intenção de construir pontes sobre as fronteiras disciplinares e a tradição, acolhendo o princípio da totalidade.

O saber local, especialmente no ambiente de campo, deverá ser fortemente considerado. $O$ paradigma holístico está vinculado à concepção sistêmica, entendida como a maneira de ver os fenômenos ou 
eventos de um todo coordenados entre si, de modo que funcionem como uma estrutura organizada. Por outro lado, o paradigma ecossistêmico também subsidiará a investigação arqueológica no licenciamento ambiental, acompanhando a abordagem sistêmica do mundo, no qual todos os elementos, inclusive as sociedades humanas, interagem em uma imensa rede de relações, tal como uma World Wide web. Assim, natureza e sociedade fundem-se em uma totalidade organizada. Visão ecossistêmica e holística se integra e interage na medida em que tratam de relações e de totalidade

No conceito proposto por Morais, observa-se que a busca pela interface é primordial para a arqueologia manter-se atual e, sobretudo, relevante nos meios acadêmicos e na sociedade civil organizada ${ }^{54}$. Na proposta de trabalho coordenado verificam-se dois termos que são costumeiramente utilizados nas áreas acadêmicas e fora delas, que são a interdisciplinaridade e a transdisciplinaridade, os quais exigem condutas gestionárias e uma abertura para características inovadoras. Outros dois conceitos firmados na ciência administrativa são as posturas holística e sistêmica ${ }^{55}$, que, por sua vez, comportam uma visão integradora, mas exigente em se tratando de operacionalidade. Por isso, Morais propõe que a arqueologia preventiva navegue por conceitos e definições como expresso nos quadros a seguir:

${ }^{54}$ Entende-se sociedade civil organizada como a composição de instituições que representam ações corporativas e representativas no meio social.

${ }^{55}$ Referente à visão orgânica, lógica de um sistema. 


\section{Áreas de influência na arqueologia preventiva}

Área de

influência

expandida - AIE

Área diretamente afetada - ADA
É constituída pelo município (ou o conjunto de municípios) onde se pretende instalar o empreendimento projetado. Enquanto ente federativo de terceiro grau, cada município é competente para propor e executar políticas públicas na área do patrimônio cultural, no lastro dos dispositivos legais supralocais. Individualmente, o município é uma unidade geográfica de gestão patrimonial - UGGP.

É constituída pela fração de terreno circunscrita pela linha poligonal desenhada no respectivo projeto, onde se instalará o empreendimento. O planejamento estratégico define que a ADA (literalmente constituída pela planta de uso e ocupação do empreendimento) é potencialmente uma unidade geográfica de manejo patrimonial - UGMP, compartimento abrangido pela arqueoinformação regional e privilegiado na avaliação arqueológica. 


\begin{tabular}{|c|c|}
\hline $\begin{array}{c}\text { Área de } \\
\text { Influência Direta } \\
\text { - AID }\end{array}$ & $\begin{array}{l}\text { É constituída pela faixa de terreno de dimensão variável } \\
\text { que circunscreve a ADA. Em situações rotineiras, a AID } \\
\text { contém a ADA e é contida pela AIE. Porém,ao contrário } \\
\text { delas, cujos limites praticamente se autodefinem (planta } \\
\text { do empreendimento, no primeiro caso, e divisas } \\
\text { municipais, no segundo), a AID tem delimitação } \\
\text { convencional adaptada a cada situação, em } \\
\text { considerando o grau de significância do patrimônio } \\
\text { arqueológico detectado (ou o potencial arqueológico } \\
\text { implícito). Sua demarcação tem dois propósitos } \\
\text { essenciais: conectar o manejo executado na ADA com a } \\
\text { gestão implementada da AIE; constituir um cinturão } \\
\text { envoltório que funcione como faixa de amortecimento de } \\
\text { impactos ao patrimônio arqueológico externo à ADA. }\end{array}$ \\
\hline
\end{tabular}

Adaptado dos textos de José Luiz de Morais

Figura 13: Áreas de influência na arqueologia preventiva 


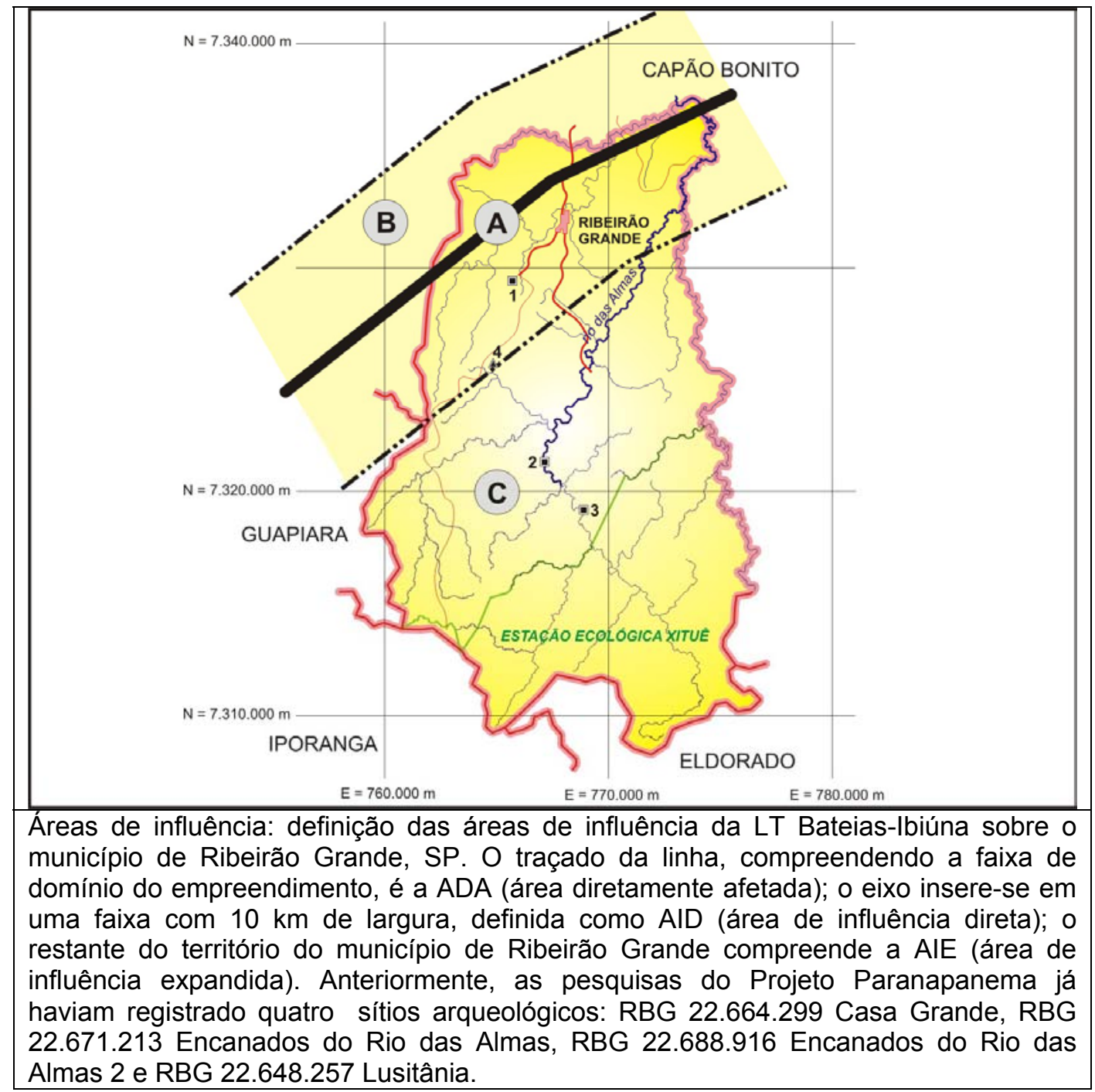

Figura 14 - Mapa com áreas de influência 


\section{Fundamentação conceitual para arqueologia preventiva}

Registro

Arqueológico
É a referência genérica aos objetos, artefatos, estruturas e construções produzidas pelas sociedades do passado, inseridas em determinado contexto. Quando soterrado, o registro arqueológico inclui a matriz pedológica ou sedimentar que contextualiza objetos, assinaturas latentes, etc. Trata-se de conceito amplo que independe de sua posterior classificação como sítio, ocorrência ou geoindicador arqueológico. Abrange as assinaturas arqueológicas evidentes (p. ex., um conjunto funerário) e as assinaturas arqueológicas latentes ( $p$. ex., as assinaturas físico-químicas que eventualmente corroboram estruturas funerárias praticamente invisíveis). Incluem certos arranjos paisagísticos, como aqueles decorrentes do manejo das florestas por agricultores indígenas, bem como os elementos do meio físico-biótico de interesse para a arqueologia (p.ex., os diques clásticos ou as cascalheiras que serviram de fonte de matéria-prima para as indústrias líticas). A anotação formal de sítios e ocorrências arqueológicas é procedimento obrigatório em qualquer circunstância e será feita por meio do preenchimento de formulário próprio ${ }^{56}$. Os geoindicadores arqueológicos serão anotados de acordo com o grau de significância, que inclui, dentre outros, sua precisa correlação com sítios e ocorrências arqueológicas.

${ }^{56}$ Preferencialmente a ficha do CNSA - Cadastro Nacional de Sítios Arqueológicos, sistema operado pelo IPHAN, parcialmente disponível na página do órgão federal (www.iphan.gov.br). 


\begin{tabular}{|c|l|l|}
\hline \multirow{2}{*}{\begin{tabular}{|l} 
O conjunto de registros coordenados pela presença de um \\
ou mais geoindicadores arqueológicos constitui um sistema \\
local de registros arqueológicos. Exemplo: os sítios, \\
ocorrências e locais de interesse arqueológico \\
relacionados com os agricultores pré-coloniais do entorno \\
de corredeiras podem se articular pela presença de alguns \\
Registro
\end{tabular}} & $\begin{array}{l}\text { geoindicadores principais: os barreiros (utilizados como } \\
\text { fontes de matérias-primas para a produção de cerâmica), } \\
\text { compondo significativa reserva para atividades minerárias } \\
\text { de argila; as cascalheiras de litologia diversificada } \\
\text { (utilizadas como fontes de matérias-primas para a } \\
\text { produção de artefatos líticos), compondo significativa } \\
\text { reserva para atividades minerárias de pedra; e, finalmente, } \\
\text { os acidentes do leito do rio, que compõem um conjunto de } \\
\text { corredeiras e vaus, ambientes propício à apanha sazonal } \\
\text { de peixes migratórios e transposição do rio5r. }\end{array}$ \\
\hline Sistema & $\begin{array}{l}\text { Pogional de } \\
\text { A coordenação entre registros arqueológicos, inferida pelas } \\
\text { possíveis relações espaciais, socioeconômicas e culturais, } \\
\text { considerando sua proximidade, contemporaneidade, } \\
\text { similaridade ou complementaridade, indica um sistema } \\
\text { regional de povoamento. O conceito de sistema regional de } \\
\text { povoamento tem sua melhor sustentação na geografia, } \\
\text { pois se refere à dispersão das populações pelo ecúmeno } \\
\text { terrestre e à conseqüente produção paisagens, com a } \\
\text { construção de cenários que se sucedem. Na sua esteira } \\
\text { são admitidos dois macros-sistemas indígenas pré- } \\
\text { coloniais: caçadores-coletores e agricultores. No primeiro } \\
\text { caso, pode ser incluído o sistema umbu, correlacionável à }\end{array}$ \\
\hline \hline
\end{tabular}

${ }^{57}$ Os sítios, ocorrências e geoindicadores arqueológicos da área do antigo salto Simão, no rio Paranapanema, município de Piraju, resgatados no programa de salvamento arqueológico da UHE Piraju, constituem um sistema local de registros arqueológicos integrados por todas as variáveis citadas. 


\begin{tabular}{|c|c|}
\hline & $\begin{array}{l}\text { tradição arqueológica homônima, que gerou cenários de } \\
\text { adaptação às condições ambientais de transição pelos } \\
\text { planaltos do sul do Brasil. No segundo caso, os guaranis } \\
\text { constituem um sistema que produziu recortes paisagísticos } \\
\text { com forte indentidade regional, organizando-se em sistema } \\
\text { regional de povoamento com design plenamente adaptada } \\
\text { às condições ambientais da transição entre as zonas } \\
\text { tropical e temperada do quadrante sudeste do } \\
\text { subcontinente. No período pós-conquista ibérica, as frentes } \\
\text { pioneiras da sociedade nacional geraram sistemas e } \\
\text { cenários específicos, ditados por novas ordens } \\
\text { econômicas e sociais. }\end{array}$ \\
\hline \multirow[t]{2}{*}{$\begin{array}{c}\text { Sítio } \\
\text { Arqueológico }\end{array}$} & $\begin{array}{l}\text { Termo unitário e fundamental na classificação dos registros } \\
\text { arqueológicos. Corresponde à menor unidade do espaço } \\
\text { passível de investigação, dotada de objetos (e outras } \\
\text { assinaturas latentes) intencionalmente produzidos ou } \\
\text { rearranjados, que testemunham comportamentos das } \\
\text { sociedades do passado. Um sítio só pode ser definido } \\
\text { como tal após a sua verificação enquanto registro } \\
\text { arqueológico. Sítio de referência é aquele que, por suas } \\
\text { características topomorfológicas, estratigráficas e crono- } \\
\text { culturais, serve de apoio para as interpretações regionais e } \\
\text { respectivas inserções }{ }^{58} \text {. }\end{array}$ \\
\hline & $\begin{array}{l}\text { É cada município enquanto ente federativo dotado de } \\
\text { competência para propor e executar políticas públicas } \\
\text { locais de valorização do patrimônio cultural e ambiental, } \\
\text { inclusive o arqueológico. De direito, no Estado federal } \\
\text { brasileiro compete aos Municípios gerir tudo o que é de }\end{array}$ \\
\hline
\end{tabular}

58 O sítio arqueológico PRJ 22.627.385 Camargo, com seqüência estratigráfica formada por remanescentes dos sistemas regionais umbu e guarani (quatro estratos datados), é um sítio de referência para os registros arqueológicos multicomponenciais. 


\begin{tabular}{|c|c|}
\hline $\begin{array}{c}\text { Unidade de } \\
\text { Gestão } \\
\text { Patrimonial - } \\
\text { UGGP }\end{array}$ & $\begin{array}{l}\text { interesse local, suplementando a legislação federal e } \\
\text { estadual, no que couber }{ }^{59} \text {. No caso do patrimônio } \\
\text { arqueológico, cabe-lhe a ele proteger os sítios } \\
\text { arqueológicos em parceria com a União e com o respectivo } \\
\text { Estado Federado, implementando programas, projetos e } \\
\text { ações de educação patrimonial e uso social dos sítios e } \\
\text { locais de interesse para a arqueologia, consideradas as } \\
\text { normas federais em vigor }{ }^{60} \text {. }\end{array}$ \\
\hline $\begin{array}{c}\text { Unidade } \\
\text { Geográfica de } \\
\text { Manejo } \\
\text { Patrimonial - } \\
\text { UGMP }\end{array}$ & $\begin{array}{l}\text { Corresponde à fração de terreno onde são executados os } \\
\text { procedimentos de reconhecimento, levantamento, } \\
\text { prospecção e escavação arqueológica. Geralmente é } \\
\text { constituída por um módulo arqueológico balizado por } \\
\text { coordenadas do sistema UTM (como mostrado na figura } \\
\text { 3). Cada sítio detectado é delimitado por um polígono } \\
\text { convencional, assumido como perímetro restrito, local onde } \\
\text { se concentram os procedimentos de prospecção e } \\
\text { escavação do registro arqueológico. Envolvendo este } \\
\text { perímetro, poderá ser definida uma faixa de segurança } \\
\text { externa }{ }^{61} \text { varrida pelas ações de reconhecimento e } \\
\text { levantamento arqueológico, reconhecida como perímetro } \\
\text { expandido. Opcionalmente, a UGMP pode focar uma } \\
\text { microbacia hidrográfica. }\end{array}$ \\
\hline
\end{tabular}

Figura 15 - Fundamentação conceitual para arqueologia preventiva

Quando o entendimento das Áreas de Influência na Arqueologia Preventiva estiver claro para os pesquisadores, existirá uma aproximação da

${ }_{60}^{59}$ Constituição Federal, art. 30, I.

${ }^{60}$ Constituição Federal, art. 30, IX.

${ }^{61}$ Adicionalmente caracterizada como zona de amortecimento de impactos, considerando que um sítio arqueológico pode assumir, de fato, algumas prerrogativas de unidade de conservação. A Resolução Conama 013, de 6 de dezembro de 1990, estabelece normas referentes ao entorno das unidades de conservação. 
base conceitual da ciência arqueológica, especialmente pelo que está expresso no quadro de Fundamentação Conceitual para Arqueologia Preventiva.

José Luiz de Morais, antes de mencionar o que é um sítio arqueológico, fundamenta todo o entorno e, precisamente, a idéia de tempo e espaço que envolveu as sociedades pretéritas, passando pelos registros arqueológicos, pelos sistemas locais e regionais de povoamento. Posteriormente a isso, fundamenta seu entendimento muito próximo à via clássica, de que um sítio arqueológico é "à menor unidade do espaço passível de investigação, dotada de objetos (e outras assinaturas latentes) intencionalmente produzidos ou rearranjados, que testemunham comportamentos das sociedades do passado" (MORAIS, 2006, 207).

Nesse sentido, aproxima o conceito e o entendimento de sitio arqueológico da ciência geográfica quando propõe Unidade de Gestão Patrimonial (UGGP) e Unidade Geográfica de Manejo Patrimonial (UGMP). Precisamente, não só pela definição da geografia, mas também quando entende que o município, como ente federativo, é responsável pela preservação e gestão dos bens culturais e arqueológicos. Sabe-se que, na prática, há um distanciamento da teoria com os exercícios reais, em face das grandes dificuldades por que passam os Municípios brasileiros, sejam financeiras, sejam de cunho político íntegro e comprometido com a preservação arqueológica, além de que, geralmente, a ignorância se faz presente, pois seus dirigentes não sabem ou não entendem o significado do bem arqueológico.

No quadro abaixo pode-se observar que Morais explica os conceitos e definições da arqueologia preventiva, com o objetivo de tornar esta ciência mais interativa com o social, eliminando a visão restrita à acadêmica. 


\section{Conceitos e definições da arqueologia preventiva (Planejar)}

\begin{tabular}{|c|c|}
\hline Arqueoinformação & $\begin{array}{l}\text { Referência genérica a quaisquer informações } \\
\text { relativas à arqueologia e ao patrimônio arqueológico } \\
\text { no sentido lato, quer sejam dados arqueológicos } \\
\text { propriamente ditos, ou dados de interesse } \\
\text { arqueológico provenientes das disciplinas afins da } \\
\text { arqueologia, gerenciáveis em sistema de informação } \\
\text { geográfica (SIG aplicado à arqueologia). }\end{array}$ \\
\hline $\begin{array}{l}\text { Evidência e } \\
\text { Indícios } \\
\text { arqueológicos }\end{array}$ & $\begin{array}{l}\text { Evidência é uma assinatura arqueológica direta, } \\
\text { concreta, evidente; tem sentido de certeza manifesta. } \\
\text { O indício é uma assinatura arqueológica indireta. }\end{array}$ \\
\hline $\begin{array}{l}\text { Geoindicadores } \\
\text { arqueológicos }\end{array}$ & $\begin{array}{l}\text { São elementos do meio físico-biótico dotados de } \\
\text { alguma expressão locacional para os sistemas } \\
\text { regionais de povoamento, indicando locais de } \\
\text { povoamento antigo. Exemplos: cascalheiras de } \\
\text { litologia diversificada, diques de arenito silicificado, } \\
\text { pavimentos detríticos (matérias-primas de boa fratura } \\
\text { conchoidal para lascamento) etc. }\end{array}$ \\
\hline Geoprocessamento & $\begin{array}{l}\text { É o ato de estabelecer a ligação entre a informação } \\
\text { literal [banco de dados] ou gráfica [vetor ou bitmap] e } \\
\text { a sua posição específica no globo terrestre, por meio } \\
\text { de coordenadas. O georreferenciamento mais } \\
\text { comum e obrigatório no processo de investigação } \\
\text { arqueológica é a amarração dos registros } \\
\text { arqueológicos no sistema de posicionamento global, }\end{array}$ \\
\hline
\end{tabular}




\begin{tabular}{|c|l|}
\hline \multicolumn{1}{|c|}{\begin{tabular}{|l|} 
por meio de um receptor GPS. O \\
georreferenciamento se insere no âmbito das \\
geotecnologias, grupo de tecnologias referentes à \\
informação geograficamente referenciada. Dentre \\
elas destacam-se o sistema de posicionamento \\
global, o geoprocessamento, a fotogrametria, o \\
sensoriamento aéreo ou orbital, a topologia e a \\
geodésia. O uso das geotecnologias disponíveis, \\
especialmente o sistema de posicionamento global, é \\
imprescindível na investigação arqueológica.
\end{tabular}} \\
\hline Intervenções & $\begin{array}{l}\text { São procedimentos técnicos respaldados em } \\
\text { plataformas metodológicas e conceituais que } \\
\text { permitem a leitura dos objetos [na acepção mais } \\
\text { plena] como documentos arqueológicos. As. As } \\
\text { intervenções produzem ações aparentemente } \\
\text { díspares: ora desmontam o registro arqueológico, } \\
\text { ora o consolidam. As intervenções no solo são na } \\
\text { cota negativa [sondagens, cortes, trincheiras, } \\
\text { decapagens] ou na cota zero [coletas de superfície]. } \\
\text { As intervenções nas edificações ocorrem na cota } \\
\text { zero [piso atual], na cota negativa, quando se } \\
\text { relacionam com as fundações, ou, mais } \\
\text { freqüentemente, na cota positiva quando se } \\
\text { relacionam com as paredes e a cobertura } \\
\text { [sondagens de parede, decapagens cromáticas, etc]. }\end{array}$ \\
\hline \begin{tabular}{l|l} 
nas edificações \\
alguns ambientes sedimentares podem conter \\
evidências de ocupações humanas do passado, \\
compondo com elas algum tipo de registro \\
estatuto de matriz arqueológica, proporcionando o
\end{tabular} \\
\hline
\end{tabular}




\begin{tabular}{|c|c|}
\hline Matriz arqueológica & $\begin{array}{l}\text { contexto que mantém as assinaturas físicas e } \\
\text { químicas de natureza antrópica. A ausência dessa } \\
\text { matriz, todavia, não desqualifica um registro } \\
\text { arqueológico como tal, embora limite as } \\
\text { investigações. De fato, materiais arqueológicos } \\
\text { diretamente depositados sobre substratos rochosos } \\
\text { melhor se caracterizam como agregados de objetos } \\
\text { potencialmente sujeitos a contínua redeposição, } \\
\text { posto que desprovidos da matriz sedimentar } \\
\text { arqueológica protetora. } \\
\text { O padrão de assentamento desenhado na maior } \\
\text { parte do território brasileiro demonstra que, em seus } \\
\text { respectivos contextos primários, a maior parte dos } \\
\text { remanescentes arqueológicos de caçadores- } \\
\text { coletores foi capeada por sedimentos aluviais [sítios } \\
\text { de terraço], assim como os registros de agricultores } \\
\text { indígenas o foram por sedimentos coluviais [sítios } \\
\text { colinares]. Solos residuais, resultantes de } \\
\text { decomposição de rocha in situ, mantêm objetos } \\
\text { arqueológicos em superfície. }\end{array}$ \\
\hline $\begin{array}{l}\text { Modelo locacional } \\
\text { e modelo empírico }\end{array}$ & $\begin{array}{l}\text { Um modelo locacional foi formulado a partir da } \\
\text { construção de um modelo empírico resultante da } \\
\text { práxis da disciplina na bacia do rio Paranapanema: } \\
\text { assinaturas arqueológicas [objetos, evidências } \\
\text { latentes, etc.] constantemente presentes em alguns } \\
\text { compartimentos da paisagem sugeriam escolhas } \\
\text { bem-sucedidas, determinadas por condições } \\
\text { ambientais favoráveis. O modelo empírico se } \\
\text { construiu pela detecção, consolidação e } \\
\text { mapeamento dessas assinaturas em seus } \\
\text { respectivos suportes paisagísticos. A partir daí, os }\end{array}$ \\
\hline
\end{tabular}


suportes foram assumidos como geoindicadores arqueológicos. O modelo locacional, de caráter preditivo, baseou-se no mapeamento [por meio da interpretação de sensores orbitais e suborbitais] dos suportes assumidos como geoindicadores arqueológicos, convergindo para a previsão dos compartimentos da paisagem potencialmente aptos a apresentar assinaturas dos povos indígenas précoloniais. Cascalheiras de litologia diversificada, corredeiras, afloramentos de rochas de boa fratura conchoidal, barreiros, trechos de manejo agroflorestal, terraços marginais, vaus de rios são, dentre outros, geoindicadores arqueológicos.

Módulo

arqueológico
Porção de terreno balizada pelas coordenadas planas de referência do sistema Mercátor [coordenadas UTM] ou pelos divisores de uma microbacia hidrográfica. É a menor unidade geográfica de organização espacial da investigação arqueológica, assumindo, neste caso, o estatuto de termo unitário e fundamental. Módulos arqueológicos podem ser definidos a posteriori, em função da presença de um sistema local de sítios arqueológicos.

Exemplo: uma seqüência de degraus no leito de um rio identifica um espaço geográfico que encerra um sistema local de sítios arqueológicos, resultante da conjunção favorável de alguns fatores tidos como geoindicadores arqueológicos.

É um tipo de macro-assinatura dos povos précoloniais, corrente nos sítios de agricultores.

Conhecido por mancha preta, é um corpo sedimentar 


\begin{tabular}{|c|l|}
\hline Núcleo de solo & $\begin{array}{l}\text { remanescente de antigos so-los de habitação e seu } \\
\text { cinturão envoltório, depósitos de lixo, áreas de } \\
\text { cocção de alimentos, etc. Surge como manchas } \\
\text { ovaladas de solo enegrecido pelo elevado teor de } \\
\text { materiais biogênicos coletados, processados e } \\
\text { descartados pelas comunidades pré-coloniais, rico } \\
\text { em evidências arqueológicas, principalmente } \\
\text { fragmentos de cerâmica e estruturas de combustão. }\end{array}$ \\
\hline Ontropoenico caso do sistema regional guarani, são, com \\
\hline Ocorrência & $\begin{array}{l}\text { freqüência, os remanescentes da tapy-iguassu, a } \\
\text { casa-grande e seu entorno. }\end{array}$ \\
\hline arqueológica & $\begin{array}{l}\text { Objeto único ou quantidade ínfima de objetos } \\
\text { aparentemente isolados ou desconexos encontrados } \\
\text { em determinado local [uma ponta de flecha, um } \\
\text { fragmento de cerâmica, um pequeno trecho de } \\
\text { alicerce, etc.]. A ocorrência arqueológica poderá } \\
\text { ganhar estatuto de sítio a partir da posterior detecção } \\
\text { de evidências adicionais que permitam esta nova } \\
\text { classificação. }\end{array}$ \\
\hline Padrão de & $\begin{array}{l}\text { A distribuição dos registros arqueológicos em } \\
\text { determinada área geográfica resulta das relações } \\
\text { das comunidades do passado com o meio ambiente } \\
\text { e das relaçães entre elas próprias, no contexto } \\
\text { ambiental. Estratégias de subsistência, estruturas } \\
\text { políticas e sociais e densidade da população foram } \\
\text { alguns dos fatores que influenciaram a distribuição } \\
\text { do povoamento, desenhando os padrões de } \\
\text { povoamento. }\end{array}$ \\
\hline assento
\end{tabular}




\begin{tabular}{|c|l|}
\hline Patrimônio & $\begin{array}{l}\text { Se o patrimônio cultural é a representação da } \\
\text { memória, o patrimônio arqueológico é a sua } \\
\text { materialização. Em outras palavras, trata-se do } \\
\text { conjunto de expressões materiais da cultura } \\
\text { referente aos povos indígenas pré-coloniais e aos } \\
\text { diversos segmentos da sociedade nacional [inclusive } \\
\text { as situações de contato interétnico]. Potencialmente } \\
\text { incorporáveis à memória local, regional ou nacional, } \\
\text { o patrimônio arqueológico compõe parte da herança } \\
\text { cultural legada pelas gerações do passado às } \\
\text { gerações futuras. } \\
\text { Na perspectiva da arqueologia da paisagem, o } \\
\text { patrimônio arqueológico inclui alguns segmentos da } \\
\text { natureza onde se percebe uma artificialização } \\
\text { progressiva do meio, gerando paisagens notáveis, de } \\
\text { relevante interesse arqueológico. }\end{array}$ \\
\hline Perfil de solo & $\begin{array}{l}\text { Corte no terreno que permite o exame e a descrição } \\
\text { dos solos no seu ambiente natural. Demonstra a } \\
\text { sucessão de horizontes pedogenéticos e antrópicos } \\
\text { contidos em uma seção vertical, a partir da superfície } \\
\text { do terreno [cota zero]. No registro arqueológico de } \\
\text { agricultores indígenas, a práxis tem demonstrado } \\
\text { que são suficientes os perfis com um metro de } \\
\text { profundidade [o comum é mapear a matriz } \\
\text { arqueológica até a profundidade de 50 cm, em } \\
\text { ambiente coluvial; nos solos residuais, as evidências } \\
\text { costumam estar na superfície]. Pedon é a unidade } \\
\text { tridimensional mínima para descrição e coleta de } \\
\text { amostras de solo. O conceito de Pedon é mais } \\
\text { abrangente que o de perfil, pela sua } \\
\text { tridimensionalidade. A evidenciação, leitura, análise }\end{array}$ \\
\hline
\end{tabular}




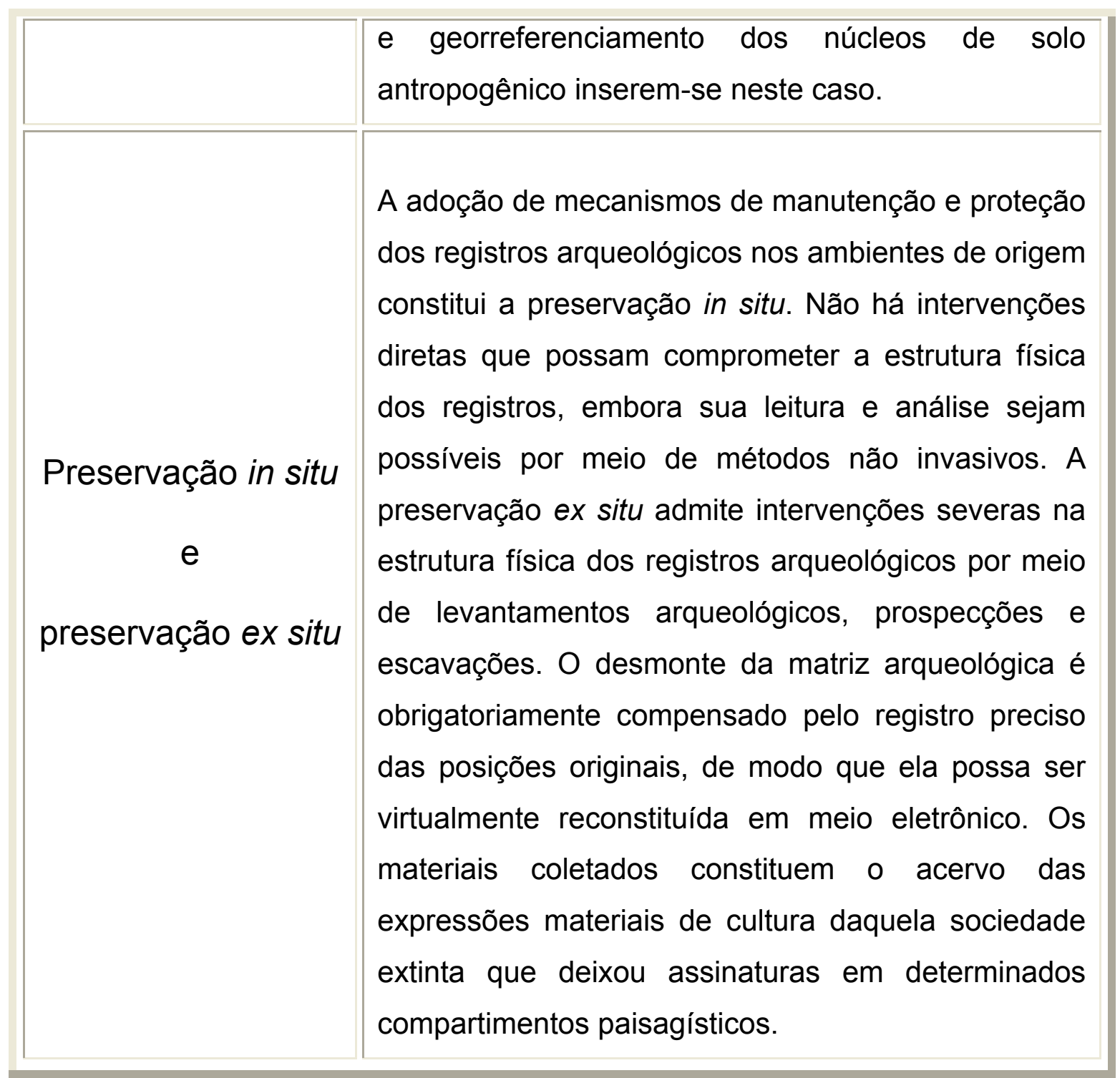

Adaptado dos textos de José Luiz de Morais

Figura 16 - Conceitos e definições da arqueologia preventiva (Planejar) 


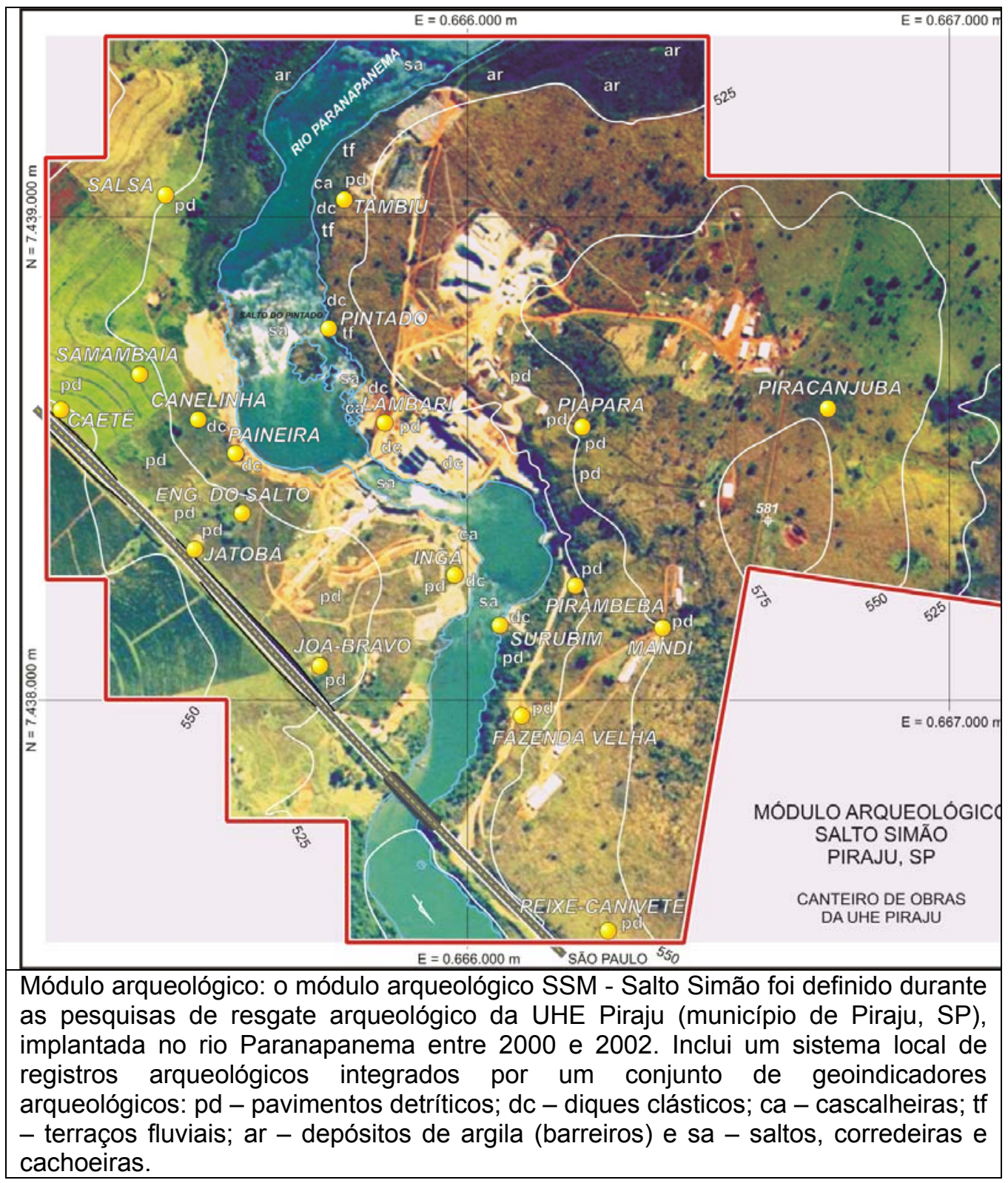

Figura 17 - Módulo arqueológico

Nos conceitos e definições referendados não se percebem posturas e dogmas elencados, mas se observa que o exposto vai, de forma direta ou indireta, buscar na gestão o embasamento do proposto e o conceito de gestão já mencionado em capítulo anterior, expressando o "conjunto de princípios, normas e funções cuja finalidade é ordenar os fatores de produção de modo a aumentar sua eficiência" (SANDRONI, 2002, p.15) Administrar é alcançar as metas organizacionais de maneira eficaz e eficiente por meio de planejamento, organização, liderança e controle dos recursos organizacionais" (DAFT, 2005, p. 5). 
O planejamento, como primeiro ponto da gestão, é entendido como "a função administrativa envolvida com a definição de metas para o desempenho organizacional futuro e com a decisão sobre as tarefas e o uso dos recursos necessários para alcançá-las" (DAFT, 2005, p.5). Morais, ao propor os conceitos especificados, compreende claramente em todos os conceitos colocados essa necessidade de clareza na base conceitual e, precisamente, como condicionante fundamental da arqueologia preventiva.

Verifica-se que Morais não concebe na sua base conceitual dogmas ou qualquer situação fechada e acabada; procura, sim, orientar pela necessidade e pela lógica da persuasão. Um exemplo claro é quando propõe a Matriz arqueológica, mas afirma: "A ausência dessa matriz, todavia, não desqualifica um registro arqueológico como tal, embora limite as investigações". Neste viés é que se constata que os conceitos estão abertos, mas, necessariamente, deverão ser conduzidos por um ente portador da capacidade de liderança, presumindo que um bom arqueólogo é um líder com capacidade condutora para minimamente organizar um planejamento e, sobretudo, atender às demandas existentes de forma interdisciplinar e transdisciplinar.

Morais, na lógica dos conceitos e formulações, fundamenta e propõe conceitos para a execução dos trabalhos de arqueologia preventiva. É claro que essa separação entre o primeiro e o segundo quadro conceitual é feita para fins de compressão didática e para se entender melhor o desenvolvimento da gestão nos projetos de arqueologia. 


\section{Conceitos e definições da arqueologia preventiva (Executar)}

\section{Procedimentos em campo}

Reconhecimento

É o rastreamento da paisagem para a avaliação preliminar das potencialidades arqueológicas. O reconhecimento transita entre grandes e pequenas extensões, de acordo com o foco da abordagem, classificando-se como reconhecimento de paisagem e reconhecimento de terreno, respectivamente. Sua operacionalização se dá por meio do planejamento e execução de reconhecimento de terreno (vez por outra, este tipo de reconhecimento é entendido como "visual"), por meio de rota georreferenciada, com vértices marcados por pontos avaliados como estratégicos em termos de observação e coleta de dados. Não são executadas intervenções na matriz sedimentar ou nos registros arqueológicos; não são efetuadas coletas. O reconhecimento da paisagem abrange extensões maiores, incluindo vários compartimentos ambientais [escalas macro à intermediária, área de influência expandida]. Vale-se da exploração prévia de acervos documentais [inventários preexistentes] e de interpretações temáticas a partir de mapas e sensoriamento remoto [imagens suborbitais e orbitais]. Permite a compreensão dos recortes de paisagem, com a definição dos compartimentos significativos para a compreensão dos sistemas regionais de povoamento, posto que sejam encaminhadas observações acerca do ambiente físico-biótico regional e dos desenhos territoriais. O georreferenciamento é feito na grade do sistema UTM, preferencialmente na escala 1:50.000. O reconhecimento 
de terreno abrange extensões menores, restringindo-se a um ou dois compartimentos topomorfológicos [escalas intermediária a micro, área diretamente afetada]. Vale-se de observações espontâneas e induzidas. A eficácia do reconhecimento de terreno reside na otimização dos recursos de análise da geoarqueologia. $\mathrm{O}$ georreferenciamento é feito na grade do sistema UTM, preferencialmente em escalas maiores que 1:2.000.

É o de rastreamento de registros arqueológicos para a avaliação preliminar da região ou do local, em termos de patrimônio arqueológico. O levantamento transita entre extensões maiores ou menores, de acordo com o foco da abordagem [escalas intermediária a micro, unidade geográfica de manejo patrimonial, área de influência direta]. Sua operacionalização se dá por meio do planejamento e execução de sondagens na matriz sedimentar, em pontos avaliados como estratégicos, marcados por geoindicadores arqueológicos [eventualmente, pode ser fixada uma malha de sondagem casuística ou ritmada, em intervalos regulares]. Este procedimento também é reconhecido como levantamento prospectivo. Detectados registros arqueológicos, são feitas coletas amostrais comprobatórias semi-controladas. O levantamento arqueológico aponta para a prospecção.

A intervenção de pequeno porte no registro arqueológico abrange coletas controladas, retificação de barrancos e ravinamentos, diversos tipos de sondagem nos registros arqueológicos e decapagens em superfícies restritas. A prospecção proporciona o detalhamento ambiental da matriz arqueológica e coletas amostrais sistemáticas, 


\begin{tabular}{|l|l|}
\hline Prospecção & $\begin{array}{l}\text { permitindo a avaliação da extensão dos registros } \\
\text { arqueológicos em subsuperfície. A amarração é feita na } \\
\text { grade do sistema UTM, em escala micro [superiores a } \\
1: 1.000], \text { em planimetria ou modelagens digitais de terreno } \\
\text { especialmente geradas para essa finalidade [unidade } \\
\text { geográfica de manejo patrimonial, área diretamente } \\
\text { afetada]. }\end{array}$ \\
\hline \multirow{5}{*}{$\begin{array}{l}\text { Escavação } \\
\text { revela a distribuição tridimensional das estruturas na matriz } \\
\text { original, permitindo o encaminhamento de análises das } \\
\text { relações intra-sítio [núcleos de solo antropogênico são } \\
\text { dissecados por decapagens; estratos arqueológicos são } \\
\text { evidenciados em micro estratigrafia]. A escavação apóia-se } \\
\text { em métodos complementares: superfícies amplas [limpeza } \\
\text { do terreno, amarração planialtimétrica georreferenciada, } \\
\text { abertura de trincheiras e cortes] e etnográficas [decapagem } \\
\text { por níveis naturais amarrada em microtopografia } \\
\text { georreferenciada]. A escavação permite a elaboração de } \\
\text { plantas e modelagens digitais de terreno em escalas } \\
\text { maiores que 1:1.000 [microescala]. Os registros } \\
\text { arqueológicos escavados inserem-se em unidades } \\
\text { geográficas de manejo patrimonial. }\end{array}$} \\
\hline
\end{tabular}

Figura 18 - Conceitos e definições da arqueologia preventiva (Executar) 


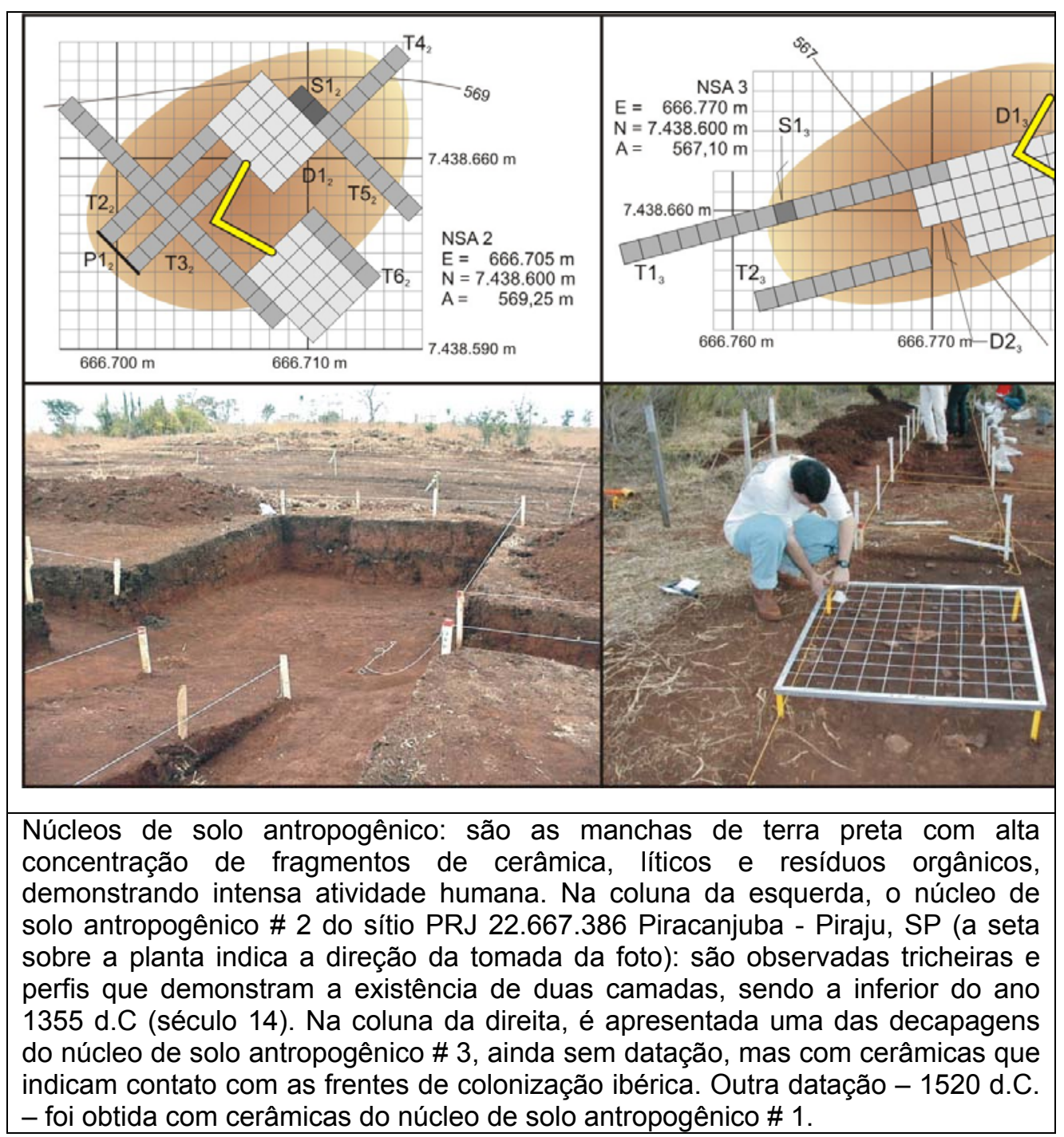

Figura 19 - Núcleos de solo antropogênico

$\mathrm{Na}$ ótica de manter os aspectos da interdisciplinaridade e da transdisciplinaridade como linha da arqueologia preventiva propondo a arqueologia da paisagem, Morais (2005, p.361) entende que,

A arqueologia da paisagem é a linha de pesquisa escolhida para subsidiar o estudo de arqueologia preventiva e esta centrada em vários segmentos da interface arqueologia/geografia, a arqueologia da paisagem objetiva o estudo dos processos de artificialização do meio e dos cenários produzidos, na perspectiva dos sistemas regionais de povoamento. De fato, seu foco central é a reconstrução dos cenários das ocupações humanas por meio do estudo da dispersão das populações pelas regiões do planeta, gerando sistemas regionais de povoamento e produzindo paisagens de identidade marcante. 
A pergunta que se pode fazer é: Mas como tratar a arqueologia sem paisagem?, No entanto, Morais (2005) entende que, "no caso da arqueologia da paisagem, o termo é preferencialmente visto sob a ótica da sociedade, ou seja, a paisagem é construída e continuamente reconstruída pela sociedade em mudança" $(2006,2009)$ De forma indireta, percebe-se que o vínculo com a geografia é entendido como processo de forma macro o autor resume:

\begin{abstract}
Resumindo, a paisagem, resultado do processo de artificialização do ambiente, é objeto da arqueologia da paisagem, linha de pesquisa que estuda a regularidade, o arranjo e a distribuição das transformações do meio ambiente em uma área geográfica definida. $O$ processo de artificialização do ambiente resulta na sucessão de cenários plenamente articulados, reforçando a complexidade do conceito de paisagem construída. De fato, a paisagem analisada pelo arqueólogo não é apenas o ecossistema mas, sim, o lugar pleno de assinaturas antrópicas que se sucedem no tempo. Pela forma e evolução da paisagem construída, procura-se chegar aos seus autores (361).
\end{abstract}

O reconhecimento dos cenários da arqueologia na ótica do macro e do microuniverso coloca a arqueologia não como ciência meramente voltada à análise de "caquinhos", mas a arqueologia preventiva/paisagem busca "fundamentar-se nas bases teóricas e conceituais das disciplinas de origem, a arqueologia da paisagem converge seus esforços para duas dimensões: a matriz ambiental [tópico relacionado com o meio físico-biótico] e o ambiente construído [tópico relacionado com o meio sócio-econômico e cultural]" (MORAIS, 2006). O autor afirma ainda que a arqueologia da paisagem se "configura como uma estratégia de investigação para o estudo dos processos sociais em sua dimensão espacial, reconstruindo e interpretando a evolução da paisagem arqueológica e os padrões de assentamento a partir das expressões materiais da cultura" .

Se a estratégia é a arte de aplicar os meios disponíveis com vista à consecução de objetivos específicos, nota-se que a arqueologia da paisagem irá proporcionar uma visão mais ampla dos aspectos arqueológicos e será propulsora na quebra do paradigma tradicional da arqueologia, isto é, "a arqueologia da paisagem trata da inclusão da práxis arqueológica em coordenadas espaciais" (MORAIS, 2005). Ora, só se pode incluir algo quando este não está incluso. Nesse sentido, Morais questiona o porquê de os empreendimentos modernos 
(LTs, hidroelétricas, PCHs, etc.) estarem impactando o meio ambiente e o patrimônio arqueológico. Cabe aos defensores desses se agilizarem e partirem para a inclusão da práxis arqueológica, porém, não é qualquer prática, pois a "qualidade de georreferenciar procedimentos, cenários ou sistemas regionais de povoamento confere à arqueologia da paisagem um estatuto ímpar: a competência para tratar de assuntos relacionados com o design da arqueologia em sua dimensão de planejamento, gestão e manejo do patrimônio arqueológico" (MORAIS, 2005).

Quando Morais propõe uma práxis arqueológica, entende que a ciência arqueológica deve buscar caminhos de extroversão (que se expande) e, para isso, utilizar a arqueologia preventiva como educação patrimonial e inclusão social. Para o autor não se necessitaria vincular a educação patrimonial aos aspectos legais da Portaria 230/02 em razão de que os aspectos educacionais deveriam ser abrangidos pela Lei Federal 9.795, de 27 de abril de 1999, especialmente porque, em seus principais objetivos, incisos I e III, salienta que o (I) "o desenvolvimento de uma compreensão integrada do meio ambiente em suas múltiplas e complexas relações, envolvendo aspectos ecológicos, psicológicos, legais, políticos, sociais, econômicos, científicos, culturais e éticos "; e (III) "o estímulo e o fortalecimento de uma consciência crítica sobre a problemática ambiental e social".

$\mathrm{Na}$ realidade, os objetivos estavam postos, mas sem uma objetividade prática e, precisamente, sem contemplar a arqueologia. Morais salienta que, em muitos "programas de educação ambiental, quando compareciam como medida mitigatória (ou compensatória) no licenciamento ambiental, teimavam em se restringir ao meio-biótico)"(MORAIS, 2005, p. 364 -365). Com isso, abriu-se espaço para o IPHAN destacar a educação patrimonial na Portaria 230/02.

Morais utiliza o conceito de educação patrimonial elaborado por Lourdes P. Horta (1999, p25): "processo permanente e sistemático de trabalho 
educacional centrado no patrimônio cultural, como fonte primária de conhecimento e enriquecimento individual e coletivo"62.

Percebe-se que, quando Morais (2006, p.212) remete à educação patrimonial como elemento da arqueologia preventiva, não a desmembra em seu métodos e procedimentos, até porque, o ato de educar assume proporções diferenciadas em cada contexto social. Contudo, afirma que,

o cidadão comum precisa compreender sua importância no processo sociocultural no qual está inserido, almejando uma transformação positiva no seu relacionamento com o patrimônio cultural. Trabalhar com o acervo arqueológico por meio da educação patrimonial é interagir com a memória local, talvez interferindo em lugares de memória onde a comunidade se reconhece, memoriza imagens concretas e apreensões visuais.

A devolução proposta por Morais pode ser entendida tanto para a linha nos processos educacionais formais como não formais, com a possibilidade de as atividades se tornarem um verdadeiro instrumento de alfabetização cultural. "Por meio deste instrumento, espera-se induzir transformações na maneira de se tratar a cultura, tanto da parte dos profissionais (acadêmicos ou não), como das comunidades envolvidas no processo" (MORAIS, 2006, p.212)

${ }^{62}$ Citando o Guia Básico de Educação Patrimonial, de Maria de Lourdes P. Horta, Evelina Grumberg e Adriane Q. Monteiro, co-edição IPHAN/Museu Imperial, 1999, p. 6. Este pensar de Katianne Bruhns (bem como o que segue adiante) é veiculado no projeto de educação patrimonial e inclusão social do estudo de arqueologia preventiva da linha de transmissão Bateias-lbiúna, desenvolvido pelo Museu de Arqueologia e Etnologia da Universidade de São Paulo, sob a coordenação de Morais. 


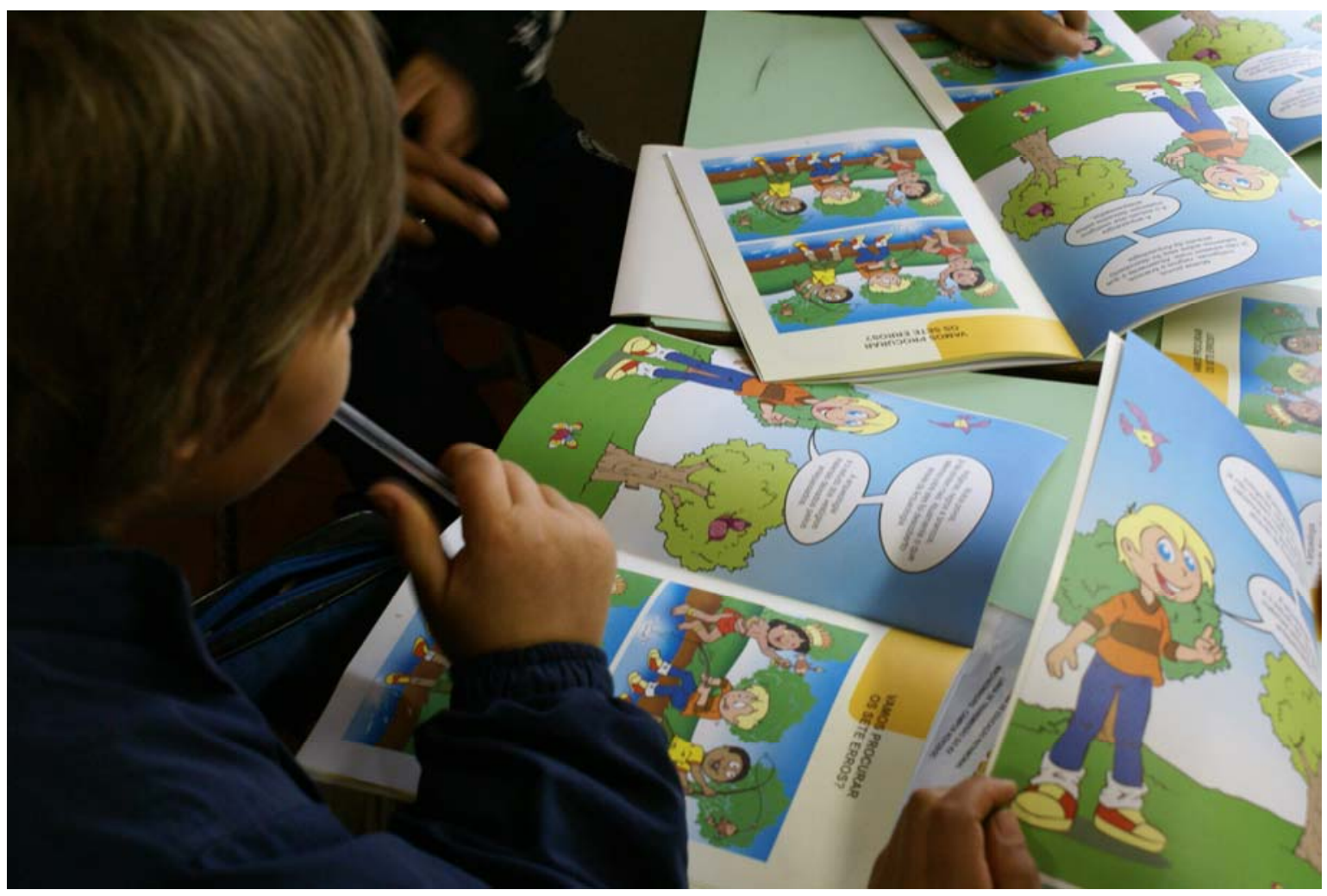

Figura 20 - Educação patrimonial: leitura

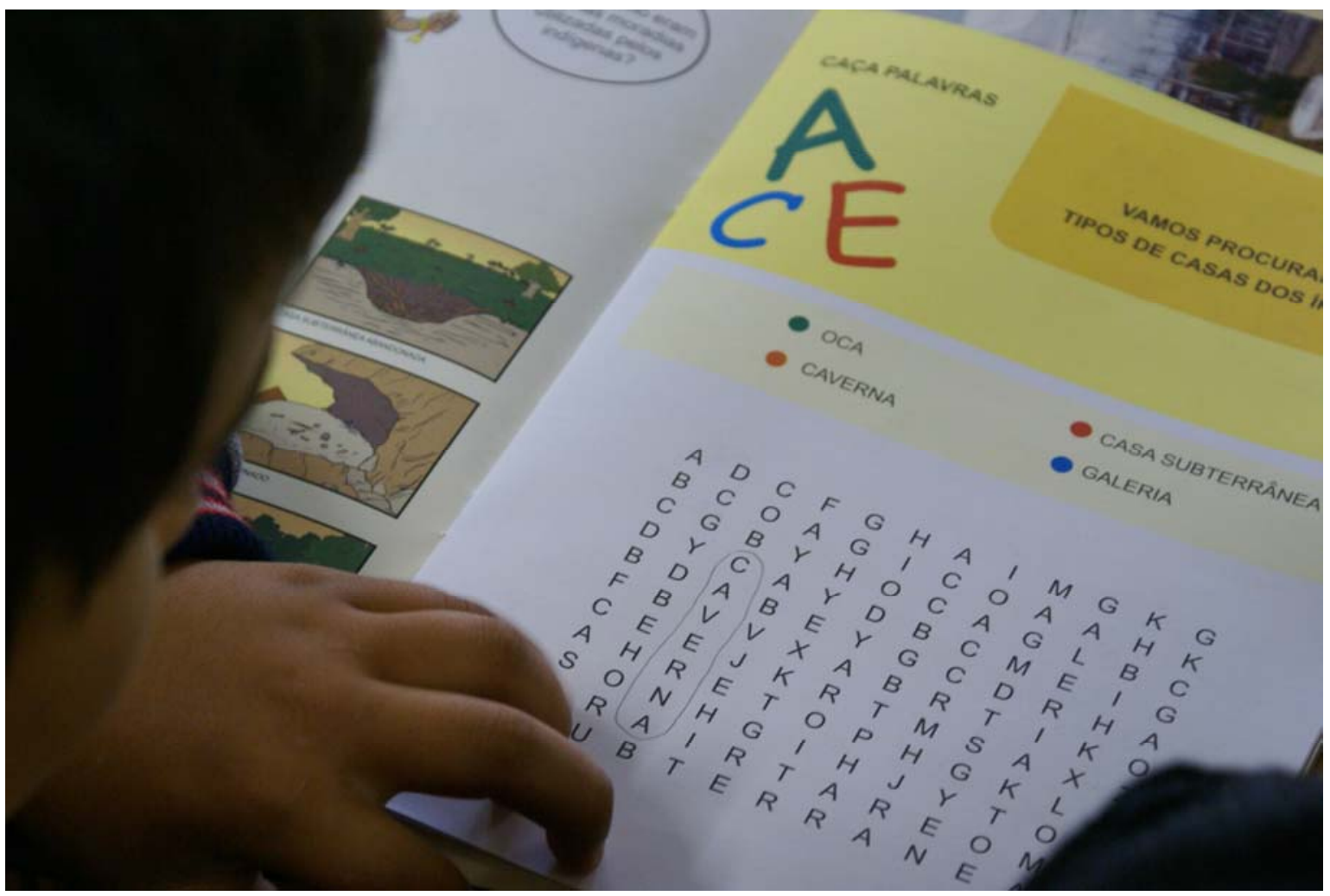

Figura 21 - Educação patrimonial: análise 


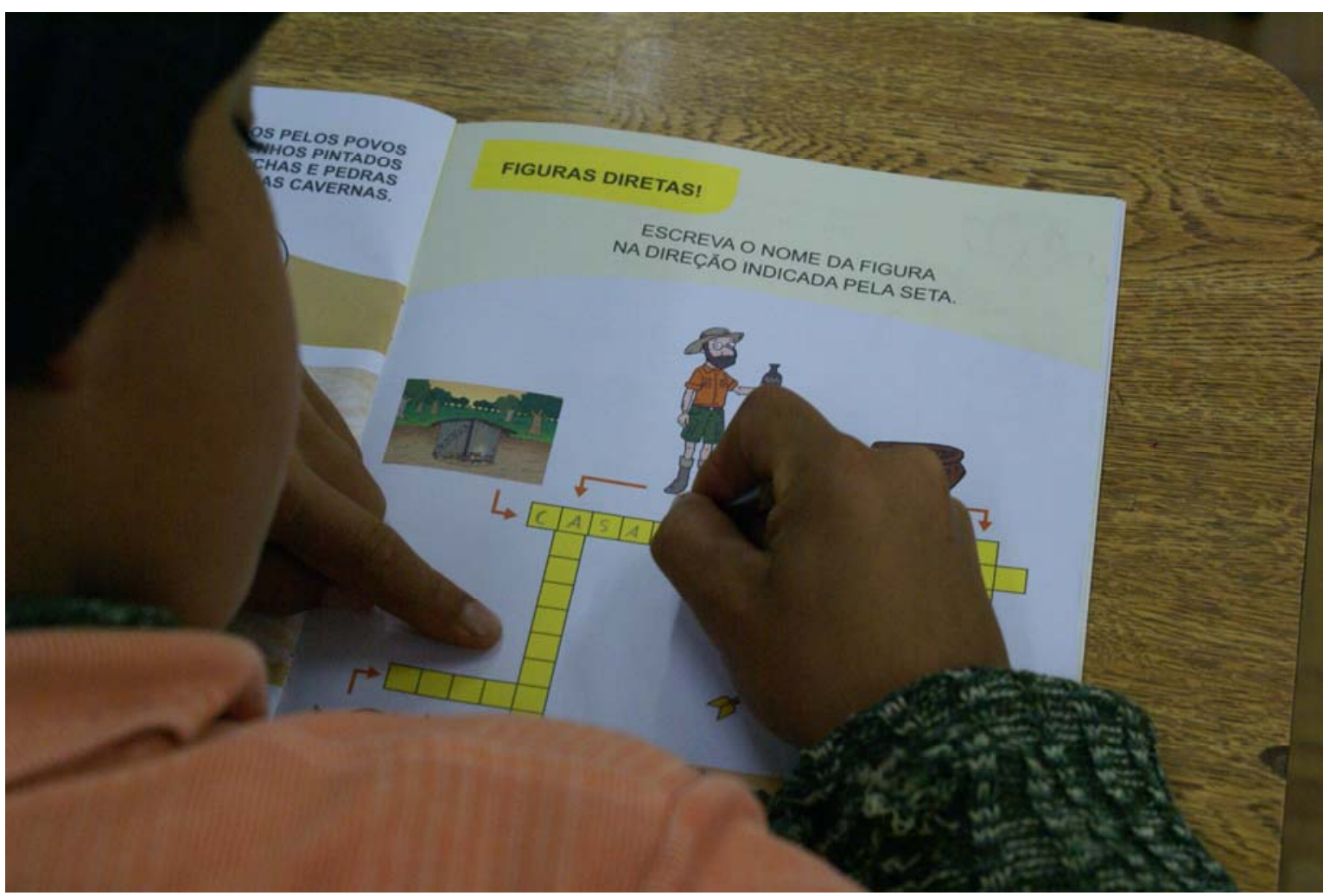

Figura 22 - Educação patrimonial: escrita

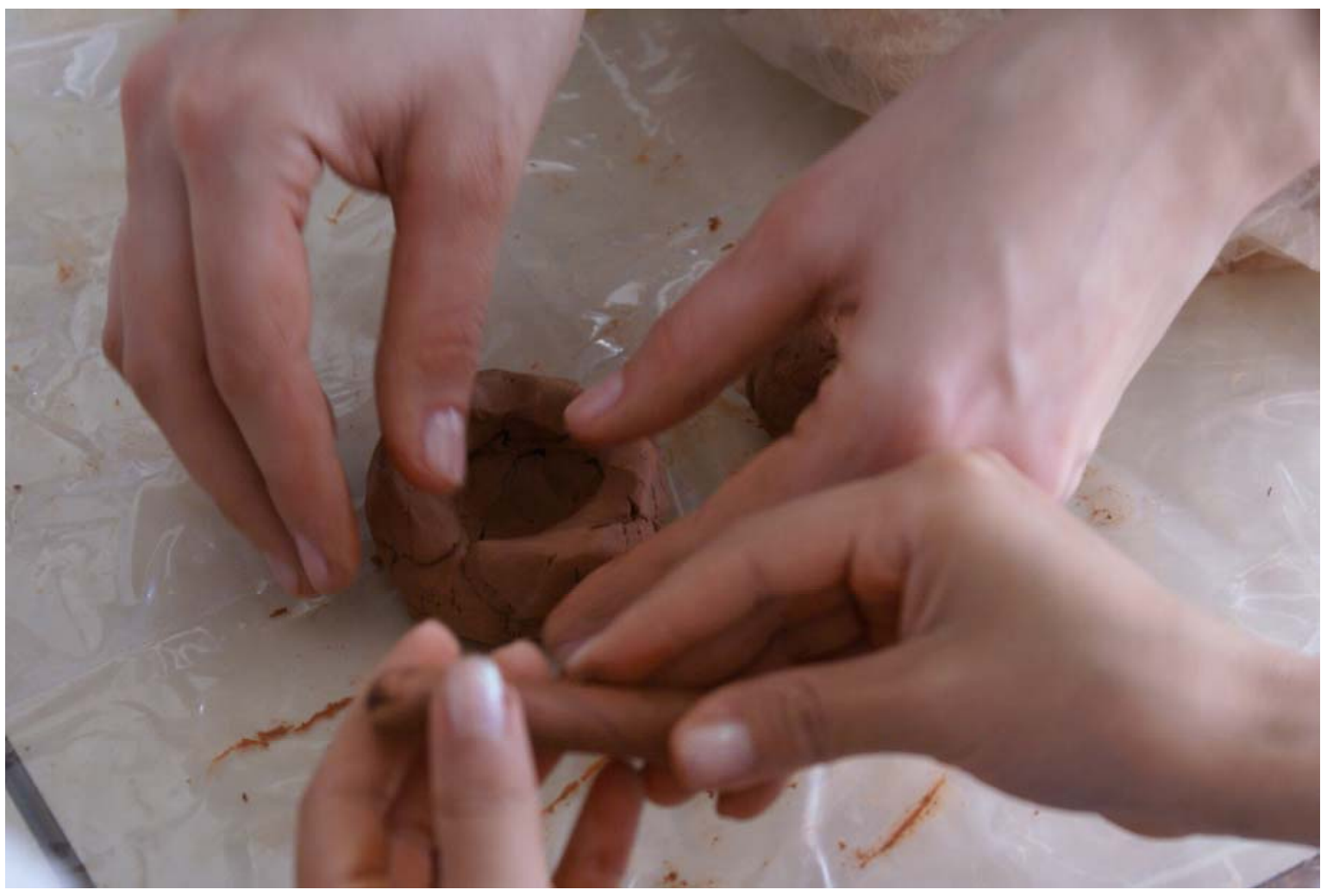

Figura 23 - Educação patrimonial: aprender a fazer 


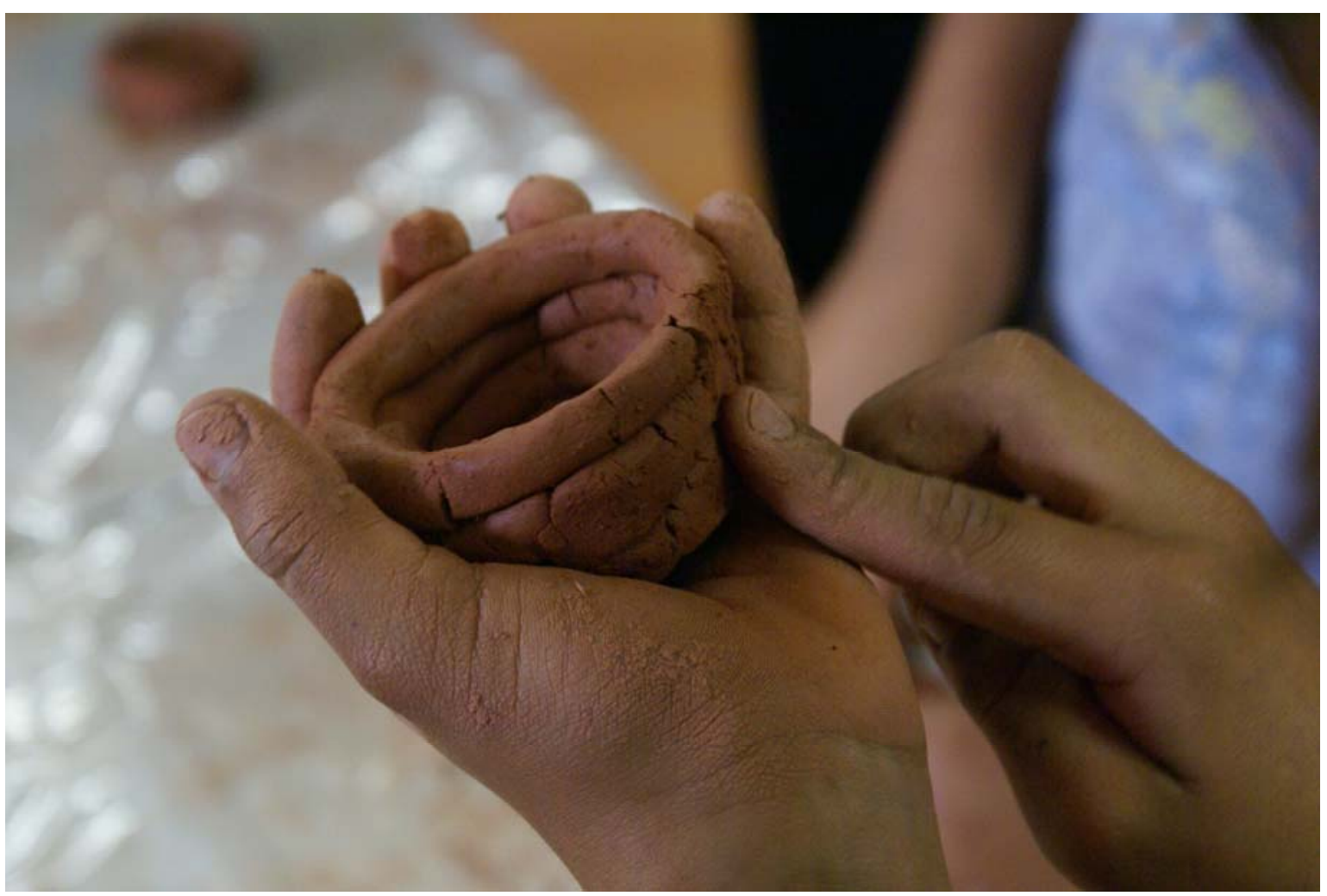

Figura 24 - Educação patrimonial: execução

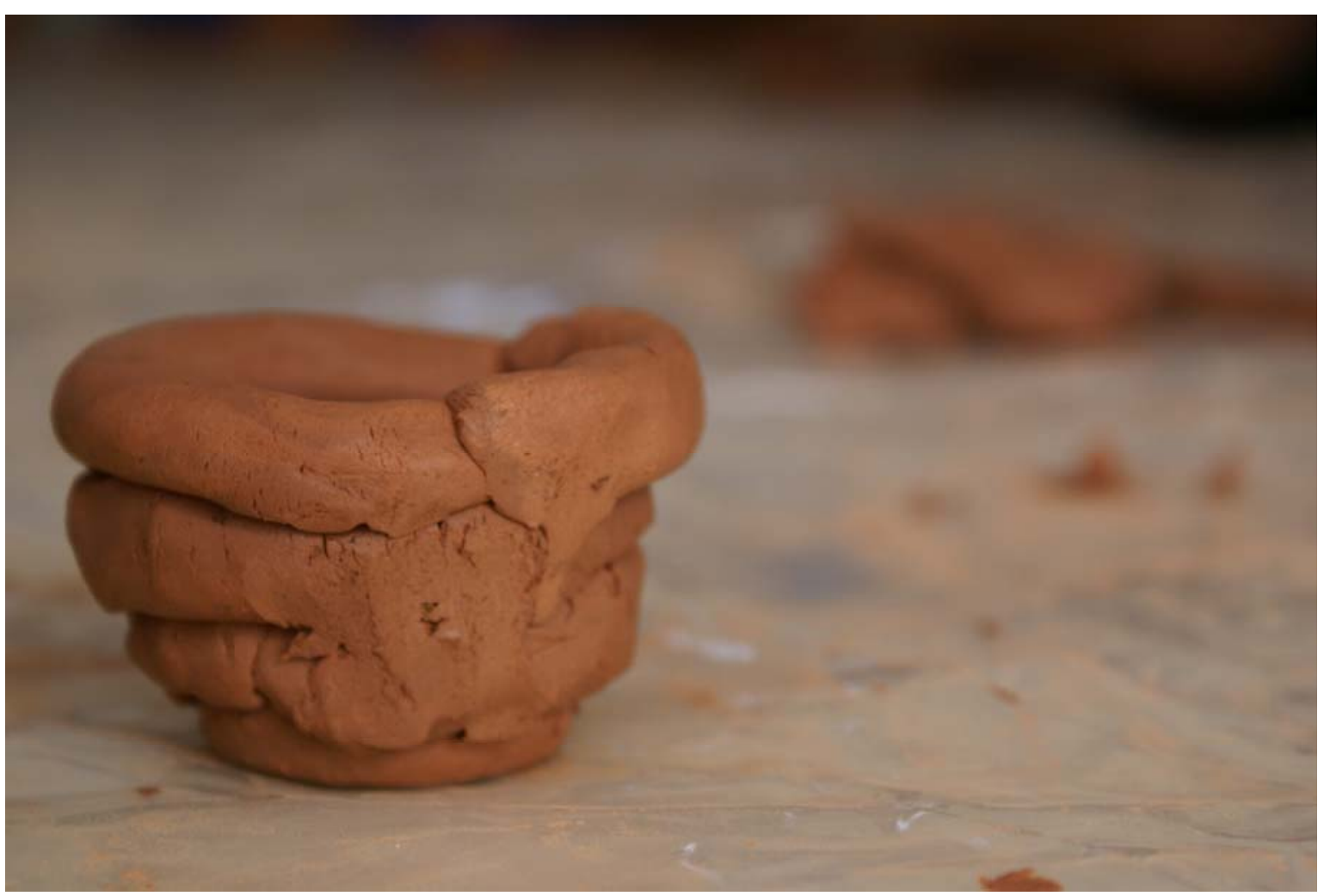

Figura 25 - Educação patrimonial: resultado da prática 


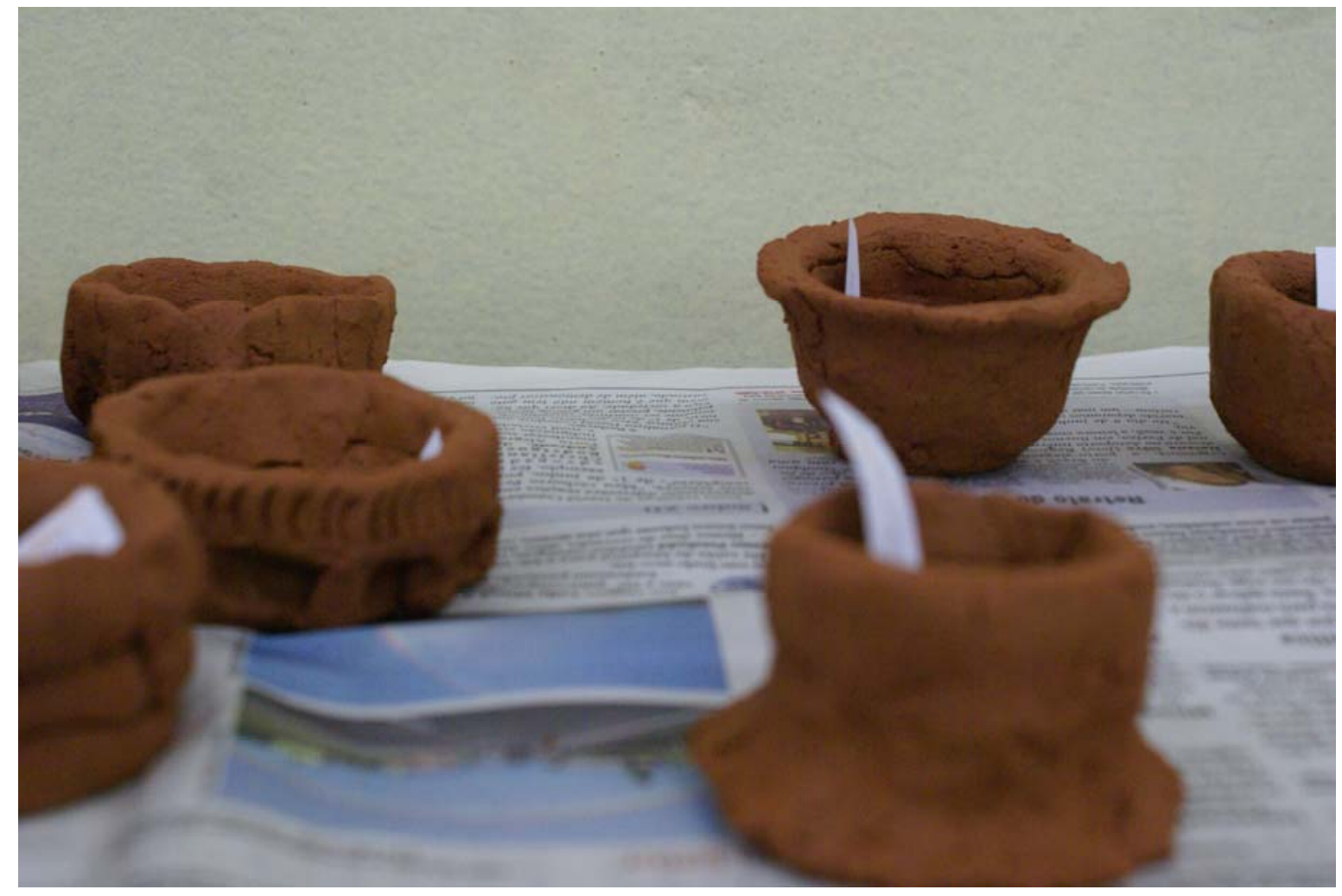

Figura 26 - Educação patrimonial: exposição

Nessa concepção, o processo educacional supera a consciência ingênua, possibilitando uma educação investigadora, dialógica e crítica; desenvolvendo aptidões para contextualizar, por meio do pensamento complexo, todo acontecimento, informação ou conhecimento em relação ao meio cultural, social, econômico, político e natural, e desvendando as relações que subjazem aos fenômenos. Assim, é preciso pensar a educação a partir de nexos, de necessidades humanas e sociais concretas, refletindo diretamente nos processos vitais e de conhecimento (MORIN, 2000).

A materialização da arqueologia preventiva proposta por Morais ultrapassa o cunho meramente teórico. Em observação num de seus trabalhos na LT500 kV Bateias-Ibiúna ${ }^{63}$, verifica-se já nos objetivos do projeto uma clareza e a preocupação constante para com a legalidade que protege os bens arqueológicos

${ }^{63}$ Programa Estudo do Patrimônio Arqueológico, Arquitetônico e Paisagístico da LT 500 kV Bateias-lbiúna, fase II - Resgate e Preservação do Patrimônio Arqueológico e Arquitetônico, abrangendo trechos dos estados do Paraná e de São Paulo, de propriedade de Furnas Centrais Elétricas, empresa pública do setor elétrico responsável pela geração e transmissão de energia. 
e o resguardo para com os padrões científicos. Morais especifica nos objetivos do

Projeto da LT Bateias/ Ibiúna o seguinte:

\begin{abstract}
a] Estudar os sistemas regionais de povoamento indígena, das situações de contato inter-étnico e das frentes pioneiras da sociedade nacional, considerando as expressões materiais da cultura contidas nos registros arqueológicos pré-históricos e históricos da área de influência do empreendimento, incorporando-os à memória regional e nacional, evitando perdas patrimoniais frente a sua construção.

b] Registrar, do ponto de vista patrimonial, os arranjos espaciais e a arquitetura formal e vernacular ${ }^{64}$ da área de influência do empreendimento, compondo um banco de informações a respeito da construção e manejo do território e sua evolução.

c] Registrar, do ponto de vista patrimonial, o ambiente físico-biótico e o território de manejo de recursos econômicos dos povos indígenas, das situações de contato inter-étnico e das frentes pioneiras da sociedade nacional presentes na região, tentando recompor os antigos cenários das ocupações humanas.
\end{abstract}

\title{
Observa-se que os objetivos são justificáveis pela própria idéia do
} escopo do programa quando enumera:

a] Planejamento e execução dos procedimentos na perspectiva da arqueologia da paisagem, valorizando suas propriedades inerentes à gestão do patrimônio arqueológico.

b] Otimização do uso das geotecnologias disponíveis, com ênfase no georreferenciamento por meio do sistema de posicionamento global e na interpretação de registros de sensoriamento orbital e sub-orbital para o mapeamento de compartimentos da paisagem potencialmente aptos a apresentarem assinaturas antrópicas de povos do passado.

c] Interpretação e consolidação dos dados integrados em um SIG Sistema de Informações Georreferenciadas.

d] Consolidação dos itens patrimoniais significativos detectados na fase I -Levantamento do Patrimônio Arqueológico, Arquitetônico e Registro da Paisagem, a serem objeto de intervenções ou de abordagens mais detalhadas, considerando os estágios de campo correntes da arqueologia da paisagem.

e] Implementação da fase II - Resgate e Preservação do Patrimônio Arqueológico e Arquitetônico, com a adoção dos procedimentos correntes de intervenção e análises avançadas abrangendo geoindicadores (inclusive cavidades naturais), registros arqueológicos, demais arranjos espaciais e elementos da arquitetura formal e vernacular, em grau e intensidade adequados às questões e hipóteses formuladas para a região.

f] Introdução de ensaios relativos à implementação de estudos de arqueologia da arquitetura, explorando as possibilidades de interface entre as duas disciplinas.

64 Citação minha: Próprio da região em que está; nacional (HOLANDA, 2003). 
g] Análise dos materiais arqueológicos coletados, com o propósito de se reconhecer as cadeias operacionais da sua produção, indicando o potencial de uso em processos educativos.

h] Processamento dos materiais decorrentes das abordagens interdisciplinares, incluindo aqueles relacionados com a obtenção de datações [amostras arqueométricas] e com análises do ambiente físicobiótico [amostras geoarqueológicas e bioarqueológicas].

i] Planejamento e execução de ação-piloto de educação patrimonial.

j] Elaboração de relatórios técnico-científicos e preparação da publicação.

No escopo proposto, observam-se ações ligadas ao planejamento estratégico do empreendimento e aos princípios da arqueologia da paisagem. As metas que foram propostas no desenvolvimento do escopo e persistiram até o final do projeto foram concretizadas.

a] Construir um banco de dados da arqueoinformação regional, incluindo o patrimônio arqueológico, o patrimônio arquitetônico e o patrimônio paisagístico, considerando as potencialidades da correlação entre esses segmentos.

b] Construir um banco de dados da geoinformação regional, incluindo a evolução da paisagem ao longo da área de influência indireta do empreendimento.

c] Consolidar um SIG - Sistema de Informações Georreferenciadas, com o propósito de armazenar, analisar e manipular a arqueoinformação e a geoinformação, considerando as seguintes assertivas: interface amigável com os usuários, entrada e integração de dados, funções de processamento, visualização e plotagem, armazenamento e recuperação de dados, devolução e inclusão social da arqueoinformação.

O autor considera que a utilização e o entendimento desses termos são a fase inicial e preliminar nos projetos de arqueologia preventiva, que permitem um olhar analítico sobre a realidade que circunda o empreendimento e/ou as pesquisas arqueológicas. O mais importante na compreensão da arqueologia preventiva está no reconhecimento tácito e incondicional de que a lei (nos termos já trabalhado anteriormente) é balizadora para os estudos de arqueologia. A lei é entendida como norma legal de um Estado democrático de direito, e, sobretudo, Morais entende o patrimônio arqueológico como bem difuso. 
Portanto, a proposta de gestão, entendida pela arqueologia preventiva como transitando e tendo como tônica a interdisciplinaridade e a transdisciplinaridade, concebe que "a produção de conhecimento acerca do patrimônio arqueológico envolve agentes muito variados, que transitam entre o cientista (titulado), que pensa, e o braçal (quase sempre sem escolaridade), que abre as trincheiras. Um ambiente propício para que se reconheça o significado e a relevância de cada um dos papéis. Só assim, o orgulho da autoria na produção da arqueoinformação poderá ser repartido" (MORAIS,2006, p.213). 


\section{A GESTÃO EM ARQUEOLOGIA DE PROJETOS}

6.1 O PDCA - P (Plan = Planejar $), \mathrm{D}($ Do = Executar $), \quad \mathrm{C}($ Check $=$ Verificar $), \mathrm{A}$ (Action = Agir), aplicado na Arqueologia .

No último item desta tese, o objetivo é propor a aplicabilidade da técnica do PDCA para os projetos de arqueologia, a fim de propiciar à ciência arqueológica procedimentos técnicos mínimos para a viabilidade dos projetos de arqueologia em instituições acadêmicas, privadas, públicas ou ONGs.

Como se observou no item anterior, a efetivação de um modelo de pesquisa para tratar a arqueologia foi desenvolvido e proposto por Morais contemplando aspectos da interdisciplinaridade e transdisciplinaridade e que a atenda às demandas contemporâneas, ligadas às normas e regras exigidas pela lei brasileira e, sobretudo, ofereça subsídios que permitam a inteiração/inclusão social da comunidade e sociedade civil que convivem com o patrimônio cultural e arqueológico.

Entretanto, com a ampliação de projetos e empreendimentos impactantes ao meio ambiente e arqueológico, proporcionou-se uma demanda efetiva de trabalhos, criando-se oportunidade para instituições clássicas, bem como empresas novas e organizações interessadas, e visualizou-se uma oportunidade de aprofundamento e reconhecimento da ciência arqueológica. Todavia, o oportunismo, o amadorismo e, sobretudo, a marca da má intencionalidade também ganharam espaço, o que possibilitou que alguns projetos se distanciassem dos seus reais objetivos: preservar, cuidar e divulgar o patrimônio arqueológico brasileiro. 
Muito desse "amadorismo" ocorreu e ocorre por falta de subsídios, nem sempre teóricos, pela dificuldade de administração e gestão seja dos e nos projetos, bem como das instituições/empresas/ organizações.

Antes de entrar na proposição do PDCA e na sua adaptabilidade, cabe ressaltar que, de forma muito louvável, o Instituto de Patrimônio Histórico e Artístico Nacional, através do Dr. Rossano Lopes Bastos, arqueólogo da $11^{\text {a }}$ Superintendência Regional, tem insistentemente divulgado aos empreendedores e profissionais da arqueologia a importância de uma boa gestão nos projetos, o que possibilita a garantia e a efetividade da conservação/proteção do patrimônio arqueológico brasileiro.

Bastos apresenta organogramas ${ }^{65}$ que mostram as diretrizes legais para o licenciamento arqueológico de contrato.

${ }^{65}$ Trabalho apresentado na Interncional Business Comunications em dezembro de 2001. 
Fase 01 - Baseado nas Diretrizes do DEPROT / IPHAN

Fase de Obtenção de Licença Prévia (EIA/RIMA)

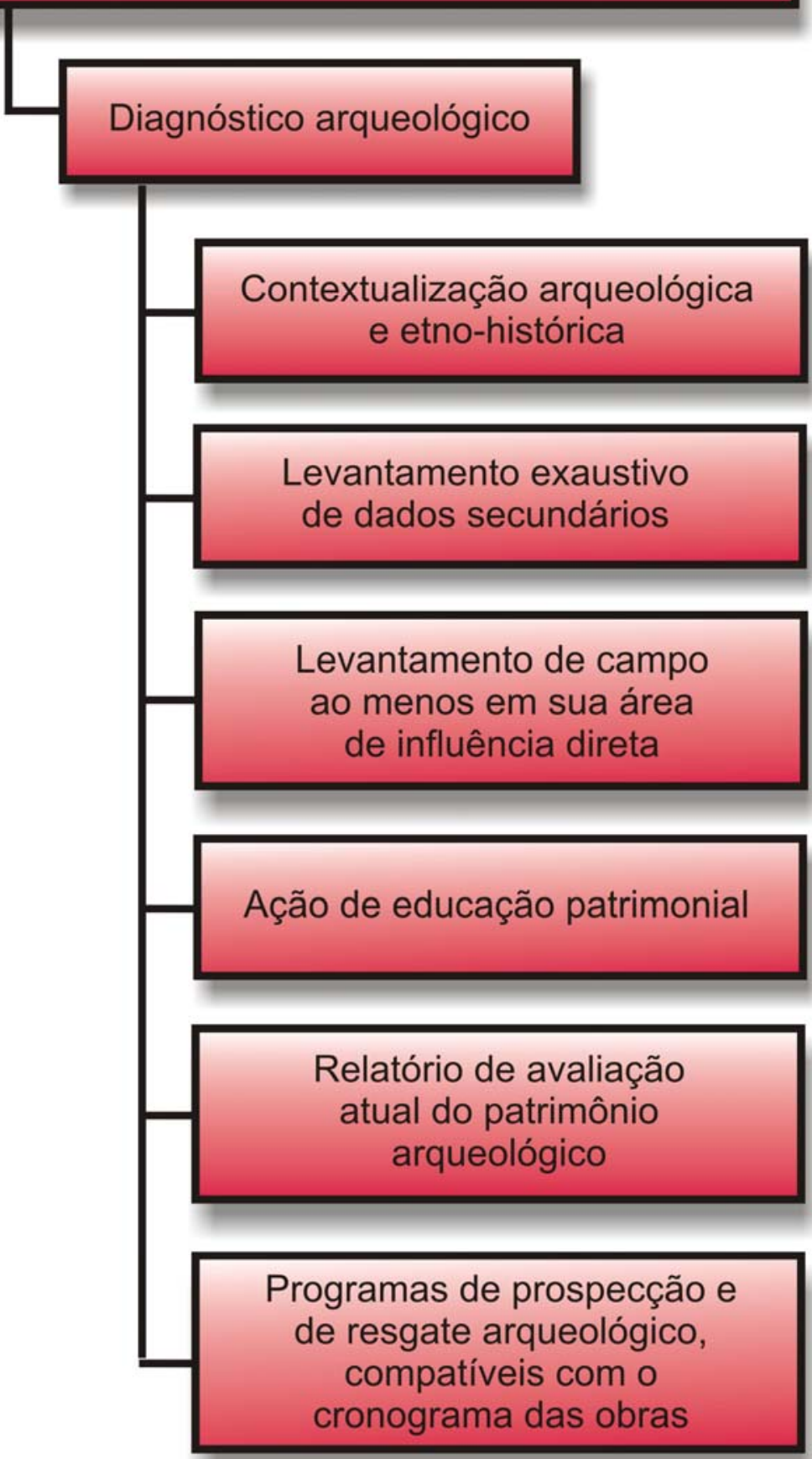

Figura 27 - Fase de obtenção da licença prévia 
Fase 02 - Baseado nas Diretrizes do DEPROT / IPHAN

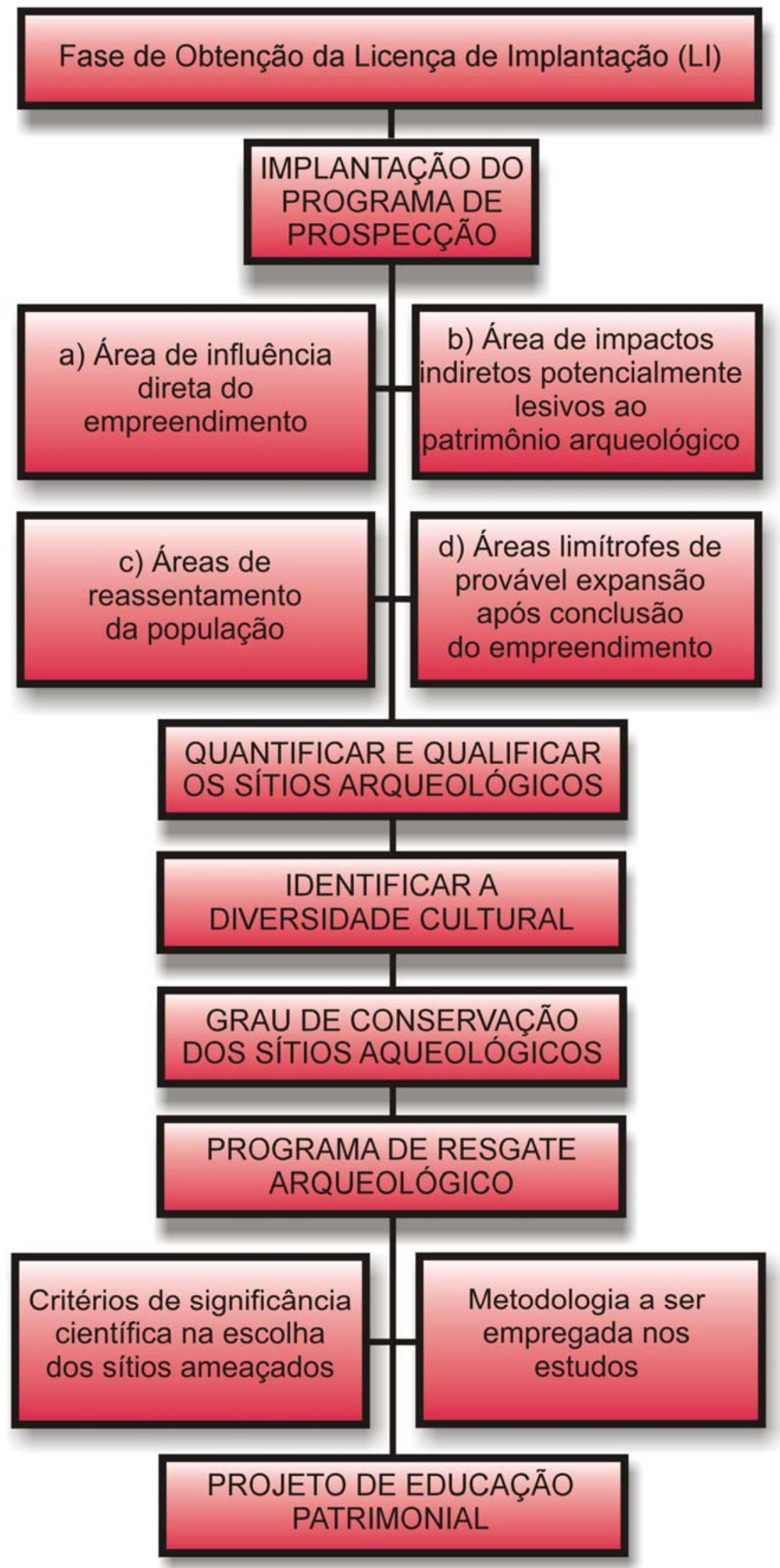

Figura 28 - Fase de obtenção de licença instalação 


\section{Fase 03 - Baseado nas Diretrizes do DEPROT / IPHAN}

FASE DE OBTENÇÃO DA LICENÇA DE OPERAÇÃO (LO)

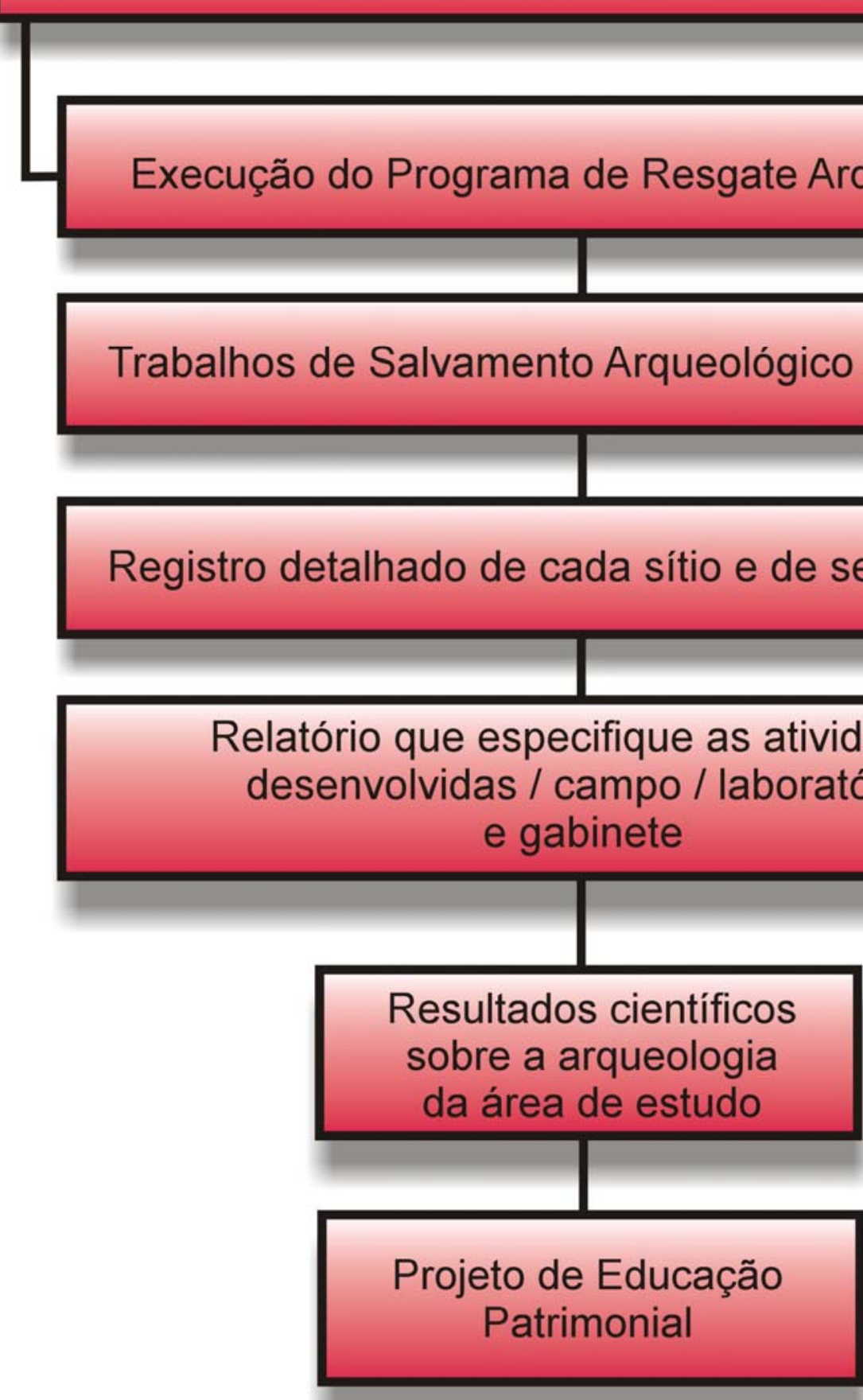

Figura 29 - Fase de obtenção da licença de operação 


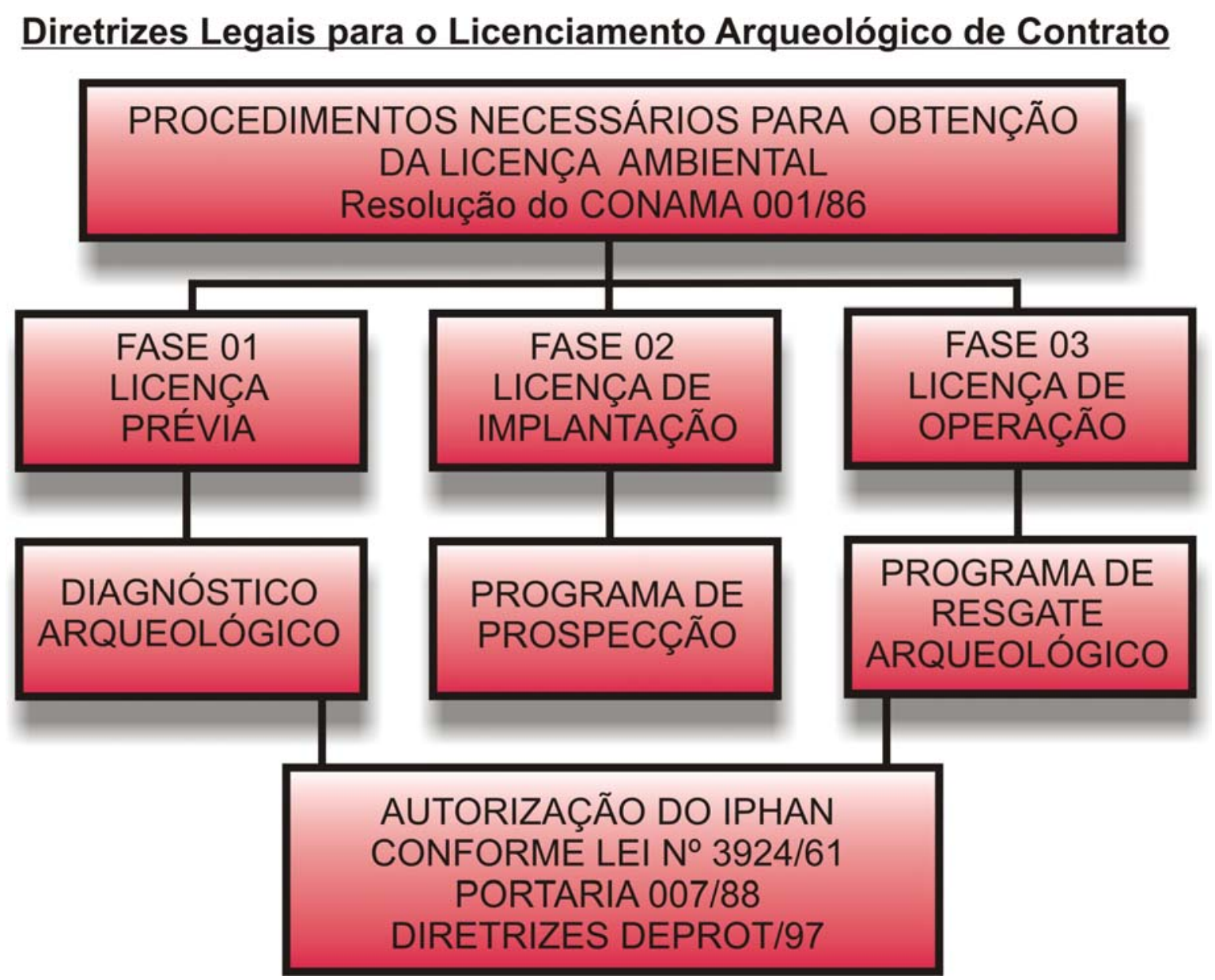

Figura 30 - Diretrizes legais para o licenciamento arqueológico de contrato

Mesmo com todo esse delineamento claro e seguro dimensionado nos organogramas, O IPHAN não consegue gerenciar a proteção dos bens arqueológicos, seja pelas dimensões geográficas do país, seja pela dificuldade estrutural. Para Bastos (2007, p.57), o IPHAN é uma "autarquia da União Federal, estabelece normas e procedimentos baseados na legislação. Podemos destacar que a norma geral não leva em conta a diversidade no campo cultural, como também não foi capaz de suscitar, por parte dos estados e municípios, uma legislação complementar adequada, em consonância com a norma constitucional".

Pode-se, num primeiro momento, entender, a partir da proposição expressa nos organogramas, que os aspectos gerenciais dos projetos de 
arqueologia estariam resolvidos, contudo a proposição expressa pelo autor, que segue o que o IPHAN orienta, consegue dimensionar os elementos gerais. $\mathrm{Na}$ operacionalidade, e aí, é o foco central desta tese, a complexidade é maior. Por isso, antes de propor a vinculação dos projetos à utilização da técnica do PDCA, têm-se alguns elementos a serem considerados sobre o que está ocorrendo na execução dos projetos atuais.

Tem ocorrido:

1. aumento de empreendimentos impactantes ao meio ambiente - isso não é novidade para a sociedade arqueológica, contudo estes, na sua maioria, têm encarado a arqueologia como uma "pedrinha no sapato" do empreendimento;

2. surgem, em decorrência do item anterior, várias empresas prestadoras de serviços, universidades, ONGs, que passam a focar suas atuações para este "nicho de mercado".

3. nem todas as mencionadas estão preparadas para atuar no chamado mercado novo ${ }^{66}$. Por quê?

a. possuem dificuldades técnicas e científicas para dar abrangência em curto prazo das demandas (licença) dos empreendimentos;

b. não conseguem mensurar os custos de operacionalidade de uma equipe em campo e os tributos legais a serem pagos ao Estado;

c. a infra-estrutura é limitada pelo grau de exigência dos empreendedores. Ex. equipamentos de segurança etc.;

d. levam a campo alunos, estagiários sem os devidos procedimentos legais de registro trabalhista;

e. remuneração abaixo do mercado e de forma temporária, o que caracteriza precarização nas relações de trabalho;

4. a partir dos subitens elencados cobram dos empreendimentos preços abaixo da real efetivação dos seus custos;

5. não fazem análise de custos $^{67}$ como:

\footnotetext{
${ }^{66}$ Ver conceito de acumulação flexível mencionado anteriormente.

${ }^{67} \mathrm{O}$ que deve ser dispendido (em dinheiro, tempo, esforço, etc.) para se obter algo (HOLANDA, 2003)
} 
a. impostos, taxas, contador, aluguel;

b. encargos sociais sobre a folha de pagamento quando há folha;

c. depreciação de equipamentos, veículos, estrutura física;

6. montam-se os valores das propostas depreciando o trabalho dos colegas de arqueologia.

Observa-se que como a arqueologia não possui um órgão de categoria e regulador entre os seus pares, facilita-se que os empreendedores, na sua maioria, visualizem-na como categoria desorganizada, permitindo barganhas e causando certa depreciação de alguns projetos e trabalhos. Agregado a isso, a dificuldade de as empresas, ONGs, universidades dimensionarem valores para os projetos provoca questionamentos dos empreendedores de longa data. Em 1996, no simpósio de Goiânia Mauricio $\operatorname{Taan}^{68}$ (p.43), referindo-se aos projetos de arqueologia, afirmou:

\begin{abstract}
Eu sinto a falta da palavra custo (...) Então acho que vai chegar o momento, não sei se é agora, não sei se vai ser daqui a dois anos a três anos, que as pessoas vão ter que começar a falar em custos. Desculpemme se estou profanando. Há algum tempo já trabalhei em pesquisa, fui professor da UFRJ durante muitos anos, e sei como as pessoas se sentem quando a gente põe a palavra custos; que o custo é uma coisa que nos joga na frente do espelho, que a gente tem que olhar a eficiência. Então, acontece o seguinte: a gente confunde eficiência com eficácia, a gente confunde um a série de conceitos, a gente sai trabalhando, sai fazendo as coisas, e o custo trazem muitas realidades para nós, traz muitos questionamentos sobre porque determinados fenômenos, quando a variável tem de ficar no infinito, você justifica tudo, você converge no infinito e todo trabalho é bom. Se você pode ter infinito tempo, infinitos recursos, qualquer trabalho acaba sendo feito. (p.43)
\end{abstract}

As afirmações de Mauricio Taan estão tão latentes na atualidade dos projetos de arqueologia, que a pressão para o tempo de entrega dos projetos é cada vez mais acentuada de parte do empreendedor ou do próprio pesquisador. $\mathrm{Na}$ maioria das vezes, este só receberá financeiramente pelo seu trabalho à

\footnotetext{
${ }^{68}$ Mauricio Taan foi debatedor da mesa "O Uso de Modelos Preditivos para diagnosticar recursos Arqueológicos em áreas a serem afetadas por empreendimentos de impacto ambiental. $\mathrm{Na}$ época pertencia do departamento de Meio Ambiente de Furnas Centrais Elétricas.
} 
medida que for liberando a área para o empreendimento ou quando entregar o relatório final.

Objetivamente, percebe-se que as dificuldades para mensurar custos de um projeto perpassam não só pela capacidade do arqueólogo de entender da sua área específica, mas, precisamente, de entender a logística ${ }^{69}$ do empreendimento e os interesses políticos, regionais e econômicos envolvidos nesses.

Os profissionais mais conscientes, dependendo do empreendimento, conseguem se resguardar, estabelecendo em seus contratos cláusulas aditivas e de complementação, o que ameniza a "perda" do profissional e garante a conclusão dos trabalhos com garantias. No entanto, nem todos os empreendimentos têm essa sensibilidade para compreender a necessidade do arqueólogo e nem todos arqueólogos conseguem dimensionar realmente seus projetos, porque geralmente lhes faltam subsídios técnicos para pedir o aditamento de um contrato.

Tornar os projetos viáveis implica entender ferramentas de gestão que estão fora muitas vezes da alçada dos arqueólogos; para isso, ou agregam-se profissionais (que entendam da gestão) das áreas que demanda ou os arqueólogos devem procurar se aperfeiçoarem. Não significa que necessariamente o arqueólogo deva ter afinidade com a mesma, porém deverá entender a filosofia e os princípios da gestão a fim de obter melhores resultados.

Com isso, o PDCA - P (Plan = Planejar), D (Do = Executar), C (Check $=$ Verificar), $\mathrm{A}$ (Action $=$ Agir) aplicado na arqueologia serve como modelo que deverá estar associado à vontade política do gerenciador dos projeto. A vontade política a que se faz referência não está somente associada à "capacidade de escolha, de decisão (...) e da deliberação, decisão ou arbítrio que parte de entidade superior" (HOLANDA, 2003), mas, principalmente, associada, nesse sentido está a busca da essência do PDCA que é a "habilidade no trato das

69 Projeto e desenvolvimento, obtenção, armazenamento, transporte, distribuição, reparação, manutenção e evacuação de material (para fins operativos ou administrativos). 
relações humanas, com vista à obtenção dos resultados desejados ${ }^{70 \text { ". Para }}$ isso, apresentam-se quatro momentos a que o gestor deve proceder para tornar o PDCA aplicável em seus projetos.

PLANEJAR, EXECUTAR, VERIFICAR E AGIR NOS PROJETOS DE ARQUEOLOGIA

\section{PLANEJAR}

Definir o que se quer, planejar o que será feito, estabelecer metas e definir os métodos que permitirão atingir as metas propostas.

O contrato com o empreendimento ou concepção do projeto (acadêmico)

Arqueólogo (Gestor)

Gestor Financeiro
Neste caso, o conhecimento e a participação devem ficar restritos a estes profissionais, especificamente porque se trata de valores financeiros e de responsabilidades jurídicas (em nome de que ficará a portaria do IPHAN), a quem os empreendedores se reportarão e a quem a lei responsabilizará. Sabese que muitos arqueólogos acumulam estas duas funções.

Técnicos em

Arqueologia

Responsáveis que participarão na concepção e confecção do projeto que será apresentada ao IPHAN e ao empreendimento contratante, juntamente com o arqueólogo e o gestor financeiro.

Figura 31 - PDCA aplicável aos projetos de arqueologia - planejar

${ }^{70}$ Grifo meu 


\section{VERIFICAR}

Verificar os resultados que se está obtendo. Averiguar continuamente os trabalhos para ver se estão sendo executados conforme planejado.

\begin{tabular}{|c|c|}
\hline \multicolumn{2}{|c|}{ Desenvolvimento das Atividades de Campo e Laboratório } \\
\hline Arqueólogo (Gestor) & $\begin{array}{l}\text { Responsável pela consolidação dos relatórios } \\
\text { parciais e finais. Responde junto ao } \\
\text { empreendimento e responder junto ao IPHAN pelo } \\
\text { desenvolvimento dos trabalhos }\end{array}$ \\
\hline Gestor Financeiro & $\begin{array}{l}\text { Responsável pelo desembolso financeiro para } \\
\text { operacionalidade do campo, pelo pagamento dos } \\
\text { profissionais e pela cobrança junto ao } \\
\text { empreendimento. }\end{array}$ \\
\hline $\begin{array}{l}\text { Técnicos em } \\
\text { Arqueologia }\end{array}$ & $\begin{array}{l}\text { Gerencia as atividades de campo e laboratoriais. } \\
\text { Assume uma posição estratégica porque consegue } \\
\text { dimensionar o desenvolvimento do campo e } \\
\text { administra as relações interpessoais do grupo que } \\
\text { está em campo. }\end{array}$ \\
\hline $\begin{array}{l}\text { Funcionários, } \\
\text { Estagiários }\end{array}$ & $\begin{array}{l}\text { Nesta fase desempenham a função de contato } \\
\text { direto com o material arqueológico. }\end{array}$ \\
\hline
\end{tabular}

Figura 32 - PDCA aplicável aos projetos de arqueologia - verificar 


\section{EXECUTAR}

Tomar iniciativa, educar, treinar, implementar, executar o planejado conforme as metas e métodos definidos.

Treinamento e qualificação do projeto e reconhecimento das ADA e AIA

\begin{tabular}{|c|c|}
\hline Arqueólogo (Gestor) & $\begin{array}{l}\text { Qualificar o pessoal envolvido e gerenciar/ } \\
\text { consolidar os relatórios para os órgãos e os } \\
\text { empreendedores contratantes. }\end{array}$ \\
\hline Gestor Financeiro & $\begin{array}{l}\text { Cuidar da operacionalidade físico-financeira do } \\
\text { projeto e é responsável pelas contratações legais } \\
\text { dos profissionais, bem como impostos, despesas, } \\
\text { cobranças etc. }\end{array}$ \\
\hline $\begin{array}{l}\text { Técnico em } \\
\text { Arqueologia }\end{array}$ & $\begin{array}{l}\text { Coordena as equipes em campo e assegura o } \\
\text { desenvolvimento dos trabalhos. O papel deste } \\
\text { profissional é fundamental e tem uma interferência } \\
\text { significativa nos resultados, especialmente se o } \\
\text { papel de liderança for eficiente; caso contrário pode } \\
\text { comprometer os resultados e a integridade de } \\
\text { relacionamento da equipe. }\end{array}$ \\
\hline $\begin{array}{c}\text { Funcionários, } \\
\text { Estagiários }\end{array}$ & $\begin{array}{l}\text { Papel de desempenhar as atividades de campo, } \\
\text { laboratório e anotações em campo. A dificuldade em } \\
\text { manter esse pessoal como efetivo, de certa forma, é } \\
\text { o que tem causado o insucesso de alguns projetos, } \\
\text { visto que a cada nova contratação há necessidade } \\
\text { de recomeçar os treinamentos das partes } \\
\text { operacionais que compõem a logística da empresa, } \\
\text { causando certos atrasos no inicio dos trabalhos de } \\
\text { campo. O relacionamento com outras lideranças } \\
\text { deve ser recomeçado em cada etapa. }\end{array}$ \\
\hline
\end{tabular}

Figura 33 - PDCA aplicável aos projetos de arqueologia - executar 


\section{AGIR}

Fazer correções de rotas se for necessário, tomar ações corretivas ou de melhoria, caso tenha sido constatada na fase anterior a necessidade de corrigir ou melhorar processos.

Desenvolvimento das atividades de campo e laboratório

\begin{tabular}{|c|l|}
\hline \multirow{2}{*}{ Arqueólogo (Gestor) } & $\begin{array}{l}\text { Responsável pela consolidação dos relatórios } \\
\text { parciais e finais. Responde junto ao } \\
\text { empreendimento e junto ao IPHAN pelo } \\
\text { desenvolvimento dos trabalhos. } \\
\text { Avalia e, caso necessário, corrige o trabalho } \\
\text { desenvolvido. }\end{array}$ \\
\hline \multirow{2}{*}{ Gestor Financeiro } & $\begin{array}{l}\text { Responsável pelo desembolso financeiro para } \\
\text { operacionalidade do campo, pelo pagamento dos } \\
\text { profissionais responsáveis pela cobrança junto ao } \\
\text { empreendimento. Consolida os relatórios de } \\
\text { prestação de contas e desembolsos. }\end{array}$ \\
\hline Técnicos em & $\begin{array}{l}\text { Gerencia as atividades de campo e laboratoriais. } \\
\text { Assume uma posição estratégica porque consegue } \\
\text { dimensionar o desenvolvimento do campo e } \\
\text { administra as relações interpessoais do grupo que } \\
\text { esta em campo. Também tem a incumbência de } \\
\text { reaplicar ações não bem feitas e/ou dimensionadas, } \\
\text { sejam solicitadas pelo empreendedor, seja pelo } \\
\text { IPHAN. }\end{array}$ \\
\hline Funcionários, & $\begin{array}{l}\text { Nesta fase desempenham a função de contato } \\
\text { direto com o material arqueológico e lhes é dada a } \\
\text { oportunidade de começarem a produção científica. }\end{array}$ \\
\hline \hline
\end{tabular}

Figura 34 - PDCA aplicável aos projetos de arqueologia - agir 
Acredita-se que na proposição e a na adoção do PDCA não há posicionamentos contrários, contudo a decisão em optar por essa técnica passa pela transparência dos projetos. Para isso, é importante que o arqueólogo gestor assuma um posicionamento de liderança, a qual não se expande de forma mecanicista ou de maneira tediosa e imutável; é primordial que seja liderado, administrado de forma efetiva. O arqueólogo gestor deverá, com sua liderança, levar a que os participantes dos projetos de arqueologia busquem 0 comprometimento. Não que o arqueólogo fará tudo sozinho, mas, sim, orientará, conduzirá. "Sem uma boa liderança pouca coisa acontece. Uma boa liderança muitas vezes até compensa parcialmente a inexistência de um preparo técnico ou gerencial" (CAMPOS, 2005, p.12).

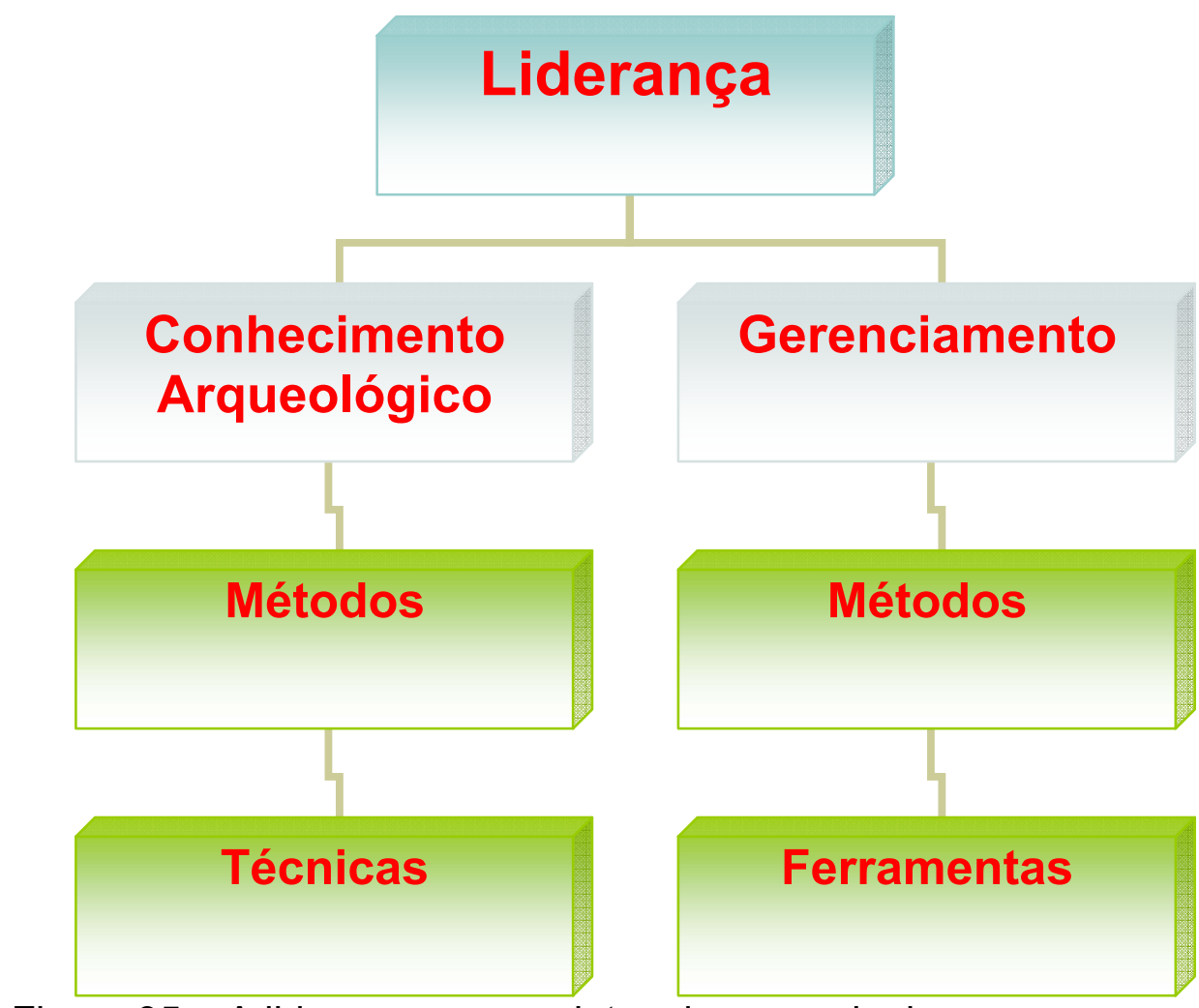

Figura 35 - A liderança nos projetos de arqueologia

O ciclo Liderança, Conhecimento Arqueológico (Métodos e Técnicas) e Gerenciamento (Métodos e Ferramentas) permite uma real análise 
e a medição dos projetos de arqueologia e é muito relevante para a manutenção e melhoria desses, contemplando, inclusive, o planejamento, a padronização e a documentação destes. São papéis que o arqueólogo e a sua equipe, quando bem preparados, conseguem desempenhar a fim de atingir as metas e os resultados desejados. A consciência do arqueólogo e sua equipe, aliada ao domínio dos vários conhecimentos e instrumentos de gestão existentes, fornece, ainda, ao arqueólogo a percepção de que sua função é de orientar no bom resultado do projeto. Com essa visão sistêmica e, portanto, participativa nos projetos de arqueologia, comprova que somente em equipe é possível ter pleno sucesso nos resultados.

Com o PDCA, a figura do arqueólogo, com caráter impositivo, "PHDeuses", que se sustentava na hierarquia, na distância, no temor e no conflito, deve ser substituída pela imagem do arqueólogo gestor, que conduz pela legitimidade, respeito, reconhecimento e admiração que a liderança deve despertar. "Associado a esse está o princípio que propõe a eliminação do medo, no sentido de favorecer a liberdade de expressão de idéias, de crítica, de sugestões e de exposição de dúvidas, imprescindível para criar o clima de colaboração e de cooperação desejado" (LARANGEIRA, 1997, p.184). A valorização que o arqueólogo deve dar à equipe caracteriza-o como apto a influenciar um comportamento positivo nos demais membros do projeto arqueológico. Um arqueólogo gestor não apenas precisa de boa equipe, mas que ela se aprimore constantemente. Tem-se percebido que as novas gerações de arqueólogos, na sua maioria, querem mais do que dinheiro; querem oportunidades crescentes de contribuir com algo à sociedade. Prova disso é que no XIV Congresso de Arqueologia da Sociedade de Arqueologia Brasileira (Sab), ${ }^{71}$ de setembro de 2007 -Florianópolis SC, $70 \%$ de participantes ligados à arqueologia eram jovens.

Ao arqueólogo gestor, entendido seu papel de nova liderança, plagiando Deming, podem-se aplicar os 14 princípios norteadores da qualidade em projetos de arqueologia:

${ }^{71}$ Congresso de que tive a oportunidade de ser coordenador executivo. 


\section{4 princípios norteadores da qualidade nos projetos arqueologia}

1. Constância nos objetivos de preservação do patrimônio arqueológico e cultural

2. Adoção da nova postura cientifica - aberta e sem restrições a divulgação

3. Introdução do principio da qualidade desde o primeiro estágio dos projetos de arqueologia

4. Fidelidade ao bem arqueológico/bem público

5. Melhoria constante dos procedimentos de pesquisa e na prestação de serviço

6. Treinamento no local dos projetos

7. Delegar a liderança de campo e pesquisa responsabilidade e créditos nos projetos

8. Abolição do medo nos projetos

9. Supressão de barreiras, entre os doutores ("phdeuses") e demais membros da equipe

10. Supressão de slogan e dizeres demagógicos para os membros das equipes

11. Pagar corretamente os valores combinados com os membros das equipes

12. Garantir que a equipe possa se orgulhar de seu trabalho

13. Estabelecer programas de educação e auto-aprimoramento

14. Incentivar o engajamento em todo conjunto do projeto de pesquisa

Figura 36 - 14 princípios norteadores da qualidade nos projetos arqueologia

A utilização desses princípios agregados à gestão nos projetos de arqueologia, já mencionada, conduz à busca por uma melhor qualidade destes, contudo não se devem esperar resultados a curto prazo, porque o fator educativo e de absorção dos arqueólogos e suas equipes é demorado e gradativo. Até porque é rara a empresa, organização, ONGs ou universidade que possui um 
quadro de arqueólogos e técnicos em arqueologia homogêneo e que tenha a facilidade de assimilar o PDCA.

Os arqueólogos e suas equipes que optam pelo desenvolvimento do Planejamento, Execução, Verificação e pela Ação tem de ter clareza de que nesses procedimentos o tempo é o acontecimento fundamental no aprendizado das pessoas. Todavia, é necessário que a equipe tenha resultados abundantes no desenvolvimento dos trabalhos e, com isso, animem-se para as fases seguintes. O arqueólogo é professor, colega, líder, e as suas ações, um processo de aprendizado. "A meta é a força motriz e os resultados, o prêmio maior do aprendizado. O mercado só compra resultados" (CAMPOS, 2005, p.12).

E a responsabilidade para com esses resultados? A essa responsabilidade que se chama responsabilidade social arqueológica (RSA), que se vincula ao conceito de que a responsabilidade social arqueológica deve ser resultante da ampliação das posturas éticas que estão intrínsecas no desenvolvimento dos projetos de arqueologia ${ }^{72}$. O desmembramento deste conceito percebe-se nos:

1. programas de educação patrimonial, entendidos não somente como reproduções de cursos para professores e alunos, mas sim com o desenvolvimento e a produção de material didático-pedagógico como livros, cartilhas, folder, atividades lúdicas, etc; ( figuras

2. programa de musealização, com o acervo depositado nas instituições cedentes dos endossos institucionais;

3. proporcionar ao empreendedor resultados que the possibilitem reverter em ações que aparecerão em seus balanços sociais;

4. incentivar e possibilitar ao quadro profissional arqueológico ações de qualificação profissional, como incentivo (com subsídios financeiros) ao estudo universitário, cursos técnicos, congressos;

5. mobilização para o reconhecimento da profissão de arqueólogo por meio de um conselho próprio, caso não seja possível, neste

${ }^{72}$ Grifo meu 
momento, procurar agregar-se ao CREA órgão consolidado e representativo;

6. fortalecimento da Sociedade de Arqueologia Brasileira (SAB) como instituição de fomento aos debates acadêmicos e científicos;

7. subsidiar o IPHAN e os demais órgãos de fiscalização e proteção do meio ambiente com material e resultados para divulgação dos projetos de arqueologia. Esse material não deve se caracterizar unicamente pela apresentação dos relatórios e, sim, material complementar para divulgação.

8. alimentar de forma correta e efetiva o Cadastro Nacional de Sítios arqueológicos; para isso, fomentar junto ao IPHAN, que a inserção dos dados seja feita via on-line e sob responsabilidade jurídica do arqueólogo.

A responsabilidade social arqueológica proposta e mencionada não se refletem única e exclusivamente como postura de inclusão social dos projetos de arqueologia ou como soluções que irão resolver problemas sociais e diminuir as indignações. Deve ser encarada como propostas para as lideranças em projetos de arqueologia assumirem a responsabilidade de compartilhar os problemas e soluções junto a seus membros de equipe e instituições. Com isso, a idéia de que somente a instituição é responsável social pelas ações praticadas começa a ser superada. "Por exemplo, a responsabilidade dos empregados e também de outros participantes na empresa é um conceito que, gradualmente, tem ganhado espaço nas legislações nacionais" (MATTIOLI,2003p, 2).

Não basta sustentar que a responsabilidade social arqueológica é única e exclusiva do arqueólogo gestor do projeto. Ela está intimamente relacionada com o corpo de relações que o arqueólogo oferece ou participa aos seus membros de equipe ${ }^{73}$. Nesse sentido, responsabilizar-se pelo projeto de arqueologia não é apenas tarefa do arqueólogo e/ou organização, mas de todos

${ }^{73}$ Para isso, acontecer o arqueólogo necessita que os membros de sua equipe estejam legalmente integrados, isto é, por ex. carteira assinada, garantias sociais, pagamentos em dia, etc, etc. 
os colaboradores do projeto. Neste caso, os atos educativos que devem ser desenvolvidos pela gestão do projeto, além de esclarecedores sobre a preservação ou precaução para com o bem arqueológico, devem constituir uma prática constante, isto é, diariamente o cuidado para com o bem arqueológico deve fazer parte da política administrativa do projeto arqueológico.

Portanto, o modelo proposto (PDCA) neste capítulo não assume a postura de uma panacéia, mas instrumentaliza a ciência arqueológica e lhe dá a possibilidade de sair das reservas acadêmicas do conhecimento, por outro lado, "joga-se nos braços da sociedade" e tira a arqueologia das hipóteses vagas e a passa para a operacionalidade dessas hipóteses. Dessa forma, precisar-se-á de uma gestão eficiente e eficaz. 


\section{CONSIDERAÇÕES FINAIS}

O ato de ensinar fornecer uma cultura que permita distinguir, contextualizar, globalizar os problemas multidimensionais, globais e fundamentais, e dedicar-se a eles.

Edgar Morin 


\section{CONSIDERAÇÕES FINAIS}

A trajetória percorrida neste trabalho não assumiu a postura de ser apenas uma revisão bibliográfica ou uma compilação de citações de notoriedades da ciência arqueológica. Procurou-se traçar um caminho que apontasse alternativas e proporcionasse elementos como subsídios para os iniciantes nos projetos de arqueologia e também para os mais experientes na ciência arqueológica.

Procurou-se entender a arqueologia e a gestão como elementos fundamentais no convívio da ciência arqueológica acadêmica e a arqueologia vinculada ao licenciamento ambiental. O elemento estabelecedor desse convívio entre ambos não perpassa pelos elementos da ciência em si, mas pela capacidade de gerenciamentos e aplicabilidade da ciência arqueológica. Para que isso aconteça é fundamental que a gestão dos projetos seja bem conduzida, que em ambos os casos permeie a inter e a transdisciplinaridade, pois, entendidas em suas especificidades, deve-se "recorrer ao jogo das interações, a enfrentar as complexidades, em vez de cedemos aos maniqueísmos ideológicos ou as mutilações tecnocratas, que reconhecem apenas realidades arbitrariamente compartimentadas, que são cegas ao que não é quantificável e ignoram as complexidades humanas" (MORIN, 1993, p.25).

O caminho percorrido pela reflexão conduz à conclusão de que a gestão assume um papel interdisciplinar por ter se envolvido em áreas que contemplam mais a complexidade subjetiva das ciências humanas do que a capacidade produtiva das organizações.

O meio ambiente é um bem difuso, assim, a legislação assegura a todos o direito ao meio ambiente equilibrado. Impõe-se, pois, através do poder público e da coletividade, o dever de defendê-lo e preservá-lo para a presente e 
as futuras gerações. O direito do ambiente é, por sua vez, distinto do direito meramente ecológico, pois compreende a proteção do patrimônio natural ou ambiental e cultural. Com isso, rompe-se com o pragmatismo da lei pela lei e vaise buscar nos conceitos básicos da ciência e na visão crítica dos fatos a sua sustentação.

A lei normatiza e orienta de forma persuasiva, mas, na maior parte, 0 faz de maneira coercitiva, pois objetiva garantir elementos de legitimidade $e$ garantias para a proteção do meio ambiente e do patrimônio cultural. Viu-se que a "diferença" entre a arqueologia acadêmica e a arqueologia de contrato não está nas suas bases conceituais, mas na capacidade de integrar as diversas áreas na operacionalidade dos seus projetos.

A arqueologia preventiva, em suas proposições, demonstra claramente que a interface entre o pensar arqueológico acadêmico puro e o da arqueologia vinculada ao licenciamento ambiental deve ser interdisciplinar e transdisciplinar. Para isso, demonstra que o vínculo com outras áreas, como a geografia, por exemplo, favorece significativamente a qualidade dos projetos arqueológicos e, sobretudo, dá uma visibilidade e respeito maior à ciência arqueológica.

Com isso, com a proposta do PDCA - P (Plan = Planejar), $\mathbf{D}($ Do = Executar), $\mathbf{C}$ (Check = Verificar), $\mathbf{A}$ (Action = Agir), aplicada na arqueologia, procurou-se fundamentar a necessidade por que passa a arqueologia na atualidade, que não é de incapacidade teórica ou falta de pensadores, mas, sim, de capacidade gerencial dos projetos de arqueologia, e que a adoção de um método não depende do título, da cor, da raça de quem o pratica, mas, fundamentalmente, da vontade política, a qual está associada à capacidade de escolha, de decisão e de deliberação e, principalmente, à habilidade no trato das relações humanas, com vista à obtenção dos resultados desejados. São resultados que passam a criar a responsabilidade social arqueológica (RSA), que deve ser resultante da ampliação das posturas éticas que estão intrínsecas no desenvolvimento dos projetos de arqueologia. Portanto, o Planejar, Executar, Verificar e a ação - PDCA não tem a intenção de fechar-se num modelo acabado e pronto, mas, com seus instrumentos, de possibilitar que as hipóteses 
levantadas nos projetos de arqueologia saiam da postura meramente teórica e sejam aplicadas à realidade.

A defesa do patrimônio arqueológico e do conhecimento arqueológico é, portanto, um dever social e elemento de luta através de elos de comprometimento de arqueólogos, sociedade civil e governantes. Porém, esse compromisso deve se estender a todos os cidadãos e não se limitar a uma minoria privilegiada.

O agir arqueológico tem a função de criar elementos interlocutores ativos, abrindo janelas através dos sentidos, sendo criadores de percepções e conexões com o mundo. E entender, incluir, organizar, formar, computar significa aprender, tecem redes complexas e dinâmicas. Evidentemente, isso só se faz com o sucesso da gestão, da aprendizagem, das leituras das diferentes linguagens, caso contrário, tem-se uma arqueologia centrada no poder.

A gestão nos projetos de arqueologia, quando integradora de múltiplas dimensões do ser humano, é resultante de uma arqueologia reflexiva, que busca uma abordagem mais complexa da ciência arqueológica e amplia as possibilidades de repercussão, compreendida numa perspectiva local e global: a família, a escola, a comunidade, o trabalho, o país, etc., não uma dimensão de escravidão e serventia ao poder.

Por isso, a gestão nos projetos de arqueologia, a exemplo da educação defendida por Morin (2000, p.102-3), deve refletir o ato de ensinar e considera alguns pontos essenciais:

- fornecer uma cultura que permita distinguir, contextualizar, globalizar os problemas multidimensionais, globais e fundamentais, e dedicar-se a eles;

- preparar as mentes para responder aos desafios que a crescente complexidade dos problemas impõe ao conhecimento humano;

- preparar as mentes para enfrentar as incertezas que não param de aumentar, levando-as não somente a descobrirem a história incerta e aleatória do Universo, 
da vida, da humanidade, mas também promovendo nelas a inteligência estratégica e a aposta em um mundo melhor.

A prática reflexiva, a cultura, o envolvimento crítico e a complexidade são inteligências estratégicas, e estas são estratégias de extrema importância para o mundo, principalmente para os projetos de arqueologia. Nesse contexto, podem ocorrer transformações com colaborações mútuas e criatividade para que os arqueólogos possam criar autonomia de pensamento, abandonando o dogmatismo acadêmico. A gestão nos projetos de arqueologia deve permitir aos técnicos em arqueologia, aos estudantes e a todos os envolvidos nas pesquisas a capacidade de interpretar e reinterpretar a ciência arqueológica, dando-lhe novos significados, pois ensinar é instrumentalizar o sujeito a contestar, é instigar dúvidas, é estimular o pensar. Portanto, deve-se pensar numa ciência arqueológica propulsora e conscientizadora do homem. Para a obtenção desta arqueologia cabe aos projetos de arqueologia propiciar as condições mínimas à formação de profissionais que ultrapassem a etapa de decifração e que sejam capazes de refletir sobre a sua leitura e sobre a realidade que os cerca, conscientizando-se das possibilidades que Ihes são oferecidas ou negadas.

A atividade de interação nos projetos de arqueologia e de reflexão realizar-se-á à medida que houver projetos que permitam questionamentos, nos quais os profissionais de arqueologia puderem aprender corrigindo seus erros e não se condicionando a respostas prontas, certas e acabadas. Através da percepção e, conseqüentemente, do envolvimento intelectual e emocional ativo para a transformação social é que a arqueologia contribuirá para um mundo mais humano, responsável e justo. 



\section{REFERÊNCIAS}

ALEGRETTI, Isamara Della Favera; TITTONI, Jaqueline. Motivação. In CATTANI, Antonio David. Trabalho e Tecnologia: dicionário crítico. Petrópolis:Vozes, 1997.

ANTUNES, Paulo de Bessa. Direito ambiental. Rio de Janeiro: Lumen Juris, 1996.

BARRETO, Vicente de Paula (Coord.). Dicionário de Filosofia do Direito. São Leopoldo: Unisinos/Renovar, 2006.

BARON, Dan. Alfabetização cultural: a luta íntima por uma nova humanidade. SP: Alfarrábio, 2004.p 420.

BARROSO, Luis Roberto. A proteção do meio ambiente na Constituição Brasileira.In: Cadernos de Direito Constitucional e Ciência Política. São Paulo: ano 1, RT, p. 115-140, dez. 1992.

BASTOS, Rossano Lopes; BRUHNS Katianne; TEIXEIRA Adriana. A arqueologia na ótica institucional: IPHAN, contrato e sociedade. Erechim: Habilis, 2007.

BASTOS, Rossano Lopes. Preservação, arqueologia e representações sociais: uma proposta de arqueologia social para o brasil. Erechim: Habilis, 2007.

BASTOS, Rossano Lopes. Patrimônio arqueológico: impactos cumulativos, 2005.

BITTAR FILHO, Carlos Alberto. Tutela do meio ambiente: a legitimação ativa do cidadão brasileiro". São Paulo: RT, nº 698, p. 12-16, dez.1993.

BOBBIO, Norberto; MATTEUCCI, Nicola; PASQUINO, Gianfranco. Dicionário de política. Brasília: UNB, 1984, vol. 2.

BOFF, Leonardo. A águia e galinha: uma metáfora da condição humana. Petrópolis: Vozes, 1997.

BOURDIEU, Pierre. O poder simbólico. Trad.Fernando Tomaz. Rio de Janeiro. Bertrand,1989. p. 17- 58

BUENO, Marcos. Gestão pela qualidade total: ma estratégia administrativa. São Paulo: Mimeograpol, 2004. 
CAMPOS, Vicente Falconi. $\mathbf{O}$ aprendizado da gestão. Disponível em: www.indg.com.br . Acesso em 28 de fev. 2005.

CASTELLS, Manuel. A era da informação. Economia, sociedade e cultura. São Paulo: Paz e Terra, 1999, vol.3.

CHIAVENATO, Idalberto; SAPIRO, Arão. Planejamento stratégico fundamentos e aplicações. Rio de Janeiro: Elsevier , 2004.

CORREAA, Maria Baumgarten. Reestrutração produtiva. In CATTANI, Antonio David. Trabalho e tecnologia: dicionário crítico. Petrópolis: Vozes, 1997.

DAFT, Richard L. Administração.Trad. Robert Brian Taylor. São Paulo: Pioneira Thomson Leaning, 2005.

DALLARI, Dalmo de Abreu. Elementos da teoria geral do estado. São Paulo: Saraiva, 1978.

DEMO, Pedro. Participação é conquista: noções de política social participativa. São Paulo: Cortez, 1996.

DIAS, Adriana Schmidt. Um projeto para a arqueologia brasileira: breve histórico da implementação do Pronapa. In: Revista do CEPA. Santa cruz do Sul, v 19, março de 1995, p. 25 - 39.

DÓRIA, Carlos Alberto. A merencória luz do estado. São Paulo em Perspectiva, São Paulo: Fundação SEADE, 2001.

FARIAS, Paulo José Leite. Competência Federativa e proteção ambiental. Porto Alegre: Sergio Antonio Fabris, 1999.

FERNANDES, Ângela. A responsabilidade social e a contribuição das relações públicas. Comunicação apresentada ao GT de Relações Públicas, da INTERCOM - Sociedade Brasileira de Estudos Interdisciplinares da Comunicação, no XXIII Congresso Brasileiro de Ciências da Comunicação, realizado de 2 a 6 de setembro de 2000 na Universidade do Amazonas, Manaus AM.

FERREIRA, Leila da Costa. A questão ambiental: sustentabilidade e políticas públicas no Brasil. São Paulo: Bom Tempo, 1998, p. 25.

FLETA, Luis Solano. Fundamentos de las relaciones públicas, Madri: Editorial Sínteses, 1995.

FOGOLARI, Pedro Paulo Funari; Everson Paulo (Org.). Estudos de arqueologia histórica. Erechim / RS: Independente, 2005. v. 1.

FOGOLARI, Everson Paulo. Arqueologia preventiva na área de influência da PCH Antoninha - São Joaquim/SC. 2004. 
Arqueologia preventiva na área de influência da da PCH Gamba - São Joaquim/SC. 2004.

Arqueologia preventiva na área de influência da $\mathrm{PCH}$ Malacara - São Joaquim/SC. 2004.

Arqueologia Preventiva na área de influência da PCH São Mateus - São Joaquim/SC. 2004.

As novas estratégias competitivas e a reestruturação no sistema produtivo.Perspectiva. , Erechim: Universidade Regional Integrada do Alto Uruguai e das Missões - URI: março de 1995.

O processo de terceirização na indústria brasileira. Erechim: Perspectiva, Universidade Regional Integrada do Alto Uruguai e das Missões URI, nº 67, 1995.

. Reestruturação produtiva: implicações nas relações de trabalho. Erechim: URI / Edelbra. 1998.

FROSSARD, Denise. Disponível no site: www.denisefrossard.com.br/ palestras/responsabilidade.Acesso em 25/nov. 2006.

FUNARI, Pedro P. Arqueologia. São Paulo: Contexto. 2004.

FUNDAP. Gestão estratégica - Programa de Desenvolvimento Gerencial. São Paulo:Fundap, 2004.

FUTAMI, Andre H.; VALENTINA; Luiz Veriano O. Dalla; POSSAMAI,Osmar. Um modelo de gestão do conhecimento para a melhoria de qualidade do produto. Florianópolis: Mimeografado, 2004.

GARAY, Ângela. Gestão. In: CATTANI, Antonio David. Trabalho e tecnologia: dicionário crítico. Petrópolis: Vozes, 1997.

GODET, Michel. A caixa de ferramentas da prospectiva estratégica. Lisboa: Caderno do CEPES, 2000.

GODET, Michel. Manual de prospectiva estratégica: a antecipação da ação. Lisboa:Publicações Dom Quixote, 1993.

GUIMARÃES, Roberto P. Da oposição entre desenvolvimento e meio ambiente ao desenvolvimento sustentável: uma perspectiva do sul". In: FONSECA Jr, Gelson; CASTRO, Sérgio H. N. Temas de Política Externa Brasileira II. São Paulo: Paz e Terra, 1994, pp. 201-232.

HARVEY, David. A Condição pós-moderna. 2. ed. São Paulo: Loyola, 1993.

HOLANDA, Aurélio Buarque de, Novo Dicionário Brasileiro da Língua Portuguesa. São Paulo: Melhoramentos, 2003 
HORTA, M. L. P; GRUMBERG, E. \& MONTEIRO, A. Q. Guia básico de educação patrimonial. IPHAN / Museu Imperial. Brasília, 1999.

KAPLAN, Robert S.; NORTON, David P. A estratégia em ação. Rio de Janeiro: Campus, 1997.

HUERTAS, Franco. Entrevista com Matus - O método PES. São Paulo: Fundap, 1996.

IPHAN. Portaria $n^{\circ} 230$ de 17 de dezembro de 2002. Regulamenta a arqueologia no Licenciamento Ambiental

KUHN, Thomas S. A estrutura das revoluções científicas. $3^{\text {a }}$ ed. 1995.

LARANGEIRA, Sonia M.G. Fordismo. In CATTANI, Antonio David. Trabalho e Tecnologia: dicionário crítico. Petrópolis: Vozes, 1997.

Programa de qualidade total. In: CATTANI, Antonio David. Trabalho e tecnologia: dicionário crítico. Petrópolis: Vozes, 1997.

BRASIL. Lei federal n 3.924 de 26 de julho de 1961.

LEIS, Héctor R. Ambientalismo: um projeto realista - utópico para a política Mundial. In: VIOLA, E. J.; LEIS, H.R.; SCHERER-WARREN, I; GUIVANT, J.S.; IEIRA, P.F.; KRISCHKE, P.J..Meio ambiente, desenvolvimento e cidadania: desafio para as Ciências Sociais. São Paulo: Cortez; Florianopólis: Universidade Federal de Santa Catarina, 1995. p. 15-42.

LEMOS, Carlos A. C. O que é patrimônio histórico? São Paulo: Brasiliense, 1981.

LONDERO, Maria Alice Antonello.O estudo de impacto ambiental no direito brasileiro e argentino. Dissertação (Mestrado em ). Universidade Federal de Santa Maria, Santa Maria, 1999.

MACHADO, Paulo Affonso Leme. Direito ambiental brasileiro. São Paulo: Malheiros, 1998.

McCORMICK, John. Rumo ao Paraíso. A história do movimento ambientalista. Rio de Janeiro: Relume-Dumará, 1992.

MALHOTRA,Y. What is knowledge management? 1998. Disponível em: www.brint.com/km. Acesso em: 28/fev/2005.

MATTIOLI, Maria Cristina, Responsabilidade social da empresa e comunicação. www.mundojuridico.adv.br

MIRRA, Álvaro Luiz Valery. A participação popular na proteção do meio ambiente. In: A legislação sobre meio ambiente e suas tendências, Câmara Americana de Comércio para o Brasil, em São Paulo, 4 de dezembro de 1989, p. 1. 
MARCIAL, Elaine Coutinho; GRUMBACH, Raul dos Santos. Cenários prospectivos: como construir um futuro melhor. Rio de Janeiro: FGV, 2002.

MARCOVITCH, Jacques; RADOSEVICH, Raymond. Planejamento estratégico nas organizações estruturadas por projeto. Revista de Administração, FEA/ USP, vol. 13, n. 2,abr./jun. 1978.

MATUS, Carlos. Estratégias políticas: chipanzé, Maquiavel e Ghandi. Tradução de Giselda Barroso Sauve ur. São Paulo: FUNDAP, 199654

MEIRELLES, Helly Lopes. Mandado de egurança: ação popular, ação civil pública, mandado de injunção, "habeas data". São Paulo: Revista dos Tribunais, 1989.

MIAILLE, Michel. Representação, cidadania e exclusão social. In: VENTURA, América Latina: Cidadania, Desenvolvimento e Estado. Org. Ventura. Deisy de Freitas Lima. Porto Alegre: Livraria do Advogado, 1996, p. 155-166.

MILARÉ, Édis. A participação comunitária na tutela do ambiente. 1992. In: Revista Forense. Rio de Janeiro: Forense, vol. 317, p. 79-87.

. Direito do Ambiente: doutrina, prática, jurisprudência, glossário. São Paulo: Ed. RT, 2000.

. Legislação ambiental e participação comunitária". São Paulo:RT, fev.1992, p. 48-59.

MILDER, Saul Eduardo Seiguer. Caçadores coletores: a problemática arqueológica e ambiental sobre os primeiros povoadores do Rio Grande do Sul. Revista do CEPA, V.23 No 30, p. 7-56 jul./dez., Santa Cruz do Sul, 1999.

MIRANDA FILHO, Nildo Leite. Disponível em: www.guiarh.com.br, Acesso em: 28 fev. 2005.

MORAIS, D. Arqueologia da Arquitetura: Estação Ferroviária de Piraju - ensaio de arqueologia da arquitetura de Ramos de Azevedo.Erechim: Habilis, 2007.

MORAIS, J. L. Reflexões acerca da arqueologia preventiva In:MORI, V.H.et al. Patrimônio: atualizando o debate. São Paulo: IPHAN, 2007.

Perspectivas geoambientais da arqueologia do Paranapanema paulista. Tese de Livre-Docência. São Paulo: Museu de Arqueologia e Etnologia da Universidade de São Paulo, 1999.

A arqueologia e o fator geo. Revista do Museu de Arqueologia e Etnologia, v.9, p.3-22, 1999.

Tópicos de arqueologia da paisagem. Revista do Museu de

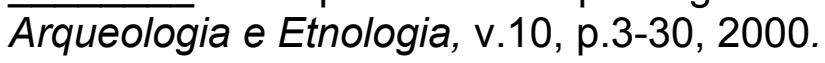


Arqueologia da Região Sudeste. Revista USP, v.44, p.194-217, 2000.

A arqueologia e o turismo. In FUNARI, P. P.; J. PINSKY (Org) Turismo e Patrimônio Cultural: São Paulo: Contexto, 2001, p.95-103.

Arqueologias do Brasil. In: $2^{\circ}$ WORKSHOP ARQUEOLÓGICO DE XINGÓ:21-26. Canindé do São Francisco: MAX-UFS, 2002. Anais.

MORAIS, J. L.; D. MORAIS.Arqueologia da paisagem urbana: a cidade na perspectiva patrimonial. Revista de Arqueologia Americana, v.20, p.81-110, 2001.

MORAIS, J. L.; H. A. MOURÃO; A. Ch. VAZ.O direito ambiental e a arqueologia de impacto. In: SILVA, B. C. (Org) Direito ambiental - enfoques variados,. São Paulo: Lemos \& Cruz, 2004, p. 357-385.

MORIN, Edgar. A cabeça bem feita: repensar a reforma, reformar o pensamento. Tradução: Eloá Jacobina. Rio de Janeiro: Bertrand Brasil, 2000, 128p.

MOURÃO. Henrique Augusto. Patrimônio arqueológico: um bem difuso subsídios do direito ambiental brasileiro à participação das associações civis na promoção e proteção do patrimônio arqueológico. (Dissertação em Arqueologia), 2007.

MOTTA, Paulo Roberto. Gerenciando o futuro: a conquista da visão estratégica. In:Gestão Contemporânea: a ciência e a arte de ser dirigente. Rio de Janeiro: Record, 1991.

MURRAY, $P$. The profusion and confusion of knowledge management terminology. In: KNOWLEDGE MANAGEMENT CONSORTIUM BECHMARKING STUDY. Final Report, 1996.

OLIVEIRA, Djalma de P. R. Planejamento de desenvolvimento gerencial. São Paulo: Fundap, 2004.

REALE, Miguel. Lições preliminares de direito. São Paulo: Saraiva,2002.

REBELLO FILHO, Wanderley; BERNARDO, Christianne. Guia prático de direito ambiental. Rio de Janeiro: Lumen Juris, 1998.

SANTOS, Cecília Rodrigues dos. Novas fronteiras e novos pactos para o patrimônio cultural. Guia Cultural do Estado de São Paulo. 2001.

SANTOS, Márcia Walquíria Batista dos. Meio Ambiente na Atualidade e o Exercício da Cidadania. Revista dos Tribunais, vol. 690. São Paulo: RT, v. 690, abril de 1993, p. 282-286.

SILVA, J. A. Direito ambiental constitucional. São Paulo: Malheiros, 1998.

SILVA, Marcos A. da. Patrimônios históricos. In: história: o prazer em ensino e pesquisa. São Paulo: Brasiliense, 1995. 
SVEIBY, K.E. A nova riqueza das organizações. Rio de Janeiro: Campus, 1998.

TAAN, Mauricio. Modelos em arqueologia. In: Atas do Simpósio sobre Política Nacional do Meio Ambiente e Patrimônio Cultural, Goiânia: UCG, 1996, p. 43.

TRINDADE, Antônio Augusto Cançado. Direitos humanos e meio ambiente: paralelo dos sistemas de proteção internacional. Porto Alegre: Sergio Antonio Fabris, 1990.

VIEIRA, Liszt. Cidadania e globalização. Rio de Janeiro: Record, 1998.

VIOLA, E. J.. O movimento ambientalista no Brasil (1971-1981): da denúncia e conscientização pública para a institucionalização e 0 desenvolvimento sustentável. In: GOLDENBERG, Miriam (Org.) Ecologia, ciência e política. Organizadora. Rio de Janeiro: Revan, 1990, p. 49-75.

ZARANKIN, Andrés. Paredes que domesticam: arqueologia da arquitetura escolar capitalista - O caso Buenos Aires. UNICAMP/ FAPESP. Campinas, 2002.

WRIGHT, James et al. Projeto FLORAM: missão, estratégias e planos de ação. In: Projeto FLORAM: uma plataforma. São Paulo: Estudos Avançados, v.4, n.09,p. 301, p. 120-148, maio/ago, 1990.

WRIGHT, James; PEREIRA, Ana M. Levantamento e análise dos métodos de elaboração e utilização de cenários nas empresas brasileiras. Apresentado no VII SEMEAD - Seminários em Administração. São Paulo: FEA-USP, 2004. 